\title{
DURABILITY EVALUATION AND PRODUCTION OF MANUFACTURED AGGREGATES FROM COAL COMBUSTION BY-PRODUCTS
}

Final Report

October 1, 2000 through February 28, 2005

M. M. $\mathbf{W u} \mathbf{u}^{*}$

February 2005

Cooperative Agreement No. DE-FC26-00NT40910

\author{
CONSOL Energy \\ Research \& Development \\ 4000 Brownsville Road \\ South Park, PA 15129 \\ (412) 854-6708 \\ *Current Address: \\ Universal Aggregates, LLC \\ 300 Bursca Drive, Suite 303 \\ Bridgeville, PA 15017
}

(412) 914-1146 


\section{DISCLAIMER}

This report was prepared as an account of work sponsored by an agency of the United States Government. Neither the United States Government nor any agency thereof, nor any of their employees, makes any warranty, express or implied, or assumes any legal liability or responsibility for the accuracy, completeness, or usefulness of any information, apparatus, product, or process disclosed, or represents that its use would not infringe private owned rights. Reference herein to any specific commercial product, process, or serve by trade name, trademark, manufacturer, or otherwise does not necessarily constitute or imply its endorsement, recommendation, or favoring by the United States Government or any agency thereof. The views and opinions of authors expressed herein do not necessarily state or reflect those of the United States Government or any agency thereof. 


\begin{abstract}
Under the cooperative agreement with DOE, the Research and Development Department of CONSOL Energy (CONSOL R\&D), teamed with Universal Aggregates, LLC, to conduct a systematic study of the durability of aggregates manufactured using a variety of flue gas desulfurization (FGD), fluidized-bed combustion (FBC) and fly ash specimens with different chemical and physical properties and under different freeze/thaw, wet/dry and long-term natural weathering conditions. The objectives of the study are to establish the relationships among the durability and characteristics of FGD material, FBC ash and fly ash, and to identify the causes of durability problems, and, ultimately, to increase the utilization of FGD material, FBC ash and fly ash as a construction material. Manufactured aggregates made from FGD material, FBC ash and fly ash, and products made from those manufactured aggregates were used in the study. The project is divided into the following activities: sample collection and characterization; characterization and preparation of manufactured aggregates; determination of durability characteristics of manufactured aggregates; preparation and determination of durability characteristics of manufactured aggregate products; and data evaluation and reporting.
\end{abstract}




\section{LIST OF ACRONYMS}

AASHTO - American Association of State Highway and Transportation Officials AEP - American Electric Power

ASTM - ASTM International (formerly American Society for Testing and Materials) $\mathrm{CBR}$ - California bearing resistance

CCB - coal combustion by-product

CCP - coal combustion product (same as CCB)

FBC - fluidized-bed combustion/combustor

FGD - flue gas desulfurization

GPCO - Georgia Power Company

JEA - Jacksonville Electric Authority

LOI - loss on iginition

OCDO - Ohio Coal Development Office

PTM - Pennsylvania testing method

PG\&E - Pacific Gas \& Electric Company

SDA - spray dryer ash/absorber

SEM - scanning electron microscope/microscopy

SSD - saturated-surface-dry

TGA - thermogravimetric analysis

TNP - Texas-New Mexico Power Company

XRD - X-ray diffraction 


\section{TABLE OF CONTENTS}

DISCLAIMER

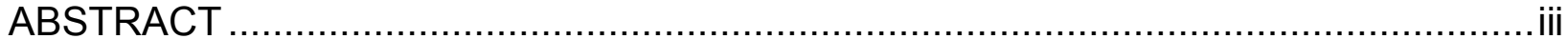

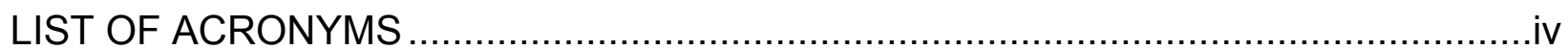

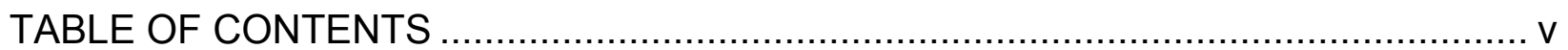

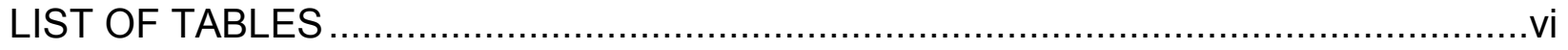

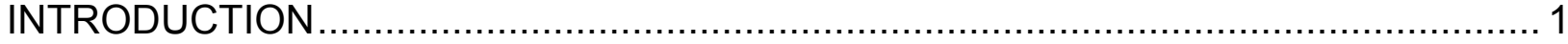

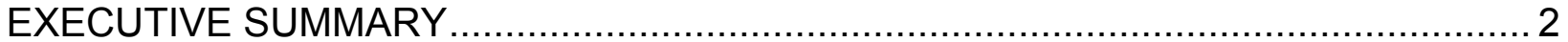

Sample Collection and Characterization ....................................................... 2

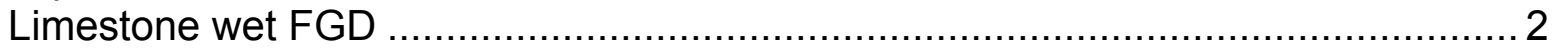

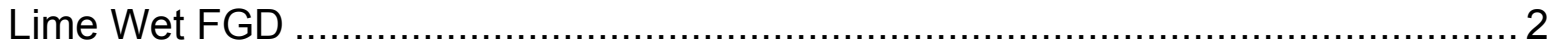

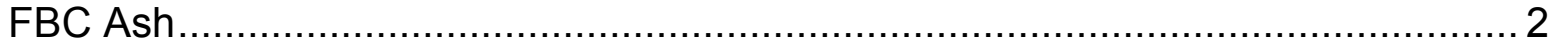

Pulverized Coal Fly Ash .......................................................................... 2

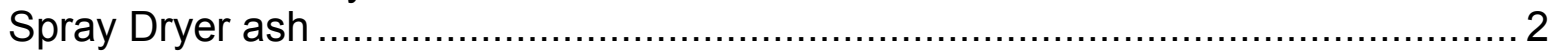

Preparation and Characteristics of Manufactured Aggregates ................................ 3

Determination of Durability Characteristics of Manufactured Aggregates .................... 3

Durability Characteristics of Manufactured Aggregate Products.............................. 5

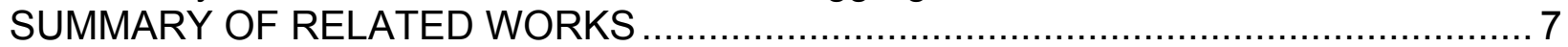

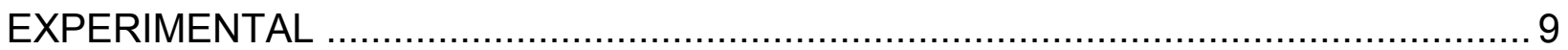

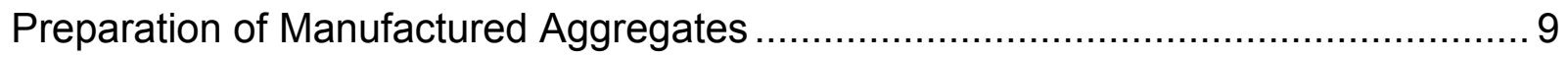

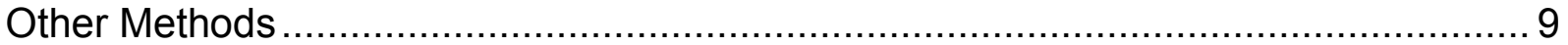

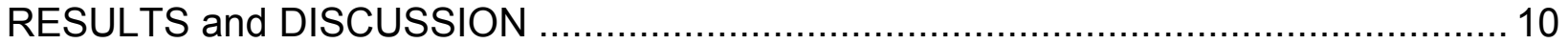

Sample Collections and Characterization ...................................................... 10

Preparation and Characterization of Manufactured Aggregates ............................. 16

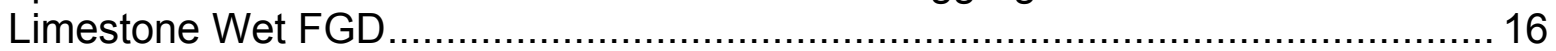

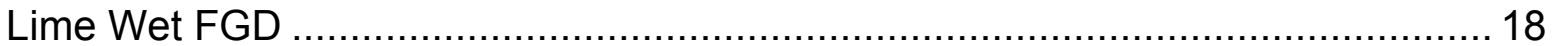

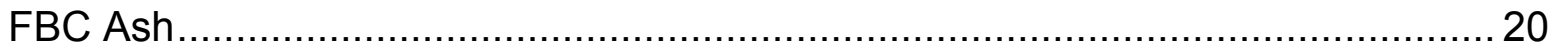

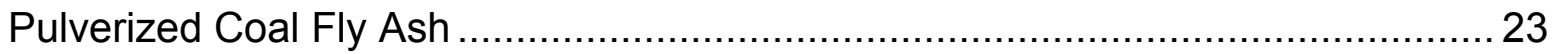

Spray Dryer Ash................................................................................. 23

Determinations of Durability Characteristics of Manufactured Aggregates ............... 38

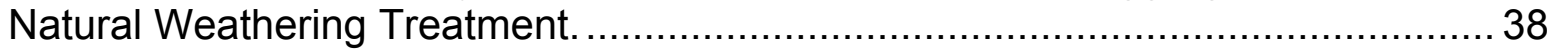

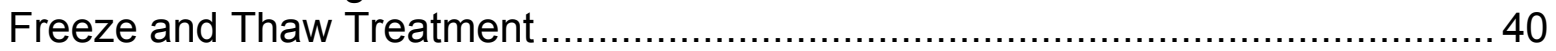

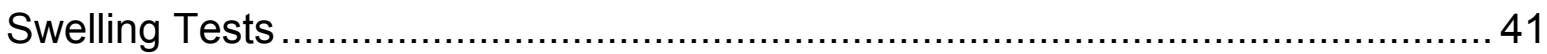

Determinations of Durability Characteristics of Manufactured Aggregate Products... 43

Wet/Dry Cycles Treatment. ............................................................................ 43

Freeze/Thaw Treatment without Immersion in Water.................................... 46

Freeze/Thaw Treatment with Immersion in Water...........................................5 51

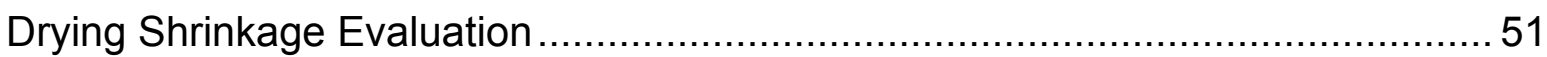

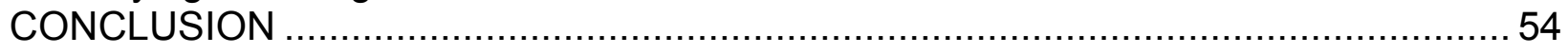

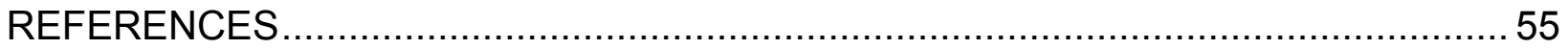

LIST OF APPENDICES

Appendix A. Swelling Tests - Geotechnics Laboratory

Appendix B. Swelling Tests - University of Kentucky Laboratory 


\section{LIST OF TABLES}

Table A. Properties and Durability Characteristics of Manufactured Aggregates ........... 5

Table B. Durability Characteristics of Manufactured Aggregate Products ...................... 6

Table 1-A. Analyses of Limestone Wet FGD Materials ......................................... 11

Table 1-B. Analyses of Lime Wet FGD Materials .................................................. 12

Table 1-C-1. Analyses of FBC Ash (From Low and High Sulfur Coals) ...................... 13

Table 1-C-2. Analyses of FBC Ash (From Waste Coal) ........................................... 14

Table 1-D. Analyses of Pulverized Coal Fly Ash ....................................................... 15

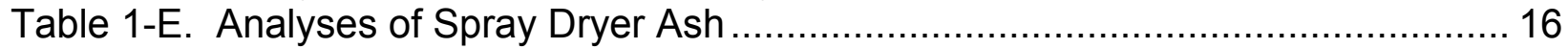

Table 2-A-1. Test Conditions and Properties of Pelletized Products Made with Fixated Wet Limestone Materials from Reliant Energy Limestone Station in Texas (Limestone Wet FGD with Class C Fly Ash) ......................................... 25

Table 2-A-2. Test Conditions and Properties of Pelletized Products Made with Fixated Limestone FGD Materials from Lakeland Mclntosh Station in Florida (Limestone Wet FGD with Class F Fly Ash)................................................ 26

Table 2-B-1. Test Conditions and Properties of Pelletized Products Made with Fixated Wet Lime FGD Materials from Reliant Energy's Elrama Station in Pennsylvania (Lime Wet FGD with High LOI Fly Ash) ......................................... 27

Table 2-B-2. Test Conditions and Properties of Pelletized Products Made with Fixated FGD Materials from AEP Gavin Station in Ohio (Lime Wet FGD with Low LOI Fly Ash).....

Table 2-B-3. Test Conditions and Properties of Pelletized Products Made with Fixated Wet Lime FGD Materials from AEP Conesville Station in Ohio (Lime Wet FGD with High and Low LOI Fly Ash)

Table 2-C-1. Test Conditions and Properties of Pelletized Products Made with Low Sulfur FBC Ash from New Mexico Power TNP One Station (FBC Ash from Low Sulfur Texas Lignite) .............................................................................. 30

Table 2-C-2. Test Conditions and Properties of Pelletized Products Made with Low Sulfur FBC Ash from AES Guayama Station in Puerto Rico (FBC Ash from Low Sulfur Coal).

Table 2-C-3. Test Conditions and Properties of Pelletized and Extruded Products Made with Low Sulfur FBC Ash from Tractebel Power Red Hills Station in Mississippi (FBC Ash from Low Sulfur Lignite)

Table 2-C-4. Test Conditions and Properties of Pelletized and Extruded Products Made with High Sulfur FBC Ash from JEA Northside Station in Florida (FBC Ash from High Sulfur Coal and Coke).

Table 2-C-5. Test Conditions and Properties of Pelletized Products Made with Waste Coal FBC Ash from PG\&E Northampton Station in Pennsylvania (FBC

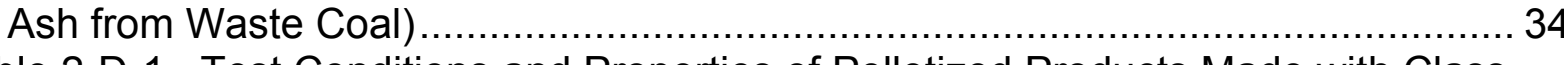

Table 2-D-1. Test Conditions and Properties of Pelletized Products Made with Class F Fly Ash from JEA Seminole Station in Florida and Class C Fly Ash from GPCO Scherer Station in Georgia (Class F and Class C Fly Ash). 
Table 2-E-1. Test Conditions and Properties of Pelletized and Extruded Products Made with SDA Containing Class F Fly Ash from Birchwood Power Station in Virginia (Spray Dryer Ash with Class F Fly Ash)....

Table 2-E-2. Test Conditions and Properties of Pelletized Products Made with SDA Containing Class C Fly Ash from Sunflower Power Holcomb Station in Kansas (Spray Dryer Ash with Class C Fly Ash)

Table 3-A. Swell Properties of Manufactured Aggregates in the Elevated Temperature Test ....

Table 3-B. Swell Properties of Manufactured Aggregates in the Ambient Temperature Tests (a) ......................................................................... 42

Table 4-A-1. The Effects of Wet/Dry Treatment on Durability of Test Specimens A and B (Limestone Wet FGD with Class F Fly Ash) ......................................... 44

Table 4-A-2. The Effects of Wet/Dry Treatment on Durability of Test Specimens A and B (Lime Wet FGD with High and Low LOI Fly Ash).....

Table 4-A-3. The Effects of Wet/Dry Treatment on Durability of Test Specimens A and B (Spray Dryer Ash with Class F fly ash) ............................................... 45

Table 4-B-1. The Effects of Wet/Dry Treatment on Durability of Test Specimens and B FROM MIX DESIGN 1 (Lime Wet FGD with High and Low LOI Fly Ash)...

Table 4-B-2. The Effects of Wet/Dry Treatment on Durability of Test Specimens A and B FROM MIX DESIGN 2 (Lime Wet FGD with High and Low LOI Fly Ash) ...... 46

Table 4-C-1. The Effects of Wet/Dry Treatment on Durability of Test Specimens A and B (Limestone Wet FGD with Class F Fly Ash) ........................................ 47

Table 4-C-2. The Effects of Wet/Dry Treatment on Durability of Test Specimens A and B (Lime Wet FGD with High and Low LOI Fly Ash).....................................4 47

Table 4-C-3. The Effects of Wet/Dry Treatment on Durability of Test Specimens A and B (Spray Dryer Ash with Class F Fly Ash) .............................................. 48

Table 4-D-1. The Effects of Freeze/Thaw Treatment on Durability of Test Specimens A and B from Mix Design 1 (Lime Wet FGD with High and Low LOI Fly Ash) .........48 48

Table 4-D-2. The Effects of Freeze/Thaw Treatment on Durability of Test Specimens A and B from Mix Design 2 (Lime Wet FGD with High and Low LOI Fly Ash).

Table 4-E-1 The Effects of Freeze/Thaw Treatment on Durability of Test Specimens $A$ and B of Drill Core Samples from Asphalt Pavement in Warren, Ohio ....

Table 4-E-2 The Effects of Freeze/Thaw Treatment on Durability of Test Specimens $A$ and B of Drill Core samples from Asphalt Pavement in South Park, Pennsylvania. ............................................................................... 50

Table 4-E-3 The Effects of Freeze/Thaw Treatment on Durability of Test Specimens A and B of Drill Core Samples from Asphalt Pavement in Nokomis, Florida........... 50 Table 4-F-1 The Effect of Freeze/Thaw Treatment on Durability of CMU Test Specimens

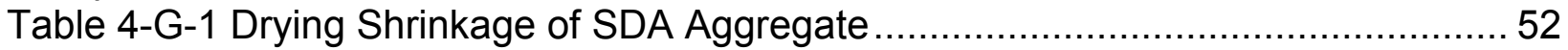

Table 4-H-1 Drying Shrinkage of FBC Aggregate 53 


\section{INTRODUCTION}

FGD material, FBC ash and fly ash have useful engineering properties that make them attractive for high-volume use in construction. However, only about $19 \%$ of the FGD material produced in the United State is utilized. About $70 \%$ of utilized FGD material is production of gypsum from forced-oxidation wet scrubber systems for wallboard production. The wallboard market for gypsum is near saturation. Fly ash is the most utilized coal combustion by-product. Installation of NOx control technology (low NOx burners and SCR) can affect the utilization of fly ash. Many factors impede the utilization of FGD material and fly ash. One major concern for construction-related utilization is the durability. FBC ash and some dry FGD by-products were reported to have expansive properties, which cause durability problems in utilization. In contrast, FGD sludge, fixated with fly ash and lime, has been used commercially in road construction, flowable fill and structural fill for years. FGD material includes dry FGD by-product and fixated FGD sludge; FBC ash is often considered as an FGD material. FGD material and FBC ash generated from different processes have distinctly different characteristics. Installation of low NOx burners for NOx control often increases fly ash LOI that causes durability problems for use of fly ash in concrete production. Therefore, it is important to conduct a systematic study of the durability using a variety of FGD and fly ash specimens with different chemical and physical properties and under different freeze/thaw, wet/dry and long-term natural weathering conditions. The objectives of the study are to establish the relationships among durability and characteristics of FGD material, FBC ash and fly ash, to identify the causes of durability problems and, ultimately, to increase the utilization of FGD material, FBC ash and fly ash as a construction material. Manufactured aggregates made from FGD material, FBC ash and fly ash, and products made from manufactured aggregates were used in the study.

Manufactured aggregates and products made from manufactured aggregates are suitable for use in the durability study. Manufactured aggregates usually are small with a diameter of less than 1". The effects of freeze/thaw, wet/dry, and long-term natural weathering on physical properties and structural integrity are relatively easy to identify and correlate with chemical and mineralogical changes in the manufactured aggregates. The results of this study will be generally applicable to the durability issues for the high volume use of coal combustion by-products (FGD material, fly ash and FBC ash) in construction application. In addition, the effects of mix components and preparation method on the durability can be readily evaluated with manufactured aggregates.

Production of manufactured aggregate has potential to substantially expand markets for the utilization of FGD material, FBC ash and fly ash. It could also be a cost effective way for preventing and reducing utilization problems associated with implementation of NOx control technologies at power plants. As a partial replacement of natural aggregate, the consumption of manufactured aggregate is not limited by market volume, seasonal demand, problems in handling, transportation and storage as many other utilization options (e. g., structural fill). 


\section{EXECUTIVE SUMMARY}

This study is divided into four main tasks: 1) sample collection and characterization; 2) preparation and characterization of manufactured aggregates; 3) determination of durability characteristics of manufactured aggregates; and 4) preparation and determination of durability characteristics of manufactured aggregate products. The summary and conclusions of each of these follow.

\section{Sample Collection and Characterization}

Coal combustion by-products (CCBs) used in this study were collected from different utility power plants. The CCBs are divided into lime and limestone wet FGD materials, FBC ash, pulverized coal fly ash and spray dryer ash. The types of CCBs and sources of the CCBs are listed below:

\section{Limestone wet FGD}

1. Limestone wet FGD fixated with Class $C$ fly ash

Reliant Energy Limestone Station in Texas

2. Limestone wet FGD fixated with Class F fly ash Lakeland Mclntosh Station in Florida

\section{Lime Wet FGD}

3. Lime wet FGD fixated with high LOI fly ash

Reliant Energy Elrama Station in Pennsylvania

4. Lime wet FGD fixated with low LOI fly ash AEP Gavin Station in Ohio

5. Lime wet FGD fixated with high and low fly ash AEP Conesville Station in Ohio

\section{FBC Ash}

6. FBC ash from low-sulfur coal and lignite

New Mexico Power TNP One Station in Texas (low-sulfur lignite)

AES Guayama Station in Puerto Rico (low-sulfur coal)

Tractebel Power Red Hills Station in Mississippi (low-sulfur lignite)

7. FBC ash from high-sulfur coal and petcoke

JEA NorthsideStation in Florida

8. FBC ash from waste coal (or gob)

PG\&E Northampton Station in Pennsylvania

\section{Pulverized Coal Fly Ash}

9. Class C fly ash

GPCO Scherer Station in Georgia

10. Class $\mathrm{F}$ fly ash

JEA Seminole Station in Florida

First Energy Sammis Station in Pennsylvania

\section{Spray Dryer ash}

11. Spray dryer ash with Class F fly ash

Birchwood Power Station in Virginia 
12. Spray dryer ash with Class $C$ fly ash

Sunflower Power Holocomb Station in Kansas

All CCBs were characterized for moisture contents, ultimate analyses and major elemental composition. Relevant chemical compositions and physical properties including LOI (loss on ignition), sulfur forms, solid concentration, specific gravity, lime index, and particle size distribution were also characterized for comparison.

\section{Preparation and Characteristics of Manufactured Aggregates}

Manufactured aggregates were produced with the above CCBs as feed materials in a three-step process consisting of mixing, agglomerating (pelletizing or extruding) and curing. As shown in Table A, manufactured aggregates produced from different feed materials are separated into lightweight aggregates and road aggregates. Lightweight aggregates include those produced from limestone wet FGD (fixated with Class F fly ash), lime wet FGD (fixated with high LOI fly ash and with low and high LOI fly ash), FBC ash (from low-sulfur coal, high-sulfur coal/petcoke and waste coal) and spray dryer ash (with Class $\mathrm{F}$ fly ash). Lightweight aggregates have maximum dry unit weights of $65{\mathrm{lb} / \mathrm{ft}^{3}}^{3}$ (ASTM C331 lightweight aggregate specification)) and have potential for use in production of lightweight or medium-weight concrete masonry units (CMU). Road aggregates include those produced from limestone wet FGD (fixated with Class C fly ash), lime wet FGD (fixated with low LOI fly ash), fly ash (Class C and Class F) and spray dryer ash (with Class C fly ash). Road aggregates have dry unit weights of 65 $\mathrm{lb} / \mathrm{ft}^{3}$ or higher and have potential for use in highway construction. Several lightweight aggregates listed in Table A were produced in the pilot plant and used in CMU block plant production demonstration. The lightweight aggregates include those made from limestone wet FGD material (fixated with Class F fly ash), lime wet FGD material (fixated with low and high LOI fly ash) and spray dryer ash (with Class F fly ash). Road aggregate made from lime wet FGD material (fixated with low LOI fly ash) was produced from the pilot plant and used in highway construction demonstration. These demonstration projects are discussed below in the Section, entitled "Summary of Related Work". Selected aggregates with different properties were used in the determination of durability characteristics of manufactured aggregates. Test specimens of aggregate products from the demonstration projects were used in the determination of durability characteristics of manufactured aggregate products.

\section{Determination of Durability Characteristics of Manufactured Aggregates}

Selected aggregates produced above were used in the determination of durability characteristics of manufactured aggregates. The selected aggregates include those produced from limestone wet FGD materials (fixated with Class $C$ and Class F fly ash), lime wet FGD materials (fixated with low and high LOI fly ash), FBC ash (from low-sulfur coal and from high-sulfur coal/petcoke) and spray dryer ash (with Class $\mathrm{C}$ and Class $\mathrm{F}$ fly ash). The swelling properties upon wetting and the effects of natural weathering and freeze/thaw cycles treatments on properties of manufactured aggregates were determined for comparison. The swelling properties and durability comparison of aggregates are summarized in Table A. Test results are discussed below. 
1. Road aggregate made from fixated wet FGD material with Class $C$ fly ash is more durable than lightweight aggregate made with Class $\mathrm{F}$ fly ash, based on freeze/thaw cycles treatments. The higher durability could be related to reactivity of Class $\mathrm{C}$ fly ash and higher unit weight (or density) of the aggregate. High durability, especially freeze/thaw resistance, is more important for road aggregate in highway application than for lightweight aggregate in CMU application.

2. Lightweight Aggregate made with FBC ash from low-sulfur coal is more durable than that made with FBC ash from a blend of high-sulfur coal and petcoke, based on the natural weathering study. The poor durability of high-sulfur FBC ash could be related to continuous slow hydration of quick lime and anhydrite in the ash upon wetting. Addition of pulverized coal fly ash can improve durability of aggregate made with FBC ash from high-sulfur coal and petcoke.

3. Durability of aggregate made from spray dryer ash with Class $C$ fly ash can be improved with increase in mix time, based on the natural weathering study. The improvement could be related to increased hydration of quick lime, anhydrite and others with increase in mix time.

4. Aggregate made from spray dryer ash with Class F fly ash had good durability based on freeze/thaw cycles treatment. Addition of cement did not improve aggregate durability.

5. Aggregates, made from limestone wet FGD material (fixated with Class $\mathrm{F}$ fly ash), FBC ash (from low-sulfur coal) and spray dryer ash (with Class F fly ash), had little swelling upon wetting. In comparison, aggregate made from FBC ash (from a blend of high-sulfur coal and coke) had high swelling upon wetting. The high swelling is related to the continuous hydration of quick lime and anhydrite upon wetting. Both hydration reactions can cause expansion (or swelling). 
Table A. Properties and Durability Characteristics of Manufactured Aggregates

\begin{tabular}{|l|c|c|}
\hline Feed Materials for Aggregate Production & Lightweight Aggregate & Road Aggregate \\
\hline $\begin{array}{l}\text { Limestone Wet FGD } \\
\text { Fixated with Class C fly ash } \\
\text { Fixated with Class F fly ash }\end{array}$ & $\times(\mathrm{b})$ & $\times(\mathrm{a})$ \\
\hline $\begin{array}{l}\text { Lime Wet FGD } \\
\text { Fixated with low LOI fly ash } \\
\text { Fixated with high LOI fly ash } \\
\text { Fixated with low and high LOI fly ash }\end{array}$ & $\times$ & $\times(\mathrm{a})$ \\
\hline $\begin{array}{l}\text { FBC Ash } \\
\text { Low-sulfur coals }\end{array}$ & $\times$ & \\
$\begin{array}{l}\text { High-sulfur coal/petcoke } \\
\text { Waste coal (gob) }\end{array}$ & $\times(\mathrm{b})$ & \\
\hline $\begin{array}{l}\text { Fly Ash } \\
\text { Class C fly ash } \\
\text { Class F fly ash }\end{array}$ & & \\
\hline $\begin{array}{l}\text { Spray Dryer Ash } \\
\text { With Class C fly ash } \\
\text { With Class F fly ash }\end{array}$ & & \\
\hline
\end{tabular}

(a) Aggregate with higher durability and crush strength

(b) Aggregate with little swell upon wetting

(c) Aggregate with high swell upon wetting

(d) Aggregate with lower durability and higher crush strength. Durability improved with pulverized coal fly ash addition

(e) Aggregate with higher crush strength. Durability improved with increasing mix time

(f) Aggregate with good durability with and without cement addition

\section{Durability Characteristics of Manufactured Aggregate Products}

Test specimens were prepared from concrete masonry units (CMU), cement concrete and asphalt concrete for the durability study. CMU were made with manufactured lightweight aggregates from limestone wet FGD material (fixated with Class F fly ash), lime wet FGD material (fixated with low and high LOI Class F fly ash) and spray dryer ash (with Class $\mathrm{F}$ fly ash) in field demonstrations. Cement concrete was made with manufactured lightweight aggregate from lime wet FGD material (fixated with low and high LOI Class F fly ash) in the qualification test for use in lightweight structural concrete. Asphalt concrete was made with road aggregate from lime wet FGD material (fixated with low LOI fly ash) in a field demonstration. The effects of wet/dry and freeze/thaw treatments on properties of test specimens were determined by monitoring dimension (length, width and height) and weight changes upon treatments. The comparison of durability characteristics is summarized in Table B. "High", "medium," and "low" listed in the table represent different levels of wet/dry and freeze/thaw resistance. Test results are discussed below. 
1. CMU and cement concrete test specimens made with manufactured lightweight aggregates all had high wet/dry resistance after 50 cycles of treatments. Little dimension and weight changes were observed during treatments. The test specimens were immersed in water during the wet cycle treatment. This simulated the extreme conditions of wet/dry cycles in applications of $\mathrm{CMU}$ and cement concrete.

2. CMU test specimens made with manufactured lightweight aggregates from either limestone wet FGD materials or spray dryer ash had high freeze/thaw resistance after 50 cycles of treatments. In comparison, CMU made with manufactured lightweight aggregate from lime wet FGD materials had medium freeze/thaw resistance. Both cement and asphalt concrete test specimens made with manufactured aggregates from lime wet FGD materials had high freeze/thaw resistance. The test specimens were in saturated-surface-dry (SSD) conditions, but not immersed in water. This simulated the natural conditions of freeze/thaw cycles in most application of $\mathrm{CMU}$ and cement concrete in construction.

3. CMU test specimens made with manufactured lightweight aggregates from either limestone wet FGD materials or spray dryer ash had medium freeze/thaw resistance after 20 cycles of treatments. Test specimens made with aggregates from lime wet FGD materials were degraded after 20 cycles of treatment. In comparison, asphalt concrete made with manufactured road aggregate from lime wet FGD material had high freeze/thaw resistance after 200 cycles of treatment. Test specimens were immersed in water during freeze/thaw treatments. Test results indicate that immersion in water had a profound effect on the freeze/thaw resistance of CMU made with manufactured lightweight aggregate. Mix designs for aggregate and aggregate products production need to be modified, if simultaneous freeze/thaw cycles at extremely low temperature and water immersion cannot be avoided in the application.

Table B. Durability Characteristics of Manufactured Aggregate Products

\begin{tabular}{|l|c|c|c|}
\hline Test Specimens & $\begin{array}{c}\text { Wet/Dry } \\
\text { Treatment }\end{array}$ & $\begin{array}{c}\text { Freeze/Thaw } \\
\text { Treatment } \\
\text { (SSD) }\end{array}$ & $\begin{array}{c}\text { Freeze/Thaw } \\
\text { Treatment } \\
\text { (Immersion in } \\
\text { water) }\end{array}$ \\
\hline $\begin{array}{l}\text { Concrete Masonry Units } \\
\text { Limestone wet FGD Aggregate } \\
\text { (Fixated with Class F fly ash) } \\
\begin{array}{l}\text { Lime wet FGD aggregate } \\
\text { (Fixated with low and high LOI fly ash) } \\
\text { Spray dryer ash aggregate } \\
\text { (With Class F fly ash) }\end{array}\end{array} \quad$ High & High & Medium \\
\hline $\begin{array}{l}\text { Cement Concrete } \\
\text { Lime wet FGD aggregate } \\
\text { (Fixated with low and high LOI fly ash) }\end{array}$ & High & High & Medium \\
\hline $\begin{array}{l}\text { Asphalt Concrete } \\
\text { Lime wet FGD aggregate } \\
\text { (Fixated with low LOI fly ash) }\end{array}$ & (a) & High & (a) \\
\hline
\end{tabular}

(a) Not determined 


\section{SUMMARY OF RELATED WORKS}

Large quantities of lightweight aggregates and road aggregates were produced at the pilot-plant or bench-scale and these materials were used in field demonstrations with commercial equipment. Lightweight aggregates were used for concrete masonry units $(\mathrm{CMU})$ production at commercial concrete block plants and in qualification tests for use as lightweight structural concrete. Road aggregates were used in asphalt concrete pavement construction. Test specimens from CMU, cement concrete and asphalt concrete were used in this study for the determination of durability characteristics of manufactured aggregate products. Certain related works conducted by the author of this report, which are relevant to this study, are summarized below in accordance with published reports. These works were conducted with partial funding from the Department of Energy (DOE) and the Ohio Coal Development Office (OCDO). The three cited reports, in addition to this report, provide an extensive body of experience in manufacturing aggregates from coal combustion by-products (CCBs).

1. McCoy, D.C., Wu, M. M, "Demonstration of the Production of Manufactured Aggregates from AEP Gavin and Conesville Station FGD Sludge", OCDO Final Report, Grant Agreement No. CDO/D-98-17, May 31, 2003.

About 25 tons of lightweight aggregate was produced from lime wet FGD material fixated with a blend of low and high LOI fly ash in pilot plant operation. FGD sludge and low LOI fly ash were collected from the AEP Conesville Station. High LOI fly ash was collected from the FirstEnergy Sammis Station. The manufactured lightweight aggregate was used in block plants for CMU production and in qualification tests for use in lightweight structural concrete. The lightweight concrete blocks and structural concrete specimens made with wet FGD manufactured aggregate met all ASTM C-90 specifications for load-bearing concrete masonry units and all ASTM C-330 specifications for lightweight structural concrete, except for drying shrinkage. Drying shrinkage could be caused by manufactured aggregate alone or by interaction of manufactured aggregate and other concrete block components (e. g., cement) during wet/dry treatment. The effects of these factors on durability characteristics of aggregate and aggregate products are included in this cited study.

2. Wu, M. M., McCoy, D. C., "Aggregate Production from Lime Wet FGD Sludge", OCDO Final Report, Grant Agreement No. CDO/D-95-2, October, 2003

About 2.5 tons of road aggregate was produced from lime wet FGD material fixated with low LOI fly ash (AEP Gavin Station in Ohio) and with cement addition in a semicontinuous bench-scale unit. The road aggregate met AASHTO M283 specifications for Class A aggregate in highway construction. An asphalt concrete pavement $\left(72^{\prime} \times 11^{\prime} \mathrm{x}\right.$ $1.5^{\prime}$ ) was constructed using crushed manufactured aggregate (No. 8 size) as half of the coarse aggregate in the surface wearing course in Warren, Ohio in October 1998. Core samples were collected and used in the aggregate products durability evaluation. 
3. Wu, M. M., McCoy, D. C., Scandrol, R. O., Fenger, M. L., Withum, J. A., Statnick, R. M., "Production of Construction Aggregates from Flue Gas Desulfurization Sludge", DOE Final Report, Cooperative Agreement No. DE-FC26-98FT40027, May 2000.

About 72 tons of road aggregate was produced from lime wet FGD material fixated with a low LOI fly ash and with cement addition in a pilot plant operation. FGD sludge was collected from the Reliant Energy Elrama Station in Pennsylvania. The low LOI fly ash was collected from the Allegheny Power Hatfield's Ferry Station in Pennsylvania. The road aggregates produced met AASHTO M283 specifications for use as Class A aggregate in highway construction. Two asphalt concrete pavements (350' $\times 12^{\prime} \times 1.5^{\prime}$ and 400' $x$ 12' $\times 1.5^{\prime}$ ) were constructed using crushed manufactured aggregates (No. 8 size) as half of the coarse aggregates in the surface wearing courses in South Park, Pennsylvania, and in Nokomis, Florida. Core samples were collected and used in the aggregate products durability evaluation. 


\section{EXPERIMENTAL}

\section{Preparation of Manufactured Aggregates}

Manufactured aggregates were produced in a three-step process consisting of mixing, disk pelletizing and curing. Various feed components for a specific mix design were mixed in a Littleford Brothers FM-50 mixer (Model KM-300-D) to produce a consistent mixed material for pelletization. The disk pelletization was conducted by adding the mixed material to a Ferro-Tech Inc. disk pelletizer (36" diameter Model 036 or 16" diameter Model 016) at a feed rate of about $13.4 \mathrm{lb} / \mathrm{min}$ for agglomeration. The pelletization time is about 20 to 25 minutes. The pelletized products were then mixed with embedding material and placed in the 55-gallon heated vessel for curing. The blended products were cured at about $160{ }^{\circ} \mathrm{F}$ to $170{ }^{\circ} \mathrm{F}$ and 90 to $100 \%$ relative humidity for $24 \mathrm{hr}$. About $100 \mathrm{lb}$ to $200 \mathrm{lb}$ of the aggregate was produced for the determination of aggregate properties including crush strength, LA abrasion, unit weight, soundness, or particle size distribution. The crush strength was determined with uncrushed aggregates with a Soiltest compressive strength machine. The aggregate crush strength reported is the average of ten measurements on ca. 1/2"x3/8" pellets (uncrushed). The LA abrasion index, unit weight, soundness index and particle size distribution were determined with crushed aggregates in accordance with the standard ASTM procedures. In addition to disk pelletization, several agglomeration runs were conducted with extrusion using a Van Ho extruder (Model NL-320) to produce green extruded products for curing. The extruded products were cured in the same conditions as those produced from disk pelletization runs.

\section{Other Methods}

Additional experimental details appear in the Results and Discussion section, where appropriate. 


\section{RESULTS AND DISCUSSION}

\section{Sample Collections and Characterization}

The objectives of this task are to collect and characterize coal combustion by-products (CCBs) samples with different chemical compositions. These materials will be used to prepare manufactured aggregates in the next task. The CCBs samples include limestone wet flue gas desulfurization (FGD) sludge fixated with Class $F$ and Class $C$ fly ash, lime wet FGD sludge fixated with high loss on ignition (LOI) and low LOI fly ash, fluidized bed combustion (FBC) ash generated from combustion of low and high-sulfur coals, Class $\mathrm{F}$ and Class $\mathrm{C}$ pulverized coal fly ash, and spray dryer ash containing Class $\mathrm{F}$ and Class $\mathrm{C}$ fly ash.

Limestone wet FGD filter cake; Class F and C fly ash for use in fixation were collected from Lakeland Mclntosh Station in Florida (Sample No. FGD-LS-FS) and Reliant Energy Limestone Station in Texas (Sample No. FGD-LS-TS). Lime wet FGD filter cake and high LOI fly ash for use in fixation were collected from Reliant Energy Elrama Station in Pennsylvania (Sample No. FGD-LM-PS). Lime wet FGD filter cake and low LOI fly ash for use in fixation were collected from AEP Galvin and Conesville Stations in Ohio (Samples Nos. FGD-LM-OS-1 and FGD-LM-OS-2), respectively. FBC ash samples generated from combustion of low-sulfur coals were collected from New Mexico Power TNP One Station in Texas (Sample No. FBC-TS) and AES Guayama Station in Puerto Rico (Sample No. FBC-PR). FBC ash generated from combustion of a blend of highsulfur coal and petroleum coke (30/70) was collected from JEA Northside Station in Florida (Sample No. FBC-FS). In addition, FBC ash samples generated from combustion of low-sulfur lignite and waste coal (or gob) was collected from Tractebel Power Red Hill Station in Mississippi (Sample No. FBS-MS) and PG\&E Northampton Station in Pennsylvania (Sample No. FBC-PS), respectively. Class C and Class F fly ash were collected from GPCO Scherer Station in Georgia (Sample No. FY-GS) and JEA Seminole Station in Florida (Sample No. FY-FS). Spray dryer ash containing Class $\mathrm{F}$ and $\mathrm{C}$ fly ash were collected from Birchwood Power Facilities in Virginia (Samples No. SDA-VS) and Sunflower Power Holcomb Station in Kansas (Sample No. SDA-KS).

The characterization results are shown below in Tables 1-A, 1-B, 1-C-1, 1-C-2, 1-D, and $1-E$ in accordance with types of CCBs (i.e., wet limestone and lime FGD materials, FBC ash, fly ash and spray dryer ash). The tables include moisture content, ultimate analyses and major elements. In addition, the tables include available data of LOI (loss on ignition), sulfur forms, solids concentration, specific gravity, lime index, and particle size distribution. 
Table 1-A. Analyses of Limestone Wet FGD Materials

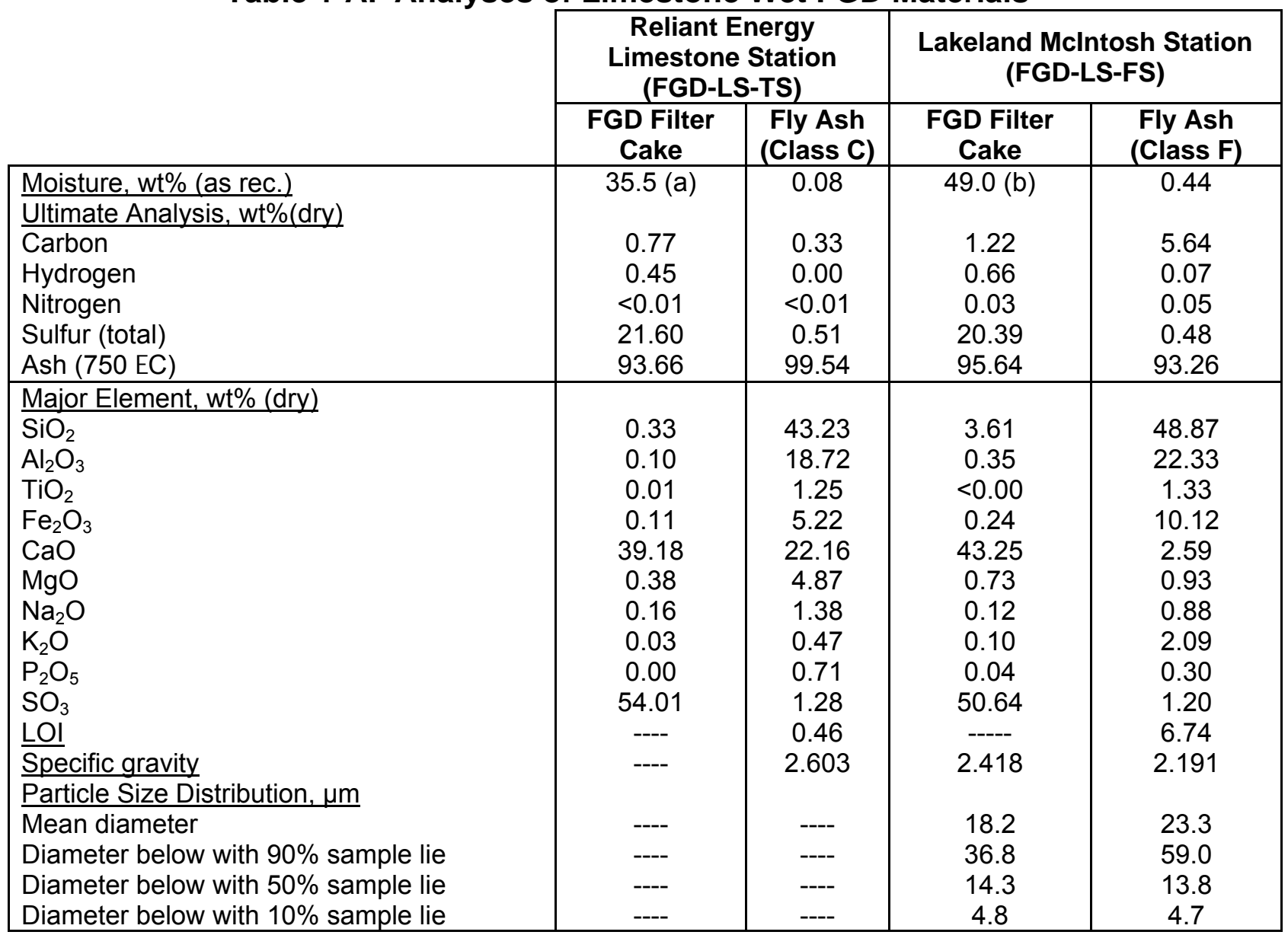

(a) Solids concentration of $64.5 \%$

(b) Solids concentration of $51.0 \%$ 
Table 1-B. Analyses of Lime Wet FGD Materials

\begin{tabular}{|c|c|c|c|c|c|c|}
\hline & \multicolumn{2}{|c|}{$\begin{array}{l}\text { Reliant Energy } \\
\text { Elrama Station } \\
\text { (FGD-LM-PS) }\end{array}$} & \multicolumn{2}{|c|}{$\begin{array}{l}\text { AEP Gavin Station } \\
\text { (FGD-LM-OS-1) }\end{array}$} & \multicolumn{2}{|c|}{$\begin{array}{l}\text { AEP Conesville Station } \\
\text { (FGD-LM-OS-2) }\end{array}$} \\
\hline & $\begin{array}{l}\text { FGD } \\
\text { Filter } \\
\text { Cake }\end{array}$ & Fly Ash & $\begin{array}{l}\text { FGD Filter } \\
\text { Cake }\end{array}$ & Fly Ash & $\begin{array}{l}\text { FGD Filter } \\
\text { Cake }\end{array}$ & Fly Ash \\
\hline $\begin{array}{l}\text { Moisture, wt\% (as rec.) } \\
\text { Ultimate Analysis, wt } \%(\text { dry) }\end{array}$ & $46.0(a)$ & 0.27 & $55.1(\mathrm{~b})$ & 0.05 & $58.6(c)$ & 0.17 \\
\hline Carbon & 5.01 & 22.52 & 0.66 & 0.66 & 0.35 & 0.99 \\
\hline Hydrogen & 1.15 & 0.02 & 0.09 & 0.09 & 0.89 & 0.02 \\
\hline Nitrogen & $<0.01$ & 0.27 & $<0.01$ & $<0.01$ & $<0.01$ & 0.01 \\
\hline Sulfur (total) & 12.15 & 0.42 & 22.48 & 0.26 & 19.92 & 0.39 \\
\hline Sulfate Sulfur & 1.92 & --- & 1.89 & ---- & 7.88 & --- \\
\hline Sulfite Sulfur & 10.22 & ---- & 20.59 & ---- & 12.04 & ----- \\
\hline Ash $\left(750^{\circ} \mathrm{C}\right)$ & 91.75 & 77.01 & 96.16 & 99.02 & 98.18 & 98.49 \\
\hline Major Element, wt\% (dry) & & & & & & \\
\hline $\mathrm{SiO}_{2}$ & 17.55 & 42.53 & 1.45 & 47.63 & 1.80 & 44.93 \\
\hline $\mathrm{Al}_{2} \mathrm{O}_{3}$ & 8.06 & 18.02 & 0.38 & 23.91 & 0.42 & 23.29 \\
\hline $\mathrm{TiO}_{2}$ & 0.38 & 0.76 & 0.02 & 1.17 & 0.01 & 1.17 \\
\hline $\mathrm{Fe}_{2} \mathrm{O}_{3}$ & 3.56 & 11.75 & 0.16 & 21.16 & 0.18 & 22.57 \\
\hline $\mathrm{CaO}$ & 28.81 & 2.06 & 42.11 & 2.45 & 42.59 & 2.56 \\
\hline $\mathrm{MgO}$ & 1.33 & 0.72 & 1.43 & 0.92 & 1.37 & 0.80 \\
\hline $\mathrm{Na}_{2} \mathrm{O}$ & 0.28 & 0.55 & 0.07 & 0.31 & 0.10 & 0.41 \\
\hline $\mathrm{K}_{2} \mathrm{O}$ & 0.73 & 1.62 & 0.01 & 2.07 & 0.09 & 1.86 \\
\hline $\mathrm{P}_{2} \mathrm{O}_{5}$ & 0.13 & 0.24 & $<0.01$ & 0.40 & 0.00 & 0.35 \\
\hline $\mathrm{SO}_{3}$ & 34.09 & 0.61 & 56.21 & 0.64 & 49.81 & 0.98 \\
\hline LOI & ---- & 22.93 & ---- & 0.98 & ---- & 1.51 \\
\hline Specific Gravity & 2.201 & 2.180 & ----- & 2.544 & 2.289 & 2.456 \\
\hline Particle Size Distribution, $\mu \mathrm{m}$ & & & & & & \\
\hline Mean diameter & 11.7 & ---- & 32.6 & ---- & ---- & ---- \\
\hline Diameter below with $90 \%$ sample lie & 19.9 & ---- & 58.5 & ---- & ---- & ---- \\
\hline Diameter below with $50 \%$ sample lie & 10.5 & --- & 28.6 & ---- & ---- & ---- \\
\hline Diameter below with $10 \%$ sample lie & 4.9 & ---- & 10.7 & ---- & ---- & ---- \\
\hline
\end{tabular}

(a) Solids concentration of $54.0 \%$

(b) Solids concentration of $44.9 \%$

(c) Solids concentration of $41.4 \%$ 
Table 1-C-1. Analyses of FBC Ash (From Low and High Sulfur Coals)

\begin{tabular}{|c|c|c|c|c|}
\hline & $\begin{array}{c}\text { New Mexico } \\
\text { Power TNP One } \\
\text { Station (FBC-TS) }\end{array}$ & $\begin{array}{c}\text { AES } \\
\text { Guayama } \\
\text { Station (FBC- } \\
\text { PR) }\end{array}$ & $\begin{array}{c}\text { JEA } \\
\text { Northside } \\
\text { Station (FBC- } \\
\text { FS) } \\
\end{array}$ & $\begin{array}{c}\text { Tractebel Power } \\
\text { Red Hills Station } \\
\text { (FBC-MS) }\end{array}$ \\
\hline $\begin{array}{l}\text { Moisture, wt\% (as rec.) } \\
\text { Ultimate Analysis, wt\%(dry) }\end{array}$ & 0.12 & 0.13 & 0.12 & 0.14 \\
\hline Carbon & 0.60 & 4.16 & 8.26 & 0.26 \\
\hline Hydrogen & 0.03 & 0.18 & 0.25 & $<0.01$ \\
\hline Nitrogen & $<0.01$ & 0.08 & 0.12 & $<0.01$ \\
\hline Sulfur (total) & 3.01 & 4.35 & 8.66 & 2.52 \\
\hline Sulfate sulfur & 3.01 & 4.35 & 8.66 & 2.52 \\
\hline Ash $(750 \quad$ C $)$ & 98.08 & 95.16 & 84.95 & 99.54 \\
\hline Major Element, wt\% (dry) & & & & \\
\hline $\mathrm{SiO}_{2}$ & 48.50 & 38.90 & 6.26 & 51.05 \\
\hline $\mathrm{Al}_{2} \mathrm{O}_{3}$ & 16.79 & 13.31 & 3.31 & 16.02 \\
\hline $\mathrm{TiO}_{2}$ & 1.00 & 0.50 & 0.15 & 0.89 \\
\hline $\mathrm{Fe}_{2} \mathrm{O}_{3}$ & 4.47 & 5.91 & 2.60 & 3.92 \\
\hline $\mathrm{CaO}$ & 23.00 & 17.61 & 48.77 & 18.44 \\
\hline $\mathrm{MgO}$ & 2.62 & 0.64 & 0.62 & 2.48 \\
\hline $\mathrm{Na}_{2} \mathrm{O}$ & 0.51 & 2.97 & 0.36 & 0.42 \\
\hline $\mathrm{K}_{2} \mathrm{O}$ & 0.83 & 1.28 & 0.13 & 1.04 \\
\hline $\mathrm{P}_{2} \mathrm{O}_{5}$ & 0.14 & 0.09 & 0.06 & 0.08 \\
\hline $\begin{array}{l}\mathrm{SO}_{3} \\
\text { Components wt \% drv }\end{array}$ & 7.53 & 10.87 & 21.64 & 6.03 \\
\hline $\mathrm{CaO}(\mathrm{a})$ & 2.5 & 3.3 & 16.5 & (c) \\
\hline $\mathrm{CaSO}_{4}(\mathrm{~b})$ & 12.8 & 18.5 & 36.8 & 10.7 \\
\hline
\end{tabular}

(a) Based on thermogravimetric analysis (TGA) or lime index measurements

(b) Based on the total sulfur content in ash

(c) None detectable 


\section{Table 1-C-2. Analyses of FBC Ash (From Waste Coal)}

\begin{tabular}{|c|c|}
\hline & $\begin{array}{l}\text { PG\&E Northampton } \\
\text { Station (FBC-PS) }\end{array}$ \\
\hline Moisture, wt\% (as rec.) & 0.08 \\
\hline Ultimate Analysis, wt\% (dry) & \\
\hline Carbon & 6.40 \\
\hline Hydrogen & 0.06 \\
\hline Nitrogen & 0.05 \\
\hline Sulfur & 2.42 \\
\hline Sulfate sulfur & 2.42 \\
\hline Ash $\left(750^{\circ} \mathrm{F}\right)$ & 89.94 \\
\hline \multicolumn{2}{|l|}{ Major Element (a), wt\% (dry) } \\
\hline $\mathrm{SiO}_{2}$ & 40.23 \\
\hline $\mathrm{Al}_{2} \mathrm{O}_{3}$ & 17.94 \\
\hline $\mathrm{TiO}_{2}$ & 0.80 \\
\hline $\mathrm{Fe}_{2} \mathrm{O}_{3}$ & 5.65 \\
\hline $\mathrm{CaO}$ & 14.81 \\
\hline $\mathrm{MgO}$ & 1.76 \\
\hline $\mathrm{Na}_{2} \mathrm{O}$ & 0.52 \\
\hline $\mathrm{K}_{2} \mathrm{O}$ & 2.04 \\
\hline $\mathrm{P}_{2} \mathrm{O}_{5}$ & 0.16 \\
\hline $\mathrm{SO}_{3}$ & 6.06 \\
\hline \multicolumn{2}{|l|}{ Components, wt\% (dry) } \\
\hline $\mathrm{CaO}(\mathrm{a})$ & 2.5 \\
\hline $\mathrm{CaSO}_{4}(\mathrm{~b})$ & 10.3 \\
\hline
\end{tabular}

(a) Based on thermogravimetric analysis (TGA)

(b) Based on total sulfur content in ash 
Table 1-D. Analyses of Pulverized Coal Fly Ash

\begin{tabular}{|c|c|c|c|}
\hline & $\begin{array}{l}\text { Class C Fly Ash } \\
\text { from GPCO } \\
\text { Scherer Station } \\
\text { (FY-GS) }\end{array}$ & $\begin{array}{l}\text { Class F Fly Ash } \\
\text { from JEA Seminole } \\
\text { Station (FY-FS) }\end{array}$ & $\begin{array}{c}\text { Class F Fly Ash from } \\
\text { First Energy Sammis } \\
\text { Station } \\
\text { (FY-OS) }\end{array}$ \\
\hline $\begin{array}{l}\text { Moisture, wt } \% \text { (as rec.) } \\
\text { Ultimate Analysis, wt } \%(\text { dry) }\end{array}$ & 0.01 & 0.22 & 0.25 \\
\hline Carbon & 0.25 & 5.41 & 14.79 \\
\hline Hydrogen & $<0.01$ & 0.08 & 0.05 \\
\hline Nitrogen & $<0.01$ & 0.04 & 0.15 \\
\hline Sulfur (total) & 0.45 & 0.45 & 0.13 \\
\hline Ash $(750$ C $)$ & 99.70 & 93.82 & 84.37 \\
\hline \multicolumn{4}{|l|}{ Major Element, wt\% (dry) } \\
\hline $\mathrm{SiO}_{2}$ & 37.56 & 44.06 & 47.34 \\
\hline $\mathrm{Al}_{2} \mathrm{O}_{3}$ & 19.60 & 18.83 & 24.50 \\
\hline $\mathrm{TiO}_{2}$ & 1.45 & 0.98 & 1.26 \\
\hline $\mathrm{Fe}_{2} \mathrm{O}_{3}$ & 7.13 & 20.67 & 4.42 \\
\hline $\mathrm{CaO}$ & 24.30 & 3.77 & 1.08 \\
\hline $\mathrm{MgO}$ & 5.39 & 0.92 & 0.75 \\
\hline $\mathrm{Na}_{2} \mathrm{O}$ & 1.85 & 0.72 & 0.24 \\
\hline $\mathrm{K}_{2} \mathrm{O}$ & 0.64 & 1.88 & 2.02 \\
\hline $\mathrm{P}_{2} \mathrm{O}_{5}$ & 1.49 & 0.10 & 0.18 \\
\hline $\mathrm{SO}_{3}$ & 1.13 & 1.13 & 0.33 \\
\hline $\mathrm{LOI}$ & 0.30 & 6.18 & 15.63 \\
\hline Specific Gravity & 2.608 & 2.388 & 1.971 \\
\hline \multicolumn{4}{|l|}{ Particle Size Distribution, $\mu \mathrm{m}$} \\
\hline Mean diameter & 25.8 & --- & ---- \\
\hline Diameter below with $90 \%$ sample lie & 78.3 & ---- & ---- \\
\hline Diameter below with $50 \%$ sample lie & 10.1 & ---- & ---- \\
\hline Diameter below with $10 \%$ sample lie & 2.7 & ---- & --- \\
\hline
\end{tabular}


Table 1-E. Analyses of Spray Dryer Ash

\begin{tabular}{|c|c|c|}
\hline & $\begin{array}{c}\text { Birchwood Power Partners } \\
\text { Station (SDA-VS) }\end{array}$ & $\begin{array}{c}\text { Sunflower Power Holcomb } \\
\text { Station (SDA-KS) }\end{array}$ \\
\hline$\frac{\text { Moisture, wt\% (as rec.) }}{\text { Ultimate Analysis, wt } \% \text { (dry) }}$ & 1.22 & 1.71 \\
\hline Carbon & 5.57 & 0.17 \\
\hline Hydrogen & 0.99 & 0.01 \\
\hline Nitrogen & 0.05 & 0.08 \\
\hline Sulfur (total) & 3.17 & 4.79 \\
\hline Sulfite sulfur & 3.17 & 4.79 \\
\hline Ash $(750 \quad$ C) & 84.16 & 97.35 \\
\hline Major Element, wt\% (dry) & & \\
\hline $\mathrm{SiO}_{2}$ & 24.05 & 30.22 \\
\hline $\mathrm{Al}_{2} \mathrm{O}_{3}$ & 11.52 & 15.89 \\
\hline $\mathrm{TiO}_{2}$ & 0.57 & 1.19 \\
\hline $\mathrm{Fe}_{2} \mathrm{O}_{3}$ & 2.21 & 3.79 \\
\hline $\mathrm{CaO}$ & 34.13 & 25.66 \\
\hline $\mathrm{MgO}$ & 0.89 & 3.90 \\
\hline $\mathrm{Na}_{2} \mathrm{O}$ & 0.13 & 1.82 \\
\hline $\mathrm{K}_{2} \mathrm{O}$ & 1.10 & 0.43 \\
\hline $\mathrm{P}_{2} \mathrm{O}_{5}$ & 0.03 & 1.01 \\
\hline $\mathrm{SO}_{3}$ & 7.92 & 11.98 \\
\hline Specific Gravity & 2.088 & 2.560 \\
\hline Particle Size Distribution, $\mu \mathrm{m}$ & & \\
\hline Mean diameter & 13.5 & --- \\
\hline Diameter below with $90 \%$ sample lie & 32.5 & --- \\
\hline Diameter below with $50 \%$ sample lie & 8.9 & ---- \\
\hline Diameter below with $10 \%$ sample lie & 2.3 & \\
\hline $\mathrm{Ca}(\mathrm{OH})_{2}(\mathrm{a})$ & 25.0 & 8.5 \\
\hline $\mathrm{CaSO}_{3}(\mathrm{~b})$ & 11.89 & 17.96 \\
\hline
\end{tabular}

Based on thermogravimetric analysis (TGA) or lime index measurement Based on total sulfur content in ash

\section{Preparation and Characterization of Manufactured Aggregates}

The objectives of this task are to prepare manufactured aggregate and to determine the aggregate properties as the baseline for the durability study. All manufactured aggregates planned for the project were prepared and characterized. See the Experimental section for preparation details.

Test conditions and properties of pelletized and extruded products made from various CCBs as feed materials are listed below in Tables 2A-1, 2A-2, 2B-1, 2B-2, 3B-3, 2C-1, 2C-2, 2C-3, 2C-4, 2D-1, 2E-1, 2E-2 in accordance with CCBs collected from individual power stations. CCBs include limestone wet FGD, lime wet FGD, FBC ash, fly ash and spray dryer ash as discussed below.

\section{Limestone Wet FGD}

Fixated with Class C Fly Ash As shown in Table 2-A-1, four pelletization tests (Test Nos. FGD-LS-TS-1 to FGD-LS-4) were conducted to evaluate the effects of mix 
formulation and Class $\mathrm{C}$ fly ash addition on properties of aggregates made with fixated limestone wet FGD materials from Reliant Energy Limestone Station in Texas. Mixer feed, operating conditions and properties of aggregates are listed in the table for comparison. In Test Nos. FGD-LS-TS-1 and FGD-LS-TS-2, aggregate products were made from FGD filter cake, lignite fly ash, hydrated lime and water with slightly different mix ratios. The aggregates produced had crush strengths of $79 \pm 11 \mathrm{lb}$ and $90 \pm 10 \mathrm{lb}$, unit weights of $69.9 \mathrm{lb} / \mathrm{ft}^{3}$ and $72.9 \mathrm{l} / \mathrm{ft}^{3}$ (as-is) and $63.4 \mathrm{lb} / \mathrm{ft}^{3}$ and $68.1 \mathrm{lb} / \mathrm{ft}^{3}$ (dry), respectively. In Test No. FGD-LS-TS-3, a subbituminous coal fly ash (Class C) was used to replace $50 \%$ of the lignite fly ash in the mix feed. The aggregates produced had a crush strength of $226 \pm 78 \mathrm{lb}$ and unit weights of $74.0 \mathrm{lb} / \mathrm{ft}^{3}$ (as-is) and $68.3 \mathrm{lb} / \mathrm{ft}^{3}$ (dry). In Test No. FGD-LS-TS-4, 100\% Class C fly ash was used as the fly ash component in the mix feed. The aggregates produced had a crush strength of $246 \pm 45 \mathrm{lb}$ and unit weights of $75.2 \mathrm{lb} / \mathrm{ft}^{3}$ (as-is) and $69.6 \mathrm{lb} / \mathrm{ft}^{3}$ (dry). In all tests, unit weights were determined with crushed aggregates meeting ASTM No. 8 and 9 size gradations (combined fine and coarse aggregates).

Test results show that the crush strength of aggregate increased substantially with addition of Class $C$ fly ash in mix feed. Aggregates with high crush strength (over 200 Ib) can be made with Class $C$ fly ash in fixated FGD material. However, dry unit weights of aggregates produced did not meet the ASTM C331 specification (i.e., $65 \mathrm{lb} / \mathrm{ft}^{3}$, max. for combined aggregate) for use as lightweight aggregate in concrete masonry units $(\mathrm{CMU})$. The strong aggregate may be used in road construction.

The aggregate made with $100 \%$ Class C fly ash in Test No. FGD-LS-TS-4 was selected for use in the durability study in the next task.

Fixated with Class F Fly Ash. As shown in Table 2-A-2, three pelletization tests (Test Nos. FGD LS-FS-1 to FGD-LS-FS-3) and one extrusion test (Test No. FGD-LS-FS-4) were conducted to evaluated the effects of mix formulation and Class $\mathrm{F}$ fly ash addition on properties of aggregates made with fixated limestone wet FGD materials from Lakeland McIntosh Station in Florida. Mixer feed, operating conditions and properties of aggregates are listed in the table for comparison. In Test Nos. FGD-LS-FS-1 and FGD-LS-FS-2, aggregate products were made from FGD filter cake, Class F fly ash, hydrated lime and water with different mix ratios. The aggregates produced had crush strengths of $164 \pm 40 \mathrm{lb}$ and $143 \pm 36 \mathrm{lb}$, unit weights of $61.2 \mathrm{lb} / \mathrm{ft}^{3}$ and $65.0 \mathrm{lb} / \mathrm{ft}^{3}$ (as-is) and $54.0 \mathrm{lb} / \mathrm{ft}^{3}$ and $56.8 \mathrm{lb} / \mathrm{ft}^{3}$ (dry), respectively. The aggregate produced from Test No. FGD-LS-FS-2 had a soundness index of $21.6 \%$. In Test No. FGD-LS-FS-3, bottom ash was added to the mix feed. The aggregate produced had a crush strength of $121 \pm 24 \mathrm{lb}$ and unit weight of $64.3 \mathrm{lb} / \mathrm{ft}^{3}$ (as-is) and $55.7 \mathrm{lb} / \mathrm{ft}^{3}$ (dry). In Test No.FGD-LS-FS-4, the aggregate produced from extrusion had a crush strength of $464 \pm 43 \mathrm{lb}$ and unit weights of $64.6 \mathrm{lb} / \mathrm{ft}^{3}$ (as-is) and $55.6 \mathrm{lb} / \mathrm{ft}^{3}$ (dry). The crush strength was higher than those with aggregates made from disk pelletization, because products with different dimensions were used for the measurements. For the extrusion product, the aggregate crush strength was determined with cylindrical extruded products with lengths of 1.5" to 1.7" and diameter of 1". For the disk pelletization product, the aggregate crush strength was determined with spherical palletized products with $1 / 2$ " $\times 3 / 8$ " diameters. In all tests, unit 
weights were determined with crushed aggregates meeting ASTM No. 8 and 9 size gradation (combined fine and coarse aggregates).

Test results show that aggregates produced had adequate crush strengths for use in CMU production. Based on the previous block production demonstration work at CONSOL Energy and Universal Aggregates, aggregate with crush strength over $100 \mathrm{lb}$ (prepared from disk pelletization) and over $400 \mathrm{lb}$ (prepared from extrusion) can produce CMU meeting ASTM C90 compressive strength specification. Dry unit weights of aggregates met the ASTM C331 specification $\left(65 \mathrm{lb} / \mathrm{ft}^{3}\right.$, max. for combined aggregate) for use as lightweight weight in CMU. In comparison, the aggregate produced in Test No. FGD-LS-FS-2 had a soundness index of $21.6 \%$, which does not meet AASHTO Class A aggregate specifications (12\%, max.) for used in road construction.

In a separate project, internally funded by Universal Aggregates, lightweight aggregate was produced at the pilot plant scale and the product was used in block production demonstration. The mix formulation and operation conditions used at the pilot plant were similar to those used in Test No.FGD-LS-FS-4. The aggregate produced from Test No. FGD-LS-FS-2 was used in the aggregate durability study. The aggregate produced from the pilot plant was used for $\mathrm{CMU}$ production and for aggregate products durability study.

\section{Lime Wet FGD}

Fixated with High LOI Fly Ash. As shown in Table 2-B-1, three pelletization tests (Test Nos. FGD-LM-PS-1 to FGD-LM-PS-3) were conducted to evaluate the effects of mix formation and high LOI fly ash $(22.93 \%$ in Table $1-B)$ on properties of aggregates made with fixated lime wet FGD from Reliant Energy Elrama Station in Pennsylvania. Mixer feed, operating conditions and properties of aggregates are listed in the table for comparison. In Test Nos. FGD-LM-PS-1 and FGD-LM-PS-2, products were made from FGD filter cake, high LOI fly ash, quick lime and water with different mix ratios. The aggregates produced had a crush strengths of $37 \pm 12 \mathrm{lb}$ and $58 \pm 19 \mathrm{lb}$, LA abrasion index of $59.9 \%$ and $42,6 \%$, unit weights of $55.3 \mathrm{lb} / \mathrm{ft}^{3}$ and $58.3 \mathrm{lb} / \mathrm{ft}^{3}$ (as-is) and 51.4 $\mathrm{lb} / \mathrm{ft}^{3}$ and $53.1 \mathrm{lb} / \mathrm{ft}^{3}$ (dry), respectively. In Test No. FGD-LM-FS-3, hydrated lime was used to replace quick lime in mix feed. The aggregate produced had a crush strength of $97 \pm 31 \mathrm{lb}$, LA abrasion index of $34,6 \%$, unit weights of $63.9 \mathrm{lb} / \mathrm{ft}^{3}$ (as-is) and $57.5 \mathrm{lb} / \mathrm{ft}^{3}$ (dry) and soundness index of $81.0 \%$. In all tests, unit weights were determined with crushed aggregates meeting ASTM No. 8 and 9 size gradation (fine and combined aggregates).

Test results show that all aggregates produced from these tests had a crush strength less than $100 \mathrm{lb}$. The aggregate crush strengths did not meet the strength criteria (100 $\mathrm{lb}$, min.) for use in $\mathrm{CMU}$ production, even though aggregate unit weights meet the ASTM C331 specification for use as lightweight aggregate in CMU. The aggregates produced in Test Nos. FGD-LM-PS-1 and FGD-LM-PS-2 had LA abrasion indices of $59.9 \%$ and $42.6 \%$. The aggregate produced in Test No. FGD-LM-PS-3 had soundness 
index of $81.1 \%$. These index values did not meet AASHTO Class A specifications of LA abrasion index (40\%, max.) and soundness index (12\%, max.) for use in road construction.

The aggregate produced in Test No. FGD-LM-PS-3 was selected for use as reference in the aggregate durability study in Task 4.

Fixated with Low LOI Fly Ash. As shown in Table 2-B-2, four pelletization tests (Test Nos. FGD-LM-OS-1-1 to FGD-LM-OS-1-4) were conducted to evaluate the effects of mix formulation and low LOI fly $(0.98 \%$ in Table 1-B) ash on properties of aggregates made with fixated lime wet FGD materials from AEP Gavin Station in Ohio. Mixer feed, operating conditions and properties of aggregates are listed in the table for comparison. In Test No. FGD-LS-OS-1-1, aggregate was made from FGD filter cake, low LOI fly ash, quick lime and water. The aggregate produced had a crush strength of $106 \pm 26 \mathrm{lb}, \mathrm{LA}$ abrasion index of $51 \%$, unit weights of $73.7 \mathrm{lb} / \mathrm{ft}^{3}$ (as-is) and $66.3 \mathrm{lb} / \mathrm{ft}^{3}$ (dry) and soundness index of $49 \%$. In Test No. FGD-LS-OS-1-2, hydrated lime was used to replace quick lime in mix feed. The crush strength increased to $106 \pm 26 \mathrm{lb}$. The LA abrasion and soundness indices decreased to $45 \%$ and $46 \%$, respectively. The aggregate had unit weights of $72.3 \mathrm{lb} / \mathrm{ft}^{3}$ (as-is) and $65.1 \mathrm{lb} / \mathrm{ft}^{3}$ (dry). In Test No. FGDLS-OS-1-3, hydrated lime content in mix feed increased to $12.8 \%$. The aggregate produced had a crush strength of $123 \pm 49 \mathrm{lb}$, LA abrasion index of $42 \%$, unit weights of $74.3 \mathrm{lb} / \mathrm{ft}^{3}$ (as-is) and $66.8 \mathrm{lb} / \mathrm{ft}^{3}$ (dry) and soundness index of $79 \%$. In Test No. FGDLS-OS-1-4, the mix feed is the same as those in Test No. FGD-LS-OS-1-3 except that $13.2 \%$ of cement was added to replace fly ash. The crush strength increased substantially to $232 \pm 88 \mathrm{lb}$ and the LA abrasion and soundness indices decreased substantially to $30 \%$ and $5 \%$ respectively,. The aggregate had unit weights of $75.8 \mathrm{lb} / \mathrm{ft}^{3}$ (as-is) and $68.1 \mathrm{lb} / \mathrm{ft}^{3}$ (dry). In all tests, the unit weights were determined with crushed coarse aggregates with $50 \%$ or more above $1 / 2$.

Test results show that aggregate with high crush strength (over $200 \mathrm{lb}$ ) can be made with cement addition, but not with increased hydrated lime content in the mix feed. In all tests, dry unit weights of aggregates produced did not meet the ASTM C331 specification (i.e., $55 \mathrm{lb} / \mathrm{ft}^{3}$, max. for coarse aggregate) for use as lightweight aggregate in CMU production. However, the aggregates produced from Test No. FGD-LM-OS-1 to FGD-LM-OS-4 met AASHTO LA abrasion (40\%, max.) and soundness (12\% max.) indices specifications for use as coarse aggregate in road construction.

The aggregate produced from Test No. FGD-LM-OS-4 was selected for use in the aggregate durability study in Task 4 .

Fixated With Low and High LOI Fly Ash. As shown in Table 2-B-3, three pelletization tests (Test Nos. FGD-LM-OS-2-1 to FGD-LM-OS-2-3) were conducted to evaluate the effects of mix formulation and low and high LOI fly ash addition on properties of aggregates made from fixated lime wet FGD materials. FGD filter cake and low LOI fly ash $(1.51 \%$ LOI in Table 1-B) with high specific gravity (2.456 in Table 1-B) were collected from AEP Conesville Station in Ohio. High LOl fly ash (15.63\%, Table 1-D) 
with low specific gravity (1.971, Table 1-D) was collected from First Energy Sammis station in Ohio. Mixer feed, operating conditions and properties of aggregates are listed in the table for comparison. In Test No. FGD-LM-OS-2-1, aggregate products were made from FGD filter cake, low LOI Conesville fly ash hydrated lime and water. The aggregate produced had a crush strength of $130 \pm 26 \mathrm{lb}$, unit weights of $65.3 \mathrm{lb} / \mathrm{ft}^{3}$ (as-is) and $56.8 \mathrm{lb} / \mathrm{ft}^{3}$ (dry). In Test Nos. FGD-LM-OS-2-2 and FGD-LM-OS-2-3, 25\% and $50 \%$ of low LOI Conesville fly ash were replaced with high LOI Sammis fly ash in mix feed. The aggregates produced had crush strengths of $184 \pm 28$ and $186 \pm 36 \mathrm{lb}$, respectively. Unit weights decreased to $63.5 \mathrm{lb} / \mathrm{ft}^{3}$ (as-is) and $54.4 \mathrm{lb} / \mathrm{ft}^{3}$ (dry) in Test No.FGD-LM-OS-2-2 and to $61.9 \mathrm{lb} / \mathrm{ft}^{3}$ (as-is) and $52.0 \mathrm{lb} / \mathrm{ft}^{3}$ (dry) in Test No. FGD-LMOS-2-3. In all tests, unit weights were determined with crushed aggregates meeting ASTM No. 8 and 9 size gradation (combined fine and coarse aggregates).

Test results show that aggregates produced had adequate crush strength and unit weight for use as lightweight aggregate in CMU production. The unit weight decreased with increasing amount of high LOI and low specific gravity Sammis fly ash addition in mix feed. At 50/50 Conesville and Sammis Station fly ash with combined LOI of $8.57 \%$ (Test No. FGD-LM-OS-2-3), aggregate produced had a crush strength of $186 \pm 36 \mathrm{lb}$. The crush strength was higher than that $(130 \pm 26 \mathrm{lb})$ of the aggregate produced with $100 \%$ Conesville Station fly ash with LOI of $1.51 \%$. In comparison, the aggregate produced from fixated lime wet FGD materials with high LOI fly ash (22.93\% of LOI), as shown in Table 2-B-1, had low crush strength of $97 \pm 31 \mathrm{lb}$. This indicates that aggregate strength may improve with addition of fly ash with moderate increase in LOI, but not with high LOI.

In a separate project, funded by OCDO, ${ }^{1,2}$ lightweight aggregate was produced from the pilot plant operation and was used in block production demonstration tests. The mix formulation and operating conditions used in the pilot plant demonstration were similar to those used in Test No. FGD-LM-OS-2-3. The aggregate produced from the pilot plant was selected for use in the aggregate products durability study in Task 5.

\section{FBC Ash}

FBC Ash from Low Sulfur Texas Lignite. As shown in Table 2-C-1, three pelletization tests (Test Nos. FBC-TS-1 to FBC-TS-3) were conducted to evaluate the effect of mix formulation and operating conditions on properties of aggregates made with FBC ash from New Mexico Power TNP One Station. Mixer feed, operating conditions and properties of aggregates are listed in the table for comparison. The FBC ash was generated from a low-sulfur Texas lignite. In Test Nos. FBC-TS-1 to FBC-TS3 ,.aggregate products were made from $\mathrm{FBC}$ ash and water with mixing time increased from 20 minutes to 25 minutes and to 30 minutes. The aggregates produced had crush strengths of $347 \pm 157 \mathrm{lb}, 279 \pm 102 \mathrm{lb}$ and $329 \pm 78 \mathrm{lb}$, and unit weights of $70.8 \mathrm{lb} / \mathrm{ft}^{3}, 66.5$ $\mathrm{lb} / \mathrm{ft}^{3}$ and $65.9 \mathrm{lb} / \mathrm{ft}^{3}$ (as-is) and $63.2 \mathrm{lb} / \mathrm{ft}^{3}, 58.7 \mathrm{lb} / \mathrm{ft}^{3}$ and $58.2 \mathrm{lb} / \mathrm{ft}^{3}$ (dry), respectively. In all tests, unit weights were determined with crushed aggregates meeting ASTM No. 8 and 9 size gradation (combined fine and coarse aggregates). 
Test results show that the aggregates produced had high crush strengths (over $200 \mathrm{lb}$ ) and adequate unit weights meeting ASTM C 331 lightweight aggregate specifications for use in CMU production. The high strength aggregates may be used in road construction.

The aggregate made from Test No. FBC-TS-3 was selected for use in the aggregate durability study in Test 4 .

FBC Ash from Low-Sulfur Coal. As shown in Table 2-C-2, two pelletization tests (Test Nos. FBC-PR-1 and FBC-PR-2) and one extrusion test (Test No. FBC-PR-3) were conducted to evaluate mix formulation and operating conditions on properties of aggregates made with FBC ash from AES Guayama Station in Puerto Rico. Mixer feed, operating conditions and properties of aggregates are listed in the table for comparison.. The FBC ash was generated from a low-sulfur Columbia coal. In Test Nos. FBC-PR-1 and FBC-PR-2, aggregates products were made from FBC ash and water with mixing time of 20 and 30 minutes. The aggregates produced had crush strengths of $203 \pm 55 \mathrm{lb}$ and $245 \pm 65 \mathrm{lb}$ and unit weights of $69.5 \mathrm{lb} / \mathrm{ft}^{3}$ and $65.0 \mathrm{lb} / \mathrm{ft}^{3}$ (as-is) and $60.3 \mathrm{lb} / \mathrm{ft}^{3}$ and $55.5 \mathrm{lb} / \mathrm{ft}^{3}$ (dry). In Test No. FBC-PR-3, the aggregate produced from extrusion with 26 minute mixing time had a crush strength of $708 \pm 120 \mathrm{lb}$ and unit weights of $62.0 \mathrm{lb} / \mathrm{ft}^{3}$ (as-is) and $54.2 \mathrm{lb} / \mathrm{ft}^{3}$ (dry). In extrusion, the crush strength was determined with cylindrical extruded products with lengths of 1.5 " to 1.7 " and diameter of 1". In disk pelletization, the crush strength was determined with spherical palletized products with $1 / 2 " \times 3 / 8$ " diameters. In all tests, unit weights were determined with crushed aggregates meeting No. 8 and 9 size gradation (combined fine and coarse aggregates).

The aggregates produced had strong crush strengths meeting the requirements of 100 $\mathrm{lb}$ (min.) for pelletized products and $400 \mathrm{lb}$ (min.) for extruded products, and had adequate dry unit weights meeting ASTM C331 specification (65 lb/ $\mathrm{ft}^{3}$, max.) for use as lightweight aggregate in CMU production.

The aggregates produced from Test No. FBC-PR-3 was selected for use in the aggregate durability study in Task 4 .

FBC Ash from Low-Sulfur Mississippi Lignite. As shown in Table 2-C-3, two pelletization tests (Test Nos. FBC-MS-1 and FBC-MS-2) and one extrusion test (Test No. FBC-MS-3) were conducted to evaluate the effects of mix formulation on properties of aggregates made with FBC ash from Tractebel Power Red Hills Station in Mississippi. Mixer feed, operating conditions and properties of aggregates are listed in the table for comparison. The FBC ash was generated from a low-sulfur Mississippi lignite. In Test Nos. FBC-MS-1 and FBC-MS-2, aggregate products were made from FBC ash and water with mixing time of 20 and 30 minutes. The aggregates produced had crush strengths of $179 \pm 35 \mathrm{lb}$ and $211 \pm 89 \mathrm{lb}$. The aggregate produced in Test No. FBC-MS-2 had unit weights of $63.8 \mathrm{lb} / \mathrm{ft}^{3}$ (as-is) and $53.7 \mathrm{lb} / \mathrm{ft}^{3}$ (dry). In Test No. FBCMS-3, the aggregates produced from extrusion with 20 minute mixing time had crush strengths of $467 \pm 42 \mathrm{lb}$ and unit weights of $62.4 \mathrm{lb} / \mathrm{ft}^{3}$ (as-is) and $55.2 \mathrm{lb} / \mathrm{ft}^{3}$ (dry). In all 
tests, unit weights were determined with crushed aggregates meeting No. 8 and 9 size gradation (combined fine and coarse aggregates).

As in the Guayama Station FBC ash aggregate, the aggregates produced from Red Hill Station FBC ash had adequate crush strength and unit weights for use as lightweight aggregates in CMU production.

The aggregates produced from Test No. FBC-MS-3 was selected for use in the aggregate durability study in Task 4 .

FBC Ash from High Sulfur Coal. As shown in Table 2-C-4, three pelletization tests (Test Nos. FBC-FS-1 to FBC-FS-3) and one extrusion test (Test No. FBC-FS-4) were conducted to evaluate the effects of mix formulation and fly ash addition on properties of aggregates made with FBC ash from JEA Northside Station in Florida and with fly ash (Class F) from Lakeland Mclntosh Station in Florida. Mixer feed, operating conditions and properties of aggregates are listed in the table for comparison. The FBC ash was generated from a $30 / 70$ blend of high-sulfur coal (3\% S) and petcoke (6.4\% S). In Test No. FBC-FS-1, aggregate was made from FBC ash with mixing time of 20 minutes. The aggregate produced had a crush strength of $240 \pm 80 \mathrm{lb}$. In Test Nos. FBC-FS-2 and FBC-FS-3, $10 \%$ and $30 \%$ of Lakeland fly ash were added in the mix feed. The aggregates produced had crush strengths of $221 \pm 72 \mathrm{lb}$ and $348 \pm 112 \mathrm{lb}$, respectively. Unit weights and size gradation were not determined in these tests. In Test No. FBCFS-4, the aggregate produced from extrusion with 20 minute mixing time had a crush strength of $420 \pm 123 \mathrm{lb}$ and unit weights of $61.4 \mathrm{lb} / \mathrm{ft}^{3}$ (as-is) and $55.4 \mathrm{lb} / \mathrm{ft}^{3}$ (dry).

As in aggregates produced from low-sulfur coal FBC ash, the aggregate produced from high-sulfur coal FBC ash had adequate crush strength and unit weight for use as lightweight aggregate in $\mathrm{CMU}$ production.

The aggregates produced from Test Nos. FBC-FS-1 to FBC-FS-3 with and without fly ash addition in mix feed were selected for use in the aggregate durability study in Task 4.

FBC Ash from Waste Coal. As shown in Table 2-C-5, two pelletization tests were conducted to evaluate the mix formulation and operating conditions on properties of aggregate made with FBC ash from PG\&E Northampton Station in Pennsylvania. Mixer feed, operating conditions and properties of aggregates are listed in the table for comparison. The FBC ash was generated from waste coal (or gob). In Test Nos. FBCPS-1 and FBC-PS-2, aggregates produced had crush strengths of $301 \pm 52 \mathrm{lb}$ and $298 \pm 72 \mathrm{lb}$ and unit weights of $65.4 \mathrm{lb} / \mathrm{ft}^{3}$ and $68.2 \mathrm{lb}^{3}$ (as-is) and $54,0 \mathrm{lb} / \mathrm{ft}^{3}$ and 60.0 $\mathrm{lb} / \mathrm{ft}^{3}$ (dry), respectively. Unit weights were determined with crush aggregates meeting ASTM No. 8 and 9 size gradation (combined fine and coarse aggregates).

The aggregates produced had adequate crush strengths and unit weights for use as lightweight aggregate in CMU production. Since there is no significant differences in 
crush strength and unit weight with aggregates produced from other low-sulfur coal FBC ash, these aggregates were not used for the durability study.

\section{Pulverized Coal Fly Ash}

Class F and Class C Fly Ash. As shown in Table 2-D-2, three pelletization tests (Test Nos. FY-FS-1 to FY-FS-3) were conducted to evaluate the effects of mix formulation and Class $F$ and Class $C$ fly ash addition on properties of aggregates made from pulverized coal fly ash only. The Class $F$ fly ash was collected from JEA Seminole Station in Florida,. The Class C fly ash was collected from GPCO Scherer Station in Georgia. Mixer feed, operating conditions and properties of aggregates are listed in the table for comparison. In Test Nos. FY-FS-1 and FY-FS-2, aggregate products were made from Class $F$ fly ash, hydrated lime and water with slightly different mix ratios. The aggregates produced had crush strengths of $103 \pm \mathrm{lb}$ and $113 \pm 28 \mathrm{lb}$ and unit weights of $72.6 \mathrm{lb} / \mathrm{ft}$ and $72.6 \mathrm{lb} / \mathrm{ft}^{3}$ (as-is) and $71.4 \mathrm{lb} / \mathrm{ft}^{3}$ and $66.5 \mathrm{lb} / \mathrm{ft}^{3}$ (dry). In Test No. FY-FS-3, $20 \%$ of Class F fly ash was replaced with Class $\mathrm{C}$ fly ash in mix feed. The aggregate produced had higher crush strength of $204 \pm 32 \mathrm{lb}$ and unit weights of 77.5 $\mathrm{lb} / \mathrm{ft}^{3}$ (as-is) and $72.8 \mathrm{lb} / \mathrm{ft}^{3}$ (dry). In all tests unit weights were determined with crushed aggregates meeting ASTM No. 8 and 9 size gradation.

Test results show that crush strength and unit weight of aggregate increased substantially with addition of Class $C$ fly ash. Dry unit weights of aggregates did not meet the ASTM C331 lightweight aggregate specification for use in CMU production, even without Class $\mathrm{C}$ fly ash addition. These aggregates were not selected for the durability study, because they did not meet the ASTM C331 specifications.

\section{Spray Dryer Ash}

Spray Dryer Ash with Class F Fly Ash. As shown in Table 2-E-1, three pelletization tests (Test Nos. SDA-VS-1 to SDA-VS-3) and one extrusion run (Test No. SDA-VS-4) were conducted to evaluate the effects of mix formulation and operating conditions on properties of aggregates made with spray dryer ash (SDA) from Birchwood Power Station in Virginia. The SDA contains Class $\mathrm{F}$ fly ash, which was generated from a lowsulfur bituminous coal. In Test No. SDA-VS-1, aggregate was made from SDA, hydrated lime and water. The aggregate produced had a crush strength of $181 \pm 61 \mathrm{lb}$ and unit weights of $58.6 \mathrm{lb} / \mathrm{ft}^{3}$ (as-is) and $51.6 \mathrm{lb} / \mathrm{ft}^{3}$ (dry). In Test Nos. SDA-VS-2 and SDA-VS$2,3 \%$ and $6 \%$ of cement (based on dry basis) were added in the mix feeds. The aggregates produced had crush strengths of $181 \pm 39 \mathrm{lb}$ and $150 \pm 46 \mathrm{lb}$, unit weights of $59.2 \mathrm{lb} / \mathrm{ft}^{3}$ and $59.2 \mathrm{lb} / \mathrm{ft}^{3}$ (as-is) and $49.0 \mathrm{lb} / \mathrm{ft}^{3}$ and $51.0 \mathrm{lb} / \mathrm{ft}^{3}$ (dry), respectively. In Test No. SDA-VS-4, the aggregate produced from extrusion had a crush strength of $484 \pm 106$ $\mathrm{lb}$ and unit weights of $54.2 \mathrm{lb} / \mathrm{ft}^{3}$ (as-is) and $47.8 \mathrm{lb} / \mathrm{ft}^{3}$ (dry). In extrusion, the crush strength was determined with cylindrical extruded products with lengths of 1.5 " to 1.7" and diameter of 1". In disk pelletization, the crush strength was determined with spherical pelletized products with $1 / 2 " \times 3 / 8$ " diameters. In all tests, unit weights were determined with crushed aggregates meeting ASTM No. 8 and 9 size gradation (combined fine and coarse aggregates). 
Test results show that aggregates produced from the above tests had adequate crush strength and unit weight for use as lightweight aggregate in CMU production. Addition of cement in mix feed did not increase the aggregate crush strength.

The aggregates produced from Test Nos. SDA-VS-1 and SDA-VS-3 were used to study the effects of cement addition in the durability study.

In a separate project, internally funded by Universal Aggregates, lightweight aggregate was produced in the pilot plant and used in block production demonstration. The mix formulation and operation conditions used in the pilot plant were similar to those used in Test No. SDA-VS-4. The aggregate produced from the pilot plant was selected for use in the aggregate products durability study.

Spray Dryer Ash with Class C Fly Ash. As shown in Table 2-E-2, three pelletization tests (Test Nos. SDA-KS-1 to SDA-KS-3) were conducted to evaluate the effect of mix formulation and operating conditions on properties of aggregates made with SDA from Sunflower Power Station in Kansas. Mixer feed, operating conditions and properties of aggregates are listed in the table for comparison. The SDA contained Class $\mathrm{C}$ fly ash, which was generated from a low-sulfur subbituminous coal. In Test No. SDA-KS-1, aggregate was made from SDA, hydrated lime and water with 4 minute mixing time. The aggregate produced had a crush strength of $177 \pm 69 \mathrm{lb}$ and unit weights of 73.4 $\mathrm{lb} / \mathrm{ft}^{3}$ (as-is) and $67.4 \mathrm{lb} / \mathrm{ft}^{3}$ (dry). In Test Nos. SDA-KS-2 and SDA-KS-3, the mixing time was increased to 20 minutes. The aggregates produced had crush strengths of $221 \pm 67 \mathrm{lb}$ and $204 \pm 56 \mathrm{lb}$ and unit weights of $74.1 \mathrm{lb} / \mathrm{ft}^{3}$ and $74.0 \mathrm{lb} / \mathrm{ft}^{3}$ (as-is) and 67.2 $\mathrm{lb} / \mathrm{ft}^{3}$ and $67.1 \mathrm{lb} / \mathrm{ft}^{3}$ (dry), respectively. In all tests unit weights were determined with crushed aggregates meeting ASTM No. 8 and 9 size gradation (combined fine and coarse aggregates).

Test results show that aggregate with high crush strength (over $200 \mathrm{lb}$ ) can be produced from SDA with Class $C$ fly ash and 20 minute mixing time. However, dry unit weights produced did not meet the ASTM C331 specification (i.e., $65 \mathrm{lb} / \mathrm{ft}^{3}$, max. for combined aggregate) for use as lightweight aggregate in CMU production. The strong aggregate may be used in road construction.

The aggregates made from Test Nos. SDA-KS-1 and SDA-KS-3 with different mixing time were selected for use in the durability study in Task 4. 
Table 2-A-1. Test Conditions and Properties of Pelletized Products Made with Fixated Wet Limestone Materials from Reliant Energy Limestone Station in Texas (Limestone Wet FGD with Class C Fly Ash)

\begin{tabular}{|c|c|c|c|c|}
\hline "Test Nos. FGD-LS-TS- & 1 & 2 & 3 & 4 \\
\hline Mixer Feed, wt $\%$ & & & & \\
\hline FGD Filter Cake, as-is & 37.1 & 37.8 & 37.4 & 38.0 \\
\hline Lignite Fly Ash & 54.3 & 55.1 & 27.3 & 0 \\
\hline Subbituminous Fly Ash (Class & 0 & 0 & 27.3 & 58.2 \\
\hline C) & 5.2 & 6.1 & 6.0 & 5.8 \\
\hline Hydrated Lime & 3.4 & 1.0 & 2.0 & 3.0 \\
\hline$\underline{\text { Mixing Time, } \min }$ & 4.0 & 4.0 & 4.0 & 8.0 \\
\hline Pelletizer Feed & ca. 13.4 & ca. 13.4 & ca. 13.4 & ca. 13.4 \\
\hline $\begin{array}{l}\text { Feed Rate, lb/min } \\
\text { Water Added, wt } \%\end{array}$ & 3.4 & 0 & 0 & 0 \\
\hline Pelletization Time, $\min$ & ca. 25 & ca. 25 & ca. 25 & ca. 20 \\
\hline Curing Temperature, ${ }^{\circ} \mathrm{F}$ & $160-170$ & $160-170$ & $160-170$ & $160-170$ \\
\hline$\frac{\text { Product Properties }}{\text { Crush Strength, Ib }}$ & $79 \pm 11$ & $90 \pm 10$ & $226 \pm 78$ & $246 \pm 45$ \\
\hline Unit Weight, $\mathrm{lb} / \mathrm{ft}^{3}$ & 69.9 & 72.9 & 74.0 & 75.2 \\
\hline $\begin{array}{l}\text { as-is } \\
\text { dry }\end{array}$ & $\begin{array}{c}63.4 \\
\text { Nos. } 8 / 9\end{array}$ & $\begin{array}{l}68.1 \\
\text { Nos. } 8 / 9\end{array}$ & $\begin{array}{c}68.3 \\
\text { Nos. } 8 / 9\end{array}$ & $\begin{array}{l}69.6 \\
\text { Nos } 8 / 9\end{array}$ \\
\hline Particle Size, wt $\%$ pass & (Combined) & (Combined) & (Combined) & (Combined) \\
\hline
\end{tabular}


Table 2-A-2. Test Conditions and Properties of Pelletized Products Made with Fixated Limestone FGD Materials from Lakeland Mclntosh Station in Florida (Limestone Wet FGD with Class F Fly Ash)

\begin{tabular}{|c|c|c|c|c|}
\hline Test Nos. FGD-LS-FS- & 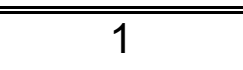 & 2 & 3 & 4 (a) \\
\hline Mixer Feed, wt $\%$ & & & & \\
\hline 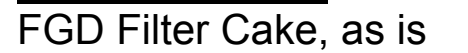 & 26.4 & 47.0 & 40.0 & 39.7 \\
\hline Fly Ash (Class F) & 40.7 & 47.0 & 44.0 & 43.2 \\
\hline Bottom Ash & ---- & ---- & 10.0 & 8.5 \\
\hline Hydrated Lime & 4.4 & 6.0 & 6.0 & 6.0 \\
\hline Water & 28.6 & 0 & 0 & 2.6 \\
\hline Mixing Time, min & 4.0 & 4.0 & 4.0 & 4.0 \\
\hline Pelletizer Feed & & & & \\
\hline $\begin{array}{l}\text { Feed Rate, } \mathrm{lb} / \mathrm{m} \text { in } \\
\text { Water Added, } \mathrm{lb}\end{array}$ & $\begin{array}{c}\text { ca. } 13.4 \\
0\end{array}$ & $\begin{array}{c}\text { ca. } 13.4 \\
0\end{array}$ & $\begin{array}{c}\text { ca. } 13.4 \\
0\end{array}$ & $\begin{array}{c}\text { ca. } 13.4 \\
0\end{array}$ \\
\hline Pelletization Time, min & ca. 25 & ca. 20 & ca. 20 & ca. 20 \\
\hline Curing Temperature, ${ }^{\circ} \mathrm{F}$ & $160-170$ & $160-170$ & $160-170$ & $160-170$ \\
\hline Product Properties & & & & \\
\hline $\begin{array}{l}\text { Crush Strength, Ib } \\
\text { Unit Weight, } \mathrm{lb} / \mathrm{ft}^{3}\end{array}$ & $164 \pm 40$ & $143 \pm 36$ & $121 \pm 24$ & $464 \pm 43(b)$ \\
\hline As-is & 61.2 & 65.0 & 64.3 & 64.6 \\
\hline Dry & 54.0 & 56.8 & 55.7 & 55.6 \\
\hline Soundness Index, \% & ---- & 21.6 & ---- & --- \\
\hline Particle Size, wt $\%$ pass & $\begin{array}{c}\text { Nos. 8/9 } \\
\text { (Combined) }\end{array}$ & $\begin{array}{c}\text { Nos. 8/9 } \\
\text { (Combined) }\end{array}$ & $\begin{array}{c}\text { Nos. 8/9 } \\
\text { (Combined) }\end{array}$ & $\begin{array}{c}\text { Nos. 8/9 } \\
\text { (Combined) }\end{array}$ \\
\hline
\end{tabular}

(a) Produced by extrusion run

(b) Average of ten measurements with extruded products with lengths of 1.5" to 1.7" and diameter of 1" 
Table 2-B-1. Test Conditions and Properties of Pelletized Products Made with Fixated Wet Lime FGD Materials from Reliant Energy's Elrama Station in Pennsylvania (Lime Wet FGD with High LOI Fly Ash)

\begin{tabular}{|c|c|c|c|}
\hline Test Nos. FGD-LM-PS- & 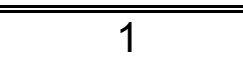 & 2 & 3 \\
\hline Mixer Feed, wt $\%$ & & & \\
\hline$\overline{\text { FGD Filter Cake }}$ & 42.7 & 60.3 & 60.1 \\
\hline Fly Ash & 42.3 & 33.2 & 33.1 \\
\hline Lime & 4.0 & 4.0 & ---- \\
\hline Hydrated Lime & --- & ---- & 5.2 \\
\hline Water & 11.0 & 2.5 & 1.6 \\
\hline Mixing Time, min & 2.0 & 2.0 & 4.0 \\
\hline Pelletizer Feed & & & \\
\hline $\begin{array}{l}\text { Feed Rate, Ib/min } \\
\text { Water Added, wt } \%\end{array}$ & $\begin{array}{c}\text { ca. } 13.4 \\
2.4\end{array}$ & $\begin{array}{c}\text { ca. } 13.4 \\
0.48\end{array}$ & $\begin{array}{c}\text { ca. } 13.4 \\
0\end{array}$ \\
\hline Pelletization Time, min & ca. 25 & ca. 25 & ca. 25 \\
\hline Curing Temperature, ${ }^{\circ} \mathrm{F}$ & $160-170$ & $160-170$ & $160-170$ \\
\hline Product Properties & & & \\
\hline $\begin{array}{l}\text { Crush Strength, lb } \\
\text { LA Abrasion Index, \% } \\
\text { Unit Weight, lb/ft }{ }^{3}\end{array}$ & $\begin{array}{c}37 \pm 12 \\
59.9\end{array}$ & $\begin{array}{c}58 \pm 19 \\
42.6\end{array}$ & $\begin{array}{c}97 \pm 31 \\
34.6\end{array}$ \\
\hline $\begin{array}{l}\text { as-is } \\
\text { dry }\end{array}$ & $\begin{array}{l}55.3 \\
51.4\end{array}$ & $\begin{array}{l}58.3 \\
53.1\end{array}$ & $\begin{array}{l}63.9 \\
57.5\end{array}$ \\
\hline Soundness Index, \% & -- & --- & 81.0 \\
\hline Particle Size, wt\% pass & $\begin{array}{c}\text { Nos. 8/9 } \\
\text { (Combined) }\end{array}$ & $\begin{array}{c}\text { Nos. 8/9 } \\
\text { (Combined) }\end{array}$ & $\begin{array}{c}\text { Nos. 8/9 } \\
\text { (Combined) }\end{array}$ \\
\hline
\end{tabular}


Table 2-B-2. Test Conditions and Properties of Pelletized Products Made with Fixated FGD Materials from AEP Gavin Station in Ohio (Lime Wet FGD with Low LOI Fly Ash)

\begin{tabular}{|c|c|c|c|c|}
\hline Test Nos. FGD-LM-OS-1- & 1 & 2 & 3 & 4 \\
\hline \multicolumn{5}{|l|}{ Mixer Feed, wt $\%$} \\
\hline$\overline{\text { FGD Sludge, as is }}$ & 43.9 & 43.0 & 41.6 & 43.0 \\
\hline Fly Ash & 52.0 & 51.4 & 45.6 & 38.2 \\
\hline Lime & 4.1 & --- & ---- & 0 \\
\hline Hydrated Lime & ---- & 5.6 & 12.8 & 5.6 \\
\hline Cement & ---- & ---- & ---- & 13.2 \\
\hline Water & 0 & 0 & 0 & 0 \\
\hline Mixing Time, $\min$ & 4.0 & 4.0 & 4.0 & 4.0 \\
\hline \multicolumn{5}{|l|}{ Pelletizer Feed } \\
\hline Feed Rate, Ib/min & ca. 13.4 & ca. 13.4 & ca. 13.4 & ca. 13.4 \\
\hline Water Added, wt $\%$ & 0 & 0 & 0 & 0 \\
\hline Pelletization Time, min & ca. 25 & ca. 25 & ca. 25 & ca. 25 \\
\hline Curing Temperature, ${ }^{\circ} \mathrm{F}$ & $160-170$ & $160-170$ & $160-170$ & $160-170$ \\
\hline \multicolumn{5}{|l|}{ Product Properties } \\
\hline $\begin{array}{l}\text { Crush Strength, lb } \\
\text { LA Abrasion Index, \% } \\
\text { Unit Weight, lb/ft }\end{array}$ & $\begin{array}{c}78 \pm 29 \\
51\end{array}$ & $\begin{array}{c}106 \pm 26 \\
45\end{array}$ & $\begin{array}{c}123 \pm 49 \\
42\end{array}$ & $\begin{array}{c}232 \pm 88 \\
30\end{array}$ \\
\hline as-is & 73.7 & 72.3 & 74.3 & 75.8 \\
\hline dry & 66.3 & 65.1 & 66.8 & 68.1 \\
\hline Soundness Index, \% & 49 & 46 & 79 & 5 \\
\hline \multicolumn{5}{|l|}{ Particle Size, wt $\%$ pass } \\
\hline $1 "$ & 98.0 & 93.5 & 93.4 & 96.5 \\
\hline 3/4" & 86.1 & 78.3 & 75.8 & 85.1 \\
\hline 1/2" & 49.9 & 46.3 & 43.6 & 50.3 \\
\hline 3/8" & 18.2 & 28.8 & 26.5 & 25.1 \\
\hline 4 mesh & 9.4 & 12.8 & 9.8 & 8.7 \\
\hline 8 mesh & 7.1 & 2.7 & 5.9 & 5.3 \\
\hline
\end{tabular}


Table 2-B-3. Test Conditions and Properties of Pelletized Products Made with Fixated Wet Lime FGD Materials from AEP Conesville Station in Ohio (Lime Wet FGD with High and Low LOI Fly Ash)

\begin{tabular}{|c|c|c|c|}
\hline Test Nos. FGD-LM-OS-2- & 1 & 2 & 3 \\
\hline \multicolumn{4}{|l|}{ Mixer Feed, wt $\%$} \\
\hline FGD Filter Cake, as is & 39.5 & 39.3 & 41.1 \\
\hline Conesville Fly Ash (Low LOI) & 54.5 & 40.7 & 26.7 \\
\hline Sammis Fly Ash (High LOI) & 0 & 13.5 & 26.2 \\
\hline Hydrated Lime & 6.0 & 6.0 & 6.0 \\
\hline Water & 0 & 0.5 & 0.5 \\
\hline Mixing Time, $\min$ & 8.0 & 4.0 & 4.0 \\
\hline \multicolumn{4}{|l|}{ Pelletizer Feed } \\
\hline$\overline{\text { Feed Rate, lb/min }}$ & ca. 13.4 & ca. 13.6 & ca. 13.4 \\
\hline Water Added, wt $\%$ & 0 & 0 & 0 \\
\hline Pelletization Time, min & ca. 25 & ca. 25 & ca. 25 \\
\hline Curing Temperature, $\mathrm{F}$ & $160-170$ & $160-170$ & $160-170$ \\
\hline \multicolumn{4}{|l|}{ Product Properties } \\
\hline $\begin{array}{l}\text { Crush Strength, } \mathrm{lb} \\
\text { Unit Weight, } \mathrm{lb} / \mathrm{ft}^{3}\end{array}$ & $130 \pm 26$ & $184 \pm 28$ & $186 \pm 36$ \\
\hline as-is & 65.3 & 63.5 & 61.9 \\
\hline dry & 56.8 & 54.4 & 52.0 \\
\hline Particle Size, wt $\%$ pass & $\begin{array}{c}\text { Nos. } 8 / 9 \\
\text { (Combined) }\end{array}$ & $\begin{array}{c}\text { Nos. 8/9 } \\
\text { (Combined) }\end{array}$ & $\begin{array}{c}\text { Nos. 8/9 } \\
\text { (Combined) }\end{array}$ \\
\hline
\end{tabular}


Table 2-C-1. Test Conditions and Properties of Pelletized Products Made with Low Sulfur FBC Ash from New Mexico Power TNP One Station (FBC Ash from Low Sulfur Texas Lignite)

\begin{tabular}{|c|c|c|c|}
\hline Test Nos. FBC-TS- & 1 & 2 & 3 \\
\hline \multicolumn{4}{|l|}{ Mixer Feed, wt\% } \\
\hline FBC Ash & 70.9 & 70.9 & 71.4 \\
\hline Water & 29.1 & 29.1 & 28.6 \\
\hline Mixing Time, $\min$ & 20 & 25 & 30 \\
\hline \multicolumn{4}{|l|}{ Pelletizer Feed } \\
\hline Feed Rate, $\mathrm{Ib} / \mathrm{min}$ & ca. 13.4 & ca. 13.4 & ca. 13.4 \\
\hline Water Added, wt $\%$ & 0 & 0 & 0 \\
\hline Pelletization Time, min & ca. 25 & ca. 30 & ca. 30 \\
\hline$\underline{\text { Curing Temperature, }{ }^{\circ} \mathrm{F}}$ & $160-170$ & $160-180$ & $160-170$ \\
\hline \multicolumn{4}{|l|}{ Product Properties } \\
\hline $\begin{array}{l}\text { Crush Strength, lb } \\
\text { Unit Weight, } \mathrm{lb} / \mathrm{ft}^{3}\end{array}$ & $347 \pm 157$ & $279 \pm 102$ & $329 \pm 78$ \\
\hline As-is & 70.8 & 66.5 & 65.9 \\
\hline Dry & 63.2 & 58.7 & 58.2 \\
\hline Particle Size, wt $\%$ pass & $\begin{array}{c}\text { No. 8/9 } \\
\text { (Combined) }\end{array}$ & $\begin{array}{c}\text { No. 8/9 } \\
\text { (Combined) }\end{array}$ & $\begin{array}{c}\text { No. 8/9 } \\
\text { (Combined) }\end{array}$ \\
\hline
\end{tabular}


Table 2-C-2. Test Conditions and Properties of Pelletized Products Made with Low Sulfur FBC Ash from AES Guayama Station in Puerto Rico (FBC Ash from Low Sulfur Coal)

\begin{tabular}{||l|c|c|c|}
\hline \hline Test Nos. FBC-PR- & $\mathbf{1}$ & $\mathbf{2}$ & $\mathbf{3}$ (a) \\
\hline Mixer Feed, wt\% & & & 73.7 \\
\hline FBC Ash & 74.5 & 71.5 & 26.3 \\
Water & 25.5 & 28.5 & 26 \\
Mixing Time, min & 20 & 30 & \\
Pelletizer Feed & & & ca. 13.4 \\
\hline Feed Rate, lb/min & ca. 13.4 & ca. 13.4 & 0 \\
Water Added, wt\% & 0 & & ca. 25 \\
Pelletization Time, min & ca. 25 & ca. 25 & $160-170$ \\
\hline Curing Temperature, ${ }^{\circ}$ F & $160-170$ & $160-170$ & \\
Product Properties & & & $708 \pm 120$ (b) \\
\hline Crush Strength, lb & $203 \pm 55$ & $245 \pm 65$ & 62.0 \\
Unit Weight, lb/ft ${ }^{3}$ & 69.5 & 65.0 & 54.2 \\
As-is & 60.3 & 55.5 & No. $8 / 9$ \\
Dry & No. $8 / 9$ & No. $8 / 9$ & (Combined) \\
Particle Size, wt\% pass & (Combined) & (Combined) & \\
\hline
\end{tabular}

(a) Produced by Extrusion run

(b) Average of ten measurements of extruded products with lengths of 1.5 " to 1.7" and diameter of 1 " 
Table 2-C-3. Test Conditions and Properties of Pelletized and Extruded Products Made with Low Sulfur FBC Ash from Tractebel Power Red Hills Station in Mississippi (FBC Ash from Low Sulfur Lignite)

\begin{tabular}{|c|c|c|c|}
\hline Test Number FBC-MS- & 1 & 2 & 3 (a) \\
\hline \multicolumn{4}{|l|}{ Mixer Feed wt\% } \\
\hline FBC Ash & 70.6 & 70.2 & 69.6 \\
\hline Water & 29.6 & 29.8 & 30.4 \\
\hline Mixing Time, $\min$ & 20 & 30 & 20 \\
\hline \multicolumn{4}{|l|}{ Pelletizer Feed } \\
\hline Feed Rate, Ib/min & ca. 13.4 & ca. 13.4 & ca. 13.4 \\
\hline Water Added, Ib & 0 & 0 & 0 \\
\hline Pelletization Time, min & 20 & 20 & 20 \\
\hline Curing Temperature, ${ }^{\circ} \mathrm{F}$ & $160-170$ & $160-170$ & $160-170$ \\
\hline \multicolumn{4}{|l|}{ Product Properties } \\
\hline $\begin{array}{l}\text { Crush Strength, lb } \\
\text { Unit Weight } \mathrm{lb} / \mathrm{ft}^{3}\end{array}$ & $179 \pm 35$ & $211 \pm 89$ & $467 \pm 42$ (b) \\
\hline As-is & --- & 63.8 & 62.4 \\
\hline Dry & ---- & 53.7 & 55.2 \\
\hline Particle Size, wt $\%$ pass & $\begin{array}{c}\text { Nos. 8/9 } \\
\text { (Combined) }\end{array}$ & $\begin{array}{c}\text { Nos. 8/9 } \\
\text { (Combined) }\end{array}$ & $\begin{array}{c}\text { Nos. 8/9 } \\
\text { (Combined) }\end{array}$ \\
\hline
\end{tabular}

(a) Produced by extrusion run

(b) Average of ten measurements of extruded products with lengths of 1.5 " to 1.7" and diameter of 1 " 
Table 2-C-4. Test Conditions and Properties of Pelletized and Extruded Products Made with High Sulfur FBC Ash from JEA Northside Station in Florida (FBC Ash from High Sulfur Coal and Coke)

\begin{tabular}{|c|c|c|c|c|}
\hline Test Nos. FBC-FS & 1 & 2 & 3 & 4 (a) \\
\hline \multicolumn{5}{|l|}{ Mixer Feed, wt\% } \\
\hline FBC ash & 73.9 & 67.5 & 53.2 & 72.7 \\
\hline Lakeland Fly Ash (p. c.) & 0 & 7.5 & 22.8 & 0 \\
\hline Water & $26.1^{\circ}$ & 25.0 & 24.0 & 27.3 \\
\hline Mixing Time, min & 20 & 20 & 20 & 20 \\
\hline \multicolumn{5}{|l|}{ Pelletizer Feed } \\
\hline Feed Rate, Ib/min & ca. 13.4 & са. 13.4 & ca. 13.4 & ca. 13.4 \\
\hline Water Added, Ib & 0 & 0 & 0 & 0 \\
\hline Pelletization Time, min & ca. 25 & ca. 25 & ca. 25 & ca. 25 \\
\hline Curing Temperature, $F$ & $160-170$ & $160-170$ & $160-170$ & $160-170$ \\
\hline \multicolumn{5}{|l|}{ Product Properties } \\
\hline Crush Strength, Ib & $240 \pm 80$ & $221 \pm 72$ & $348 \pm 112$ & $420 \pm 123$ (b) \\
\hline As-is & ---- & ---- & ---- & 61.4 \\
\hline Dry & ----- & ---- & ---- & 55.4 \\
\hline Particle Size, wt $\%$ pass & ----- & ---- & ---- & $\begin{array}{c}\text { Nos. 8/9 } \\
\text { (Combined) }\end{array}$ \\
\hline
\end{tabular}

(a) Extrusion run

(b) Average of ten measurements of extruded products with lengths of 1.5 " to 1.7" and diameter of 1" 
Table 2-C-5. Test Conditions and Properties of Pelletized Products Made with Waste Coal FBC Ash from PG\&E Northampton Station in Pennsylvania (FBC Ash from Waste Coal)

\begin{tabular}{|c|c|c|}
\hline Test No. FBC-PS- & 1 & 2 \\
\hline \multicolumn{3}{|l|}{ Mixer Feed, wt\% } \\
\hline FBC Ash & 71.9 & 75.5 \\
\hline Water & 28.1 & 25.5 \\
\hline Mixing Time, $\min$ & 10 & 20 \\
\hline \multicolumn{3}{|l|}{ Pelletizer Feed } \\
\hline Feed Rate, Ib/min & ca. 13.4 & ca. 13.4 \\
\hline Water Added, lb & 0 & 0 \\
\hline Pelletization Time, min & ca. 25 & ca. 20. \\
\hline$\underline{\text { Curing Temperature, }{ }^{\circ} \mathrm{F}}$ & $160-170$ & $160-170$ \\
\hline \multicolumn{3}{|l|}{ Product Properties } \\
\hline Crush Strength, Ib & $301 \pm 52$ & $298 \pm 72$ \\
\hline Unit Weight, $\mathrm{lb} / \mathrm{ft}^{3}$ & & \\
\hline As-is & 65.4 & 68.2 \\
\hline Dry & 54.9 & 60.0 \\
\hline Particle Size, wt $\%$ pass & Nos. 8/9 & Nos. 8/9 \\
\hline
\end{tabular}


Table 2-D-1. Test Conditions and Properties of Pelletized Products Made with Class F Fly Ash from JEA Seminole Station in Florida and Class C Fly Ash from GPCO Scherer Station in Georgia (Class F and Class C Fly Ash)

\begin{tabular}{|c|c|c|c|}
\hline Test No. FY-FS- & 1 & 2 & 3 \\
\hline \multicolumn{4}{|l|}{ Mixer Feed, wt $\%$} \\
\hline Fly Ash (Class F) & 76.7 & 75.0 & 77.0 \\
\hline Fly Ash (Class C) & ---- & --- & 15.4 \\
\hline Hydrated Lime & 4.9 & 4.8 & 4.9 \\
\hline Water & 18.4 & 20.2 & 18.0 \\
\hline Mixing Time, $\min$ & 4.0 & 4.0 & 4.0 \\
\hline \multicolumn{4}{|l|}{ Pelletizer Feed } \\
\hline Feed Rate, Ib/min & ca. 13.4 & ca. 13.4 & ca. 13.4 \\
\hline Water Added, wt $\%$ & 0 & 0 & 0 \\
\hline Pelletization Time, min & ca. 20 & ca. 20 & ca. 20 \\
\hline Curing Temperature, ${ }^{\circ} \mathrm{F}$ & $160-170$ & $160-170$ & $160-170$ \\
\hline \multicolumn{4}{|l|}{ Product Properties } \\
\hline Crush Strength, lb & $103 \pm 67$ & $113 \pm 28$ & $204 \pm 32$ \\
\hline $\begin{array}{l}\text { Unit Weight, lb/ft } \\
\text { As-is }\end{array}$ & 75.5 & 72.6 & Unit Weight, $\mathrm{lb} / \mathrm{ft}^{3}$ \\
\hline Dry & 71.4 & 66.5 & 72.8 \\
\hline Particle Size, wt $\%$ pass & $\begin{array}{c}\text { Nos. 8/9 } \\
\text { (Combined) }\end{array}$ & $\begin{array}{c}\text { Nos. 8/9 } \\
\text { (Combined) }\end{array}$ & $\begin{array}{c}\text { Nos. 8/9 } \\
\text { (Combined) }\end{array}$ \\
\hline
\end{tabular}


Table 2-E-1. Test Conditions and Properties of Pelletized and Extruded Products Made with SDA Containing Class F Fly Ash from Birchwood Power Station in Virginia (Spray Dryer Ash with Class F Fly Ash)

\begin{tabular}{|c|c|c|c|c|}
\hline Test Nos. SDA-VS- & 1 & 2 & 3 & 4 (a) \\
\hline Mixer Feed, wt $\%$ & & & & \\
\hline$\overline{\text { Spray Dryer Ash }}$ & 68.8 & 66.4 & 64.6 & 69.6 \\
\hline Hydrated Lime & 4.3 & 4.2 & 4.3 & 4.5 \\
\hline Cement & ---- & 2.2 & 4.4 & ---- \\
\hline Water & 26.9 & 27.2 & 26.7 & 25.9 \\
\hline Mixing Time, $\min$ & 2.0 & 4.0 & 6.0 & 10 \\
\hline Pelletizer Feed & & & & \\
\hline $\begin{array}{l}\text { Feed Rate, } \mathrm{Ib} / \mathrm{min} \\
\text { Water Added, Ib }\end{array}$ & ca. 13.4 & ca. 13.4 & ca. 13.4 & ca. 13.4 \\
\hline Pelletization Time, $\min$ & ca. 20 & ca. 20 & ca. 20 & ca. 20 \\
\hline Curing Temperature, F & $160-170$ & $160-170$ & $160-170$ & $160-170$ \\
\hline Product Properties & & & & \\
\hline $\begin{array}{l}\text { Crush Strength, lb } \\
\text { Unit Weight, lb/ft }\end{array}$ & $187 \pm 61$ & $181 \pm 39$ & $150 \pm 46$ & $484 \pm 106(b)$ \\
\hline As-is & 58.6 & 59.2 & 59.2 & 54.2 \\
\hline Dry & 51.6 & 49.0 & 51.0 & 47.8 \\
\hline Particle Size, wt $\%$ pass & $\begin{array}{c}\text { Nos. 8/9 } \\
\text { (Combined) }\end{array}$ & $\begin{array}{c}\text { Nos. 8/9 } \\
\text { (Combined) }\end{array}$ & $\begin{array}{c}\text { Nos. 8/9 } \\
\text { (Combined) }\end{array}$ & $\begin{array}{c}\text { Nos. 8/9 } \\
\text { (Combined) }\end{array}$ \\
\hline
\end{tabular}

(a) Produced by extrusion run

(b) Average of ten measurements with extruded products with lengths of 1.5" to 1.7" and diameter of $1 "$ 
Table 2-E-2. Test Conditions and Properties of Pelletized Products Made with SDA Containing Class C Fly Ash from Sunflower Power Holcomb Station in Kansas (Spray Dryer Ash with Class C Fly Ash)

\begin{tabular}{|c|c|c|c|}
\hline Test Nos. SDA-KS- & 1 & 2 & 3 \\
\hline \multicolumn{4}{|l|}{ Mixer Feed, wt $\%$} \\
\hline$\overline{\text { Spray Dryer Ash }}$ & 76.4 & 76.4 & 76.4 \\
\hline Hydrated Lime & 4.9 & 4.9 & 4.9 \\
\hline Water & 18.7 & 18.7 & 18.7 \\
\hline Mixing Time, $\min$ & 4 & 20.0 & 20.0 \\
\hline \multicolumn{4}{|l|}{ Pelletizer Feed } \\
\hline$\overline{\text { Feed Rate, Ib/min }}$ & ca. 13.4 & ca. 13.4 & ca. 13.4 \\
\hline Water Added, wt $\%$ & 0 & 0 & 0 \\
\hline Pelletization Time, min & ca. 25 & ca. 25 & ca. 25 \\
\hline Curing Temperature, F & $160-170$ & $160-170$ & $160-170$ \\
\hline \multicolumn{4}{|l|}{ Product 'Properties } \\
\hline Crush Strength, Ib & $177 \pm 69$ & $221 \pm 67$ & $204 \pm 56$ \\
\hline $\begin{array}{l}\text { Unit Weight, lb/ft' } \\
\text { As-is }\end{array}$ & 73.4 & 74.1 & 74.0 \\
\hline Dry & 67.4 & 67.2 & 67.6 \\
\hline Particle Size, wt $\%$ pass & $\begin{array}{c}\text { Nos. 8/9 } \\
\text { (Combined) }\end{array}$ & $\begin{array}{c}\text { Nos. 8/9 } \\
\text { (Combined) }\end{array}$ & $\begin{array}{c}\text { Nos. 8/9 } \\
\text { (Combined) }\end{array}$ \\
\hline
\end{tabular}




\section{Determinations of Durability Characteristics of Manufactured Aggregates}

The objective of this task is to determine the durability of manufactured aggregates with distinctly different chemical and physical characteristics. The swelling properties and the effects of natural weathering, freeze/thaw and wet/dry treatments on properties of selected manufactured aggregates were determined for comparison.

As described in the previous section, various manufactured aggregates were selected for the durability study. Aggregates used in the durability study included those made from fixated wet FGD materials, spray dryer ash and FBC ash. All aggregates were made from disk pelletization. The crush strength listed below is the average of ten measurements on ca. $1 / 2 " \times 3 / 8$ " diameter pellets, and is shown as the average \pm one standard deviation.

\section{Natural Weathering Treatment.}

The durability of aggregate was examined by immersing the aggregate in water and exposed to natural weathering over a period of time Changes in aggregate crush strength were determined periodically as a function of weathering time.

Aggregates from Wet FGD Materials with High and Low LOI Fly Ash. Aggregates made in Test Nos. FGD-LM-PS-3 and FGD-LM-OS-4 were used in the natural weathering durability study for comparison.

In Test No. FGD-LM-PS-3, aggregate was produced from fixated lime wet FGD materials with high LOI fly ash (Reliant Energy Elrama Station). The crush strength decreased from $97 \pm 31 \mathrm{lb}$ at 0 day, to $28 \pm 8 \mathrm{lb}$ after 84 days weathering and fractured into pieces after 117 days weathering.

In Test No. FGD-LM-OS-4, aggregate was produced from fixated lime wet FGD materials with low LOI fly ash (AEP Gavin Station). The crush strength changed from $232 \pm 88 \mathrm{lb}$ at 0 days, to $147 \pm 37 \mathrm{lb}$ after 117 days weathering, to $110 \pm 38 \mathrm{lb}$ after 201 days weathering and to $130 \pm 39 \mathrm{lb}$ after 347 days weathering. The aggregate retained over $50 \%$ of crush strength after 347 days weathering, whereas the aggregate made in Test No. FGD-LM-PS-3 lost strength completely after 117 days weathering.

It is evident that aggregate made from fixated wet FGD material with low LOI fly ash is more durable than that made from fixated FGD material with high LOI fly ash.

Aggregates from FBC Ash from Low-Sulfur Lignite and High-Sulfur Coal. Aggregates made in Test Nos. FBC-TS-3 and FBC-FS-1 were used in the natural weathering durability study for comparison.

In Test No. FBC-TS-3, aggregate was produced with FBC ash from low-sulfur lignite (New Mexico Power TNP One Station). The crush strength changed from $329 \pm 78 \mathrm{lb}$ at 0 day, to $296 \pm 105 \mathrm{lb}$ after 21 days weathering, to $328 \pm 108 \mathrm{lb}$ after 44 days weathering 
and to $260 \pm 68 \mathrm{lb}$ after 155 days weathering. The aggregate retained most of strength after 155 days weathering.

In Test No. FBC-FS-1, aggregate was produced with FBC ash from high-sulfur coal and petcoke (JEA Northside Station). The crush strength changed from $240 \pm 80 \mathrm{lb}$ at 0 days, to $204 \pm 87 \mathrm{lb}$ at 7 days weathering, to $228 \pm 79 \mathrm{lb}$ at 14 days weathering, and fractured to pieces after42 days weathering.

These test results show that aggregate made with FBC ash from low-sulfur lignite was more durable than that made with FBC ash from high-sulfur coal.

Aggregates from FBC Ash with Fly Ash Addition. The effect of fly ash addition on durability of aggregates was evaluated with FBC ash from high-sulfur coal and petcoke (JEA Northside Station).

In Test No. FBC-FS-2, aggregate was produced from the FBC ash with $10 \%$ fly ash addition in mix feed (dry basis). The crush strength of aggregate changed from $221 \pm 72$ $\mathrm{lb}$ at 0 day, to $262 \pm 127 \mathrm{lb}$ after 7 days weathering, to $372 \pm 105 \mathrm{lb}$ after 14 weathering days and to $346 \pm 94 \mathrm{lb}$ after 42 days weathering.

In Test No. FBC-FS-3, aggregate was produced from the FBC ash with $30 \%$ fly ash addition in mix feed (dry basis). The crush strength of aggregate changed from $348 \pm 112 \mathrm{lb}$ at 0 day, to $425 \pm 161 \mathrm{lb}$ after 7 days weathering, to $397 \pm 179 \mathrm{lb}$ after 14 days weathering and to $323 \pm 73 \mathrm{lb}$ after 42 days weathering. In contrast to aggregate from FBC ash without fly ash addition, the aggregate with fly ash addition retained or gain strength after 42 days weathering.

Test results indicate that fly ash addition can improve durability of aggregate made with FBC ash from high-sulfur coal and petcoke.

Aggregates from Spray Dryer Ash Made at Different Mixing Times. Aggregates made in Test Nos. SDA-KS-1 and SDA-KS-3 were used in the natural weathering study for comparison.

In Test No. SDA-KS-1, aggregate was produced from SDA with Class $C$ fly ash (Sunflower Power Holcomb Station) with 4 minutes mixing time. The crush strength decreased from $177 \pm 69 \mathrm{lb}$ at 0 day, to $111 \pm 50 \mathrm{lb}$ after 11 days weathering and fractured into pieces after 21 days weathering.

In Test No. SDA-KS-3, aggregate was produced from the same mix formulation except that mix time was increased from 4 minutes to 20 minutes. The crush strength decreased from $204 \pm 56 \mathrm{lb}$ at 0 day, to $194 \pm 60 \mathrm{lb}$ after 21 days weathering, to $141 \pm 47 \mathrm{lb}$ after 44 days weathering and to $73 \pm 29 \mathrm{lb}$ after 155 days weathering. The aggregate retained over $30 \%$ of crush strength after 155 days weathering, whereas the aggregate made in Test No. SDA-KS-1 lost strength completely after 21 days weathering. 
Test results show that the durability of aggregate made from SDA with Class C fly ash can be improved with increasing in mix time.

\section{Freeze and Thaw Treatment}

The durability of aggregate was examined by immersing the aggregate with ca. $1 / 2 " x$ $3 / 8$ " diameter pellets in water in a freeze/thaw chamber and exposing them to 15 continuous freeze and thaw cycles $\left(70^{\circ} \mathrm{F} / 10^{\circ} \mathrm{F}\right)$ over 5 days. Changes in aggregate crush strength and size gradation were determined periodically over the treatment.

Aggregates from Wet FGD Materials. Aggregates made in Test No. FGD-LS-TS-4 and FGD-LS-FS-4 were used in the freeze/thaw durability study for comparison.

In Test No. FGD-LS-TS-1, aggregate was produced from fixated limestone wet FGD material with Class $\mathrm{C}$ fly ash (Reliant Energy Limestone Station). The crush strength decreased from $167 \pm 34 \mathrm{lb}$ after $24 \mathrm{hr}$ soaking in water, to $176 \pm 32 \mathrm{lb}$ after 6 cycles, to $143 \pm 79 \mathrm{lb}$ after 11 cycles, and to $94 \pm 38 \mathrm{lb}$ after 15 cycles of treatment. The treated aggregate retained $100 \%+3 / 8$ " size gradation. No aggregate degradation was observed after freeze and thaw treatment.

In Test No. FGD-LS-FS-4, aggregate was produced from fixated FGD material with Class $\mathrm{F}$ fly ash (Lakeland Mclntosh Station). The crush strength decreased from $130 \pm 54 \mathrm{lb}$ after $24 \mathrm{hr}$ soaking in water, to $83 \pm 19 \mathrm{lb}$ after 6 cycles, to $75 \pm 23 \mathrm{lb}$ after 11 cycles and to $69 \pm 17 \mathrm{lb}$ after 15 cycles of treatment.

The treated aggregate retained $70 \%+3 / 8$ " size gradation. Some aggregate degradation was observed after freeze and thaw treatment. Test results show that aggregate made from fixated FGD material with Class $C$ fly ash is more durable than that made from fixated FGD material with Class $F$ fly ash.

Aggregates from Spray Dryer Ash. Aggregates made in Test Nos. SDA-VS-1 and SDAVS-3 were used in the freeze/thaw durability study for comparison.

In Test No. SDA-VS-1, aggregate was produced from SDA with Class $F$ fly ash (Birchwood Power Station). The crush strength changed from $145 \pm 72 \mathrm{lb}$ after $24 \mathrm{hr}$ soaking, to $119 \pm 43 \mathrm{lb}$ after 6 cycles, and to $164 \pm 41 \mathrm{lb}$ after $15 \mathrm{cycles}$.

In Test No. SDA-VS-3, the aggregate was produced with the same mix formulation except that $6 \%$ of SDA was replaced by cement (dry basis). The crush strength changed from $161 \pm 91 \mathrm{lb}$ after $24 \mathrm{hr}$ soaking, to $168 \pm 75 \mathrm{lb}$ after 6 cycles and to $134 \pm 40$ Ib after 15 cycles treatment.

In both tests, no aggregate degradation was observed after freeze thaw treatment. Test results show that aggregate made from SDA with Class $\mathrm{F}$ fly ash retained strength and size gradation with and without cement addition under freeze and thaw treatment. 


\section{Swelling Tests}

Swelling Tests were conducted by both Geotechnics and the University of Kentucky. The data sheets showing the results of the swelling tests are located in Appendix A and B. Test results and experimental procedures are discussed below.

Geotechnics. Crushed manufactured aggregate with a size gradation of combined Nos. $8 / 9$ was compacted in a California Bearing Resistance (CBR) mold (6" i.d. and 7" height) for evaluation of swell potential upon wetting in accordance with PTM method 130. The molded sample was submerged in water in a controlled oven at $160 \pm 5^{\circ} \mathrm{F}$ for a week and then placed in unsubmerged but saturated conditions in the same heated oven to determine the swell potential for an additional week. The percent of swell was monitored by recording the dial reading periodically. As shown in Table 3-A, aggregates made with SDA from Birchwood power station and FBC ash from Tractebel power Red Hills station swelled $0.087 \%$ and $0.044 \%$ after one week, and $0.022 \%$ and $0.044 \%$ after two weeks, respectively. Both aggregates had less swelling upon wetting than Haydite (a commercial lightweight aggregate), which swelled $0.22 \%$ and $0.17 \%$ under the same testing time and conditions. Aggregate made with FBC ash from AES Guayama station (PR-2-Agg) swelled 1.33\% after one week and the swell remained at $1.33 \%$ after two weeks. With additional treatment, swell of the aggregate (PR-10-Agg) was reduced to $0.14 \%$ after one week and remained at $0.14 \%$ after two weeks testing. In contrast, aggregate made with FBC ash from JEA Northside station continued to swell from $0.63 \%, 0.81 \%, 0.87 \%$ and $0.98 \%$ after one, two, three and four weeks (see Appendix A). The swelling is related to the continuous hydration of quick lime and anhydrite upon wetting in the high sulfur $\mathrm{FBC}$ ash. The ash contained quick lime $(\mathrm{CaO})$ and anhydrite (CaSO4) of $16.5 \%$ and $36.8 \%$, respectively. Both hydration reactions can cause expansion (or swelling).

Table 3-A. Swell Properties of Manufactured Aggregates in the Elevated Temperature Test

\begin{tabular}{|l|c|c|}
\hline Aggregate Type & $\begin{array}{c}\text { 1 week (a) } \\
\text { (\% swell) }\end{array}$ & $\begin{array}{c}\text { 2 weeks (b) } \\
\text { (\% swell) }\end{array}$ \\
\hline SDA (with Class F fly ash) & & \\
Birchwood Agg. (c) & 0.087 & 0.022 \\
\hline FBC Aggregate (from low sulfur coal) & 1.33 & 1.33 \\
PR-2-Agg (d) & 0.14 & 0.14 \\
PR-10-Agg (e) & 0.044 & 0.044 \\
Red Hills Agg (f) & 0.63 & 0.81 \\
\hline FBC Ash (from high sulfur coal/petcoke) & & \\
JEA (g) & 0.22 & 0.17 \\
\hline Commercial Aggregate & 0.02 & 0.02 \\
\hline Hyd-Agg (h) & & \\
\hline
\end{tabular}

(a) Submerged in water at $160 \pm 5^{\circ} \mathrm{F}$ in the first week

(b) Unsubmerged but saturated in water at $160 \pm 5^{\circ} \mathrm{F}$ in the second week 
(c) Aggregate made with SDA from Birchwood power station in Virginia

(d) Aggregate made with FBC ash from AES Guayama station in Puerto Rico

(e) Modified PR-2 aggregate with additional treatment

(f) Aggregate made with FBC ash from Tractebel Power Red Hill station in Mississippi

(g) Aggregate made with FBC ash from JEA Northside station in Florida

(h) Haydite lightweight aggregate

University of Kentucky. The swell tests conducted by the University of Kentucky were similar to those done by Geotechnics, except that the molded samples were submerged in water at ambient temperature. Two tests were conducted with each of two samples using minimum and maximum compaction. In minimum compaction, the aggregate sample was loosed packed in the mold. In maximum compaction, the aggregate sample was compacted in the mold (CBR) by rodding. As shown in Table 3-B, aggregates, made with fixated limestone wet FGD from Lakeland Mclntosh station and SDA from Birchwood station had swell of less than $0.1 \%$. Both aggregates had little swelling upon wetting.

Table 3-B. Swell Properties of Manufactured Aggregates in the Ambient Temperature Tests (a)

\begin{tabular}{|l|c|c|}
\hline Aggregate Type & $\begin{array}{c}\text { Max. } \\
\text { (\% Swell) }\end{array}$ & $\begin{array}{c}\text { Min. } \\
\text { (\% Swell) }\end{array}$ \\
\hline $\begin{array}{l}\text { Limestone Wet FGD (Fixated with Class F fly ash) } \\
\text { Lakeland aggregate }\end{array}$ & 0.044 & 0.022 \\
\hline $\begin{array}{l}\text { SDA (with Class F fly ash) } \\
\text { Birchwood aggregate }\end{array}$ & 0.087 & 0.087 \\
\hline
\end{tabular}

(a) From May 8, 2002 to May 31, 2002 


\section{Determinations of Durability Characteristics of Manufactured Aggregate Products}

The objectives of this task are to determine durability properties of aggregate products including concrete masonry units (CMU), asphalt concrete and portland cement concrete made previously with manufactured aggregates in field demonstration. The aggregate product specimens were prepared and subjected to wet/dry, freeze/thaw (with and without immersion in water) cycle treatments. The aggregate products used included those made with lime wet FGD material (fixated with high and low fly ash), limestone wet FGD material (fixated with Class F fly ash) and spray dryer ash (with Class $\mathrm{F}$ fly ash) aggregates in field demonstration. The weight and dimension changes of the aggregate product specimens as a function of cycle treatment were determined.

\section{Wet/Dry Cycles Treatment.}

The objective is to evaluate the effect of wet/dry cycles treatment on durability of aggregate products. The test specimens were cut and trimmed from concrete masonry units and cement concrete cylinders to the desired dimensions and immersed in water at $70{ }^{\circ} \mathrm{F}$ for $24 \mathrm{hr}$ following by drying at $160^{\circ} \mathrm{F}$ for $24 \mathrm{hr}$ in accordance with procedures in ASTM D-559. Dimensions of the test specimens used are shown in the tables below (0 cycle treatment). The changes in dimensions (length, width and height) and weight were determined after completion of 10,20,30, 40 and 50 wet/dry cycle treatments and air dried for three days. Duplicate tests with specimens of slightly different dimensions were conducted for comparison.

Concrete Masonry Units. CMU test specimens were made with lightweight aggregates from limestone wet FGD materials fixated with Class F fly ash (Lakeland Mclntosh Station in Florida). The CMU were produced in a block production plant in Florida. Test results follow in Table 4-A-1. 
Table 4-A-1. The Effects of Wet/Dry Treatment on Durability of Test Specimens A and B (Limestone Wet FGD with Class F Fly Ash)

\begin{tabular}{|l|c|c|c|c|c|c|}
\hline $\begin{array}{l}\text { Number of Wet/Dry } \\
\text { Cycles Treatment }\end{array}$ & $\mathbf{0}$ & $\mathbf{1 0}$ & $\mathbf{2 0}$ & $\mathbf{3 0}$ & $\mathbf{4 0}$ & $\mathbf{5 0}$ \\
\hline $\begin{array}{l}\text { Specimen A } \\
\text { Dimensions, inch }\end{array}$ & & & & & & \\
$\quad$ Length & 7.648 & 7.647 & 7.650 & 7.652 & 7.655 & 7.654 \\
$\quad$ Width & 2.422 & 2.423 & 2.423 & 2.424 & 2.424 & 2.424 \\
$\quad$ Height & 1.364 & 1.367 & 1.366 & 1.367 & 1.367 & 1.366 \\
Weight, gram & 765.8 & 757.6 & 758.8 & 760.1 & 766.4 & 768.2 \\
\hline Specimen B & & & & & & \\
Dimensions, inch & 7.634 & 7.635 & 7.639 & 7.640 & 7.643 & 7.643 \\
$\quad$ Length & 2.463 & 2.466 & 2.466 & 2.466 & 2.466 & 2.466 \\
$\quad$ Width & 1,300 & 1.294 & 1.294 & 1.294 & 1.294 & 1.294 \\
$\quad$ Height & 780.4 & 770.2 & 771.7 & 772.7 & 779.1 & 781.0 \\
\hline Weight, gram & & & & & \\
\hline
\end{tabular}

CMU test specimens were made with lightweight aggregate from lime wet FGD materials fixated with low and high LOI fly ash (AEP Conesville Station in Ohio). The $\mathrm{CMU}$ were produced in a block production plant in Ohio. Test results follow in Table 4A-2

Table 4-A-2. The Effects of Wet/Dry Treatment on Durability of Test Specimens A and B (Lime Wet FGD with High and Low LOI Fly Ash)

\begin{tabular}{|l|c|c|c|c|c|c|}
\hline $\begin{array}{l}\text { Number of Wet/Dry } \\
\text { Cycles Treatment }\end{array}$ & $\mathbf{0}$ & $\mathbf{1 0}$ & $\mathbf{2 0}$ & $\mathbf{3 0}$ & $\mathbf{4 0}$ & $\mathbf{5 0}$ \\
\hline $\begin{array}{l}\text { Specimen A } \\
\text { Dimensions, inch }\end{array}$ & & & & & & \\
$\quad$ Length & 7.540 & 7.540 & 7.544 & 7.544 & 7.545 & 7.542 \\
$\quad$ Width & 2.514 & 2.514 & 2.514 & 2.513 & 2.514 & 2.514 \\
$\quad$ Height & 1.380 & 1.365 & 1.364 & 1.364 & 1.364 & 1.316 \\
Weight, gram & 679.9 & 669.7 & 670.6 & 670.5 & 674.9 & 676.0 \\
\hline $\begin{array}{l}\text { Specimen B } \\
\text { Dimensions, inch }\end{array}$ & & & & & \\
$\quad$ Length & 7.581 & 7.581 & 7.585 & 7.585 & 7.587 & 7.585 \\
$\quad$ Width & 2.492 & 2.482 & 2.484 & 2.484 & 2.484 & 2.484 \\
$\quad$ Height & 1.355 & 1.347 & 1.341 & 1.340 & 1.341 & 1.341 \\
$\quad$ Weight, gram & 742.5 & 731.7 & 733.5 & 734.1 & 740.7 & 741.9 \\
\hline
\end{tabular}

CMU test specimens were made with lightweight aggregates from spray dryer ash with Class $\mathrm{F}$ fly ash (Birchwood Power Station in Virginia). The CMU were produced in a block production plant in Maryland. Test results follow in Table 4-A-3. 
Table 4-A-3. The Effects of Wet/Dry Treatment on Durability of Test Specimens A and B (Spray Dryer Ash with Class F fly ash)

\begin{tabular}{|l|c|c|c|c|c|c|}
\hline $\begin{array}{l}\text { Number of Wet/Dry } \\
\text { Cycles Treatment }\end{array}$ & $\mathbf{0}$ & $\mathbf{1 0}$ & $\mathbf{2 0}$ & $\mathbf{3 0}$ & $\mathbf{4 0}$ & $\mathbf{5 0}$ \\
\hline $\begin{array}{l}\text { Specimen A } \\
\text { Dimension, inch }\end{array}$ & & & & & & \\
$\quad$ Length & 7.618 & 7.618 & 7.620 & 7.621 & 7.622 & 7.620 \\
Width & 2.525 & 2.522 & 2.523 & 2.523 & 2.523 & 2.523 \\
$\quad$ Height & 1.312 & 1.311 & 1.309 & 1.309 & 1.308 & 1.308 \\
Weight, gram & 712.8 & 702.2 & 703.9 & 704.5 & 708.7 & 711.0 \\
\hline Specimen B & & & & & & \\
Dimension, inch & & & & & & \\
$\quad$ Length & 7.594 & 7.593 & 7.595 & 7.595 & 7.598 & 7.564 \\
Width & 2.488 & 2.488 & 2.486 & 2.486 & 2.487 & 2.488 \\
$\quad$ Height & 1.462 & 1.457 & 1.457 & 1.456 & 1.456 & 1.456 \\
Weight, gram & 684.1 & 672.2 & 673.2 & 673.8 & 678.1 & 679.9 \\
\hline
\end{tabular}

Cement Concrete. The cement concrete test specimens used in the wet/dry study were made from two cement concrete cylinders with different mix formulation (mix designs 1 and 2). The cement concrete cylinders were prepared with lightweight aggregate from lime wet FGD materials fixated with low and high LOI fly ash (AEP Conesville Station in Ohio) and they were used in qualification tests for use as lightweight structural concrete $^{1,2}$. Test results follow in Tables 4-B-1 and 4-B-2

Table 4-B-1. The Effects of Wet/Dry Treatment on Durability of Test Specimens and B FROM MIX DESIGN 1 (Lime Wet FGD with High and Low LOI Fly Ash)

\begin{tabular}{|l|c|c|c|c|c|c|}
\hline $\begin{array}{l}\text { Number of wet/dry } \\
\text { Cycles Treatment }\end{array}$ & $\mathbf{0}$ & $\mathbf{1 0}$ & $\mathbf{2 0}$ & $\mathbf{3 0}$ & $\mathbf{4 0}$ & $\mathbf{5 0}$ \\
\hline $\begin{array}{l}\text { Specimen A } \\
\text { Dimension, inch }\end{array}$ & & & & & & \\
$\quad$ Length & 3.000 & 2.999 & 2.999 & 2.999 & 2.999 & 2.999 \\
Width & 0.969 & 0.969 & 0.970 & 0.970 & 0.970 & 0.971 \\
$\quad$ Height & 3.046 & 3.046 & 3.047 & 3.047 & 3.047 & 3.048 \\
Weight, gram & 218.2 & 217.4 & 218.3 & 218.5 & 220.9 & 221.6 \\
\hline Specimen B & & & & & & \\
Dimension, inch & & & & & & \\
$\quad$ Length & 2.935 & 2.935 & 2.935 & 2.936 & 2.936 & 2.937 \\
$\quad$ Width & 0.957 & 0.957 & 0.957 & 0.958 & 0.958 & 0.958 \\
$\quad$ Height & 3.033 & 3.034 & 3.030 & 3.029 & 3.030 & 3.032 \\
Weight,gram & 213.0 & 212.0 & 212.8 & 213.1 & 215.3 & 215.9 \\
\hline
\end{tabular}


Table 4-B-2. The Effects of Wet/Dry Treatment on Durability of Test Specimens A and B FROM MIX DESIGN 2 (Lime Wet FGD with High and Low LOI Fly Ash)

\begin{tabular}{|l|c|c|c|c|c|c|}
\hline $\begin{array}{l}\text { Number of Wet/dry } \\
\text { Cycles Treatment }\end{array}$ & $\mathbf{0}$ & $\mathbf{1 0}$ & $\mathbf{2 0}$ & $\mathbf{3 0}$ & $\mathbf{4 0}$ & $\mathbf{5 0}$ \\
\hline $\begin{array}{l}\text { Specimens A } \\
\text { Dimension, inch }\end{array}$ & & & & & & \\
$\quad$ Length & 2.922 & 2.923 & 2.925 & 2.926 & 2.927 & 2.928 \\
$\quad$ Width & 1.192 & 1.195 & 1.194 & 1.194 & 1.194 & 1.194 \\
$\quad$ Height & 2.825 & 2.829 & 2.823 & 2.824 & 2.825 & 2.825 \\
Weight, gram & 228.1 & 226.1 & 227.9 & 229.5 & 233.2 & 234.8 \\
\hline Specimen B & & & & & & \\
Dimension, inch & & & & & & \\
$\quad$ Length & 2.940 & 2.945 & 2.945 & 2.946 & 2.947 & 2.948 \\
$\quad$ Width & 1.074 & 1.076 & 1.078 & 1.077 & 1.078 & 1.078 \\
$\quad$ Height & 2.858 & 2.863 & 2.865 & 2.865 & 2.859 & 2.861 \\
Weight, gram & 209.8 & 206.9 & 208.6 & 209.8 & 213.1 & 214.5 \\
\hline
\end{tabular}

From above, little dimension (height, width and length) and weight changes were observed with duplicate test specimens during wet/dry treatments. CMU and cement concrete test specimens made with manufactured lightweight aggregates all had high wet/dry resistance after 50 cycles of treatments. The test specimens were immersed in water during the wet cycle treatment.

\section{Freeze/Thaw Treatment without Immersion in Water.}

The objective is to evaluate the effect of freeze/thaw cycles on durability of aggregate products, which were in saturated-surface-dry conditions (SSD) conditions, but not immersed in water. The test specimens were cut and trimmed from concrete masonry units, cement concrete cylinders and asphalt concrete to the desired dimensions and soaked in water for saturation for 48 hours. The saturated specimens were then sealed in plastic bags and frozen at $-6{ }^{\circ} \mathrm{F}$ for $24 \mathrm{hr}$ following by thawing at $70^{\circ} \mathrm{F}$ for $24 \mathrm{hr}$ in accordance with procedures in ASTM D-560. Dimensions of the test specimens are shown in the table below ( 0 cycle treatment). The changes in dimensions (length, width and height) and weight were determined after completion of 20,30, 40 and 50 freeze/thaw treatments. Duplicate tests with specimens of slightly different dimensions were conducted for comparison.

Concrete Masonry Units. CMU test specimens were made with lightweight aggregates from limestone wet FGD materials fixated with Class F fly ash (Lakeland Mclntosh Station in Florida). The CMU were produced in the block production plant in Florida, as those used in the wet/dry cycles treatment tests. Test results follow in Table 4-C-1. 
Table 4-C-1. The Effects of Wet/Dry Treatment on Durability of Test Specimens A and B (Limestone Wet FGD with Class F Fly Ash)

\begin{tabular}{|l|c|c|c|c|c|}
\hline $\begin{array}{l}\text { Number of Freeze/Thaw } \\
\text { Cycles Treatment }\end{array}$ & $\mathbf{0}$ & $\mathbf{2 0}$ & $\mathbf{3 0}$ & $\mathbf{4 0}$ & $\mathbf{5 0}$ \\
\hline Specimen A & & & & & \\
Dimension, inch & 7.549 & 7.553 & 7.556 & 7.566 & 7.557 \\
Length & 2.533 & 2.533 & 2.531 & 2.535 & 2.534 \\
Width & 1.525 & 1.525 & 1.522 & 1.525 & 1.525 \\
Height & 864.5 & 863.7 & 863.0 & 862.1 & 861.0 \\
Weight, gram & & & & & \\
\hline Specimen B & & & & \\
Dimension, inch & 7.534 & 7.540 & 7.546 & 7.546 & 7.530 \\
Length & 2.250 & 2.251 & 2.250 & 2.252 & 2.253 \\
Width & 1.163 & 1.164 & 1.160 & 1.160 & 1.161 \\
Height & 708.5 & 707.7 & 707.0 & 706.5 & 705.2 \\
\hline Weight, gram & & & & & \\
\hline
\end{tabular}

CMU test specimens were made with lightweight aggregate from lime wet FGD materials fixated with low and high LOI (AEP Conesville Station in Ohio). The CMU were produced in the block production plant, as those used in the wet/dry cycles treatment tests. Test results follow in Table 4-C-2

Table 4-C-2. The Effects of Wet/Dry Treatment on Durability of Test Specimens A and B (Lime Wet FGD with High and Low LOI Fly Ash)

\begin{tabular}{|l|l|l|l|l|l|}
\hline $\begin{array}{l}\text { Number of Freeze/Thaw } \\
\text { Cycles Treatment }\end{array}$ & $\mathbf{0}$ & $\mathbf{2 0}$ & $\mathbf{3 0}$ & $\mathbf{4 0}$ & $\mathbf{5 0}$ \\
\hline $\begin{array}{l}\text { Specimen A } \\
\text { Dimension, inch }\end{array}$ & & & & & \\
\hline Length & 7.566 & 7.611 & 7.618 & 7.618 & 7.619 \\
Width & 2.526 & 2.537 & 2.543 & 2.543 & 2.543 \\
$\begin{array}{l}\text { Height } \\
\text { Weight, gram }\end{array}$ & 1.304 & $1.320(\mathrm{a})$ & $1.315(\mathrm{a})$ & $1.316(\mathrm{a})$ & $1.316(\mathrm{a})$ \\
\hline Specimen B & 783.0 & 778.4 & 775.1 & 772.9 & 770.9 \\
Dimension, inch & & & & & \\
$\quad$ Length & 7,589 & 7.599 & 7.619 & 7.602 & 7.605 \\
$\quad$ Width & 2.595 & 2.602 & 2.604 & 2.605 & 2.605 \\
$\quad$ Height & 1.321 & 1.322 & 1.323 & 1.325 & 1.326 \\
Weight, gram & 844.4 & 842.2 & 841.8 & 840.9 & 839.6 \\
\hline
\end{tabular}

(a) Slightly crumbled

CMU test specimens were made with lightweight aggregate from spray dryer ash with Class F fly ash (Birchwood Power Station in Virginia). The CMU were produced in the block plant in Maryland as those used in the wet/dry cycles treatment test. Test results follow in Table 4-C-3. 
Table 4-C-3. The Effects of Wet/Dry Treatment on Durability of Test Specimens A and B (Spray Dryer Ash with Class F Fly Ash)

\begin{tabular}{|l|l|l|l|l|l|}
\hline $\begin{array}{l}\text { Number of Freeze/Thaw } \\
\text { Cycles Treatment }\end{array}$ & $\mathbf{0}$ & $\mathbf{2 0}$ & $\mathbf{3 0}$ & $\mathbf{4 0}$ & $\mathbf{5 0}$ \\
\hline $\begin{array}{l}\text { Specimen A } \\
\text { Dimension, inch }\end{array}$ & & & & & \\
\hline Length & 7.635 & 7.645 & 7.656 & 7.660 & 7.669 \\
$\quad$ Height & 2.672 & 2.670 & 2.677 & 2.678 & 2.683 \\
Width & 1.278 & 1.277 & 1.284 & 1.287 & 1.293 \\
Weight, gram & 814.5 & 813.7 & 813.2 & 812.8 & 811.5 \\
\hline Specimen B & & & & & \\
Dimension, inch & & & & & \\
Length & 7.612 & 7.634 & 7.642 & 7.649 & 7.652 \\
$\quad$ Height & 2.529 & 2.541 & 2.546 & 2.551 & 2.551 \\
Width & 1.297 & 1.303 & 1.303 & 1.306 & 1.306 \\
Weight, gram & 794.4 & 793.6 & 792.9 & 792.4 & 790.8 \\
\hline
\end{tabular}

Cement Concrete. The cement concrete test specimens used in the freeze/thaw study were made from two cement concrete cylinders with different mix formulations (mix design 1 and 2), just as in the wet/dry treatment study. Test results follow in Tables 4D-1 and 4-D-2

Table 4-D-1. The Effects of Freeze/Thaw Treatment on Durability of Test Specimens A and B from Mix Design 1 (Lime Wet FGD with High and Low LOI Fly Ash)

\begin{tabular}{|l|l|l|l|l|l|}
\hline $\begin{array}{l}\text { Number of freeze/thaw } \\
\text { Cycles Treatment }\end{array}$ & $\mathbf{0}$ & $\mathbf{2 0}$ & $\mathbf{3 0}$ & $\mathbf{4 0}$ & $\mathbf{5 0}$ \\
\hline $\begin{array}{l}\text { Specimen A } \\
\text { Dimension, inch }\end{array}$ & & & & & \\
\hline $\begin{array}{c}\text { Length } \\
\text { Width }\end{array}$ & 2.896 & 2.894 & 2.894 & 2.898 & 2.899 \\
$\begin{array}{c}\text { Height } \\
\text { Weight, gram }\end{array}$ & 0.951 & 0.950 & 0.950 & 0.952 & 0.951 \\
\hline Specimen B & 3.001 & 3.001 & 2.998 & 3.002 & 3.005 \\
Dimension, inch & 222.5 & 221.5 & 220.5 & 219.0 & 216.8 \\
\hline Length & & & & & \\
Width & 3.005 & 3.011 & 3.011 & 3.009 & 3.012 \\
Height & 0.960 & 0.959 & 0.959 & 0.960 & 0.961 \\
Weight, gram & 3.039 & 3.046 & 3.041 & 3.043 & 3.045 \\
\hline
\end{tabular}


Table 4-D-2. The Effects of Freeze/Thaw Treatment on Durability of Test Specimens A and B from Mix Design 2 (Lime Wet FGD with High and Low LOI Fly Ash)

\begin{tabular}{|l|c|c|c|c|c|}
\hline $\begin{array}{l}\text { Number of freeze/thaw } \\
\text { Cycles Treatment }\end{array}$ & $\mathbf{0}$ & $\mathbf{2 0}$ & $\mathbf{3 0}$ & $\mathbf{4 0}$ & $\mathbf{5 0}$ \\
\hline $\begin{array}{c}\text { Specimen A } \\
\text { Dimension, inch }\end{array}$ & & & & & \\
\hline $\begin{array}{l}\text { Length } \\
\text { Width }\end{array}$ & 2.919 & 2.910 & 2.920 & 2.921 & 2.921 \\
$\begin{array}{c}\text { Height } \\
\text { Weight, gram }\end{array}$ & 1.127 & 1.219 & 1.129 & 1.130 & 1.130 \\
\hline Specimen B & 2.786 & 2.784 & 2.791 & 2.788 & 2.786 \\
$\begin{array}{c}\text { Dimension, inch } \\
\text { Length }\end{array}$ & 230.4 & 229.3 & 228.4 & 227.1 & 225.4 \\
$\quad$ Width & 2.919 & 2.919 & 2.924 & 2.922 & 2.920 \\
$\quad$ Height & 1.220 & 1.222 & 1.222 & 1.222 & 1.223 \\
Weight, gram & 2.831 & 2.831 & 2.828 & 2.834 & 2.838 \\
\hline
\end{tabular}

Asphalt Concrete. The asphalt concrete test specimens used in the freeze/thaw study were made from three drill core samples from the asphalt pavement demonstrations with manufactured road aggregates in Warren, Ohio, South Park, Pennsylvania and Nokomis Florida (See Summary of Related works). Test results follow in Table 4-E-1, $4-\mathrm{E}-2$ and $4-\mathrm{E}-3$.

Table 4-E-1 The Effects of Freeze/Thaw Treatment on Durability of Test Specimens A and B of Drill Core Samples from Asphalt Pavement in Warren, Ohio

\begin{tabular}{|l|c|c|c|c|c|}
\hline $\begin{array}{l}\text { Number of Freeze/Thaw } \\
\text { Cycles Treatment }\end{array}$ & $\mathbf{0}$ & $\mathbf{2 0}$ & $\mathbf{3 0}$ & $\mathbf{4 0}$ & $\mathbf{5 0}$ \\
\hline Specimen A & & & & & \\
Dimension, inch & & & & & \\
\hline Length & 2.916 & 2.915 & 2.915 & 2.916 & 2.912 \\
Width & 0.911 & 0.911 & 0.911 & 0.911 & 0.916 \\
Height & 2.966 & 2.961 & 2.962 & 2.961 & 2.959 \\
Weight & 246.7 & 246.6 & 246.5 & 246.5 & 246.5 \\
\hline Specimen B & & & & & \\
Dimension, inch & & & & & \\
Length & 2.893 & 2.890 & 2.891 & 2.896 & 2.890 \\
Width & 0.908 & 0.908 & 0.909 & 0.910 & 0.909 \\
$\quad$ Height & 2.964 & 2.963 & 2.963 & 2.962 & 2.962 \\
Weight, gram & 236.6 & 236.5 & 236.5 & 236.5 & 236.5 \\
\hline
\end{tabular}


Table 4-E-2 The Effects of Freeze/Thaw Treatment on Durability of Test Specimens A and B of Drill Core samples from Asphalt Pavement in South Park, Pennsylvania.

\begin{tabular}{|l|c|c|c|c|c|}
\hline $\begin{array}{l}\text { Number of Freeze/Thaw } \\
\text { Cycles Treatment }\end{array}$ & $\mathbf{0}$ & $\mathbf{2 0}$ & $\mathbf{3 0}$ & $\mathbf{4 0}$ & $\mathbf{5 0}$ \\
\hline Specimen A & & & & & \\
Dimension, inch & 2.836 & 2.838 & 2.838 & 2.837 & 2.836 \\
$\quad$ Length & 0.897 & 0.896 & 0.896 & 0.897 & 0.897 \\
Width & 2.948 & 2.981 & 2.945 & 2.951 & 2.949 \\
$\quad$ Height & 232.8 & 232.7 & 232.7 & 232.7 & 232.6 \\
\hline Weight, gram & & & & & \\
\hline Specimen B & & & & \\
Dimension, inch & 2.866 & 2.865 & 2.865 & 2.866 & 2.869 \\
Length & 0.902 & 0.902 & 0.902 & 0.904 & 0.904 \\
Width & 2.911 & 2.910 & 2.912 & 2.916 & 2.916 \\
Height & 236.0 & 235.9 & 235.9 & 235.9 & 235.8 \\
\hline Weight, gram & & & & & \\
\hline
\end{tabular}

Table 4-E-3 The Effects of Freeze/Thaw Treatment on Durability of Test Specimens A and B of Drill Core Samples from Asphalt Pavement in Nokomis, Florida

\begin{tabular}{|l|c|c|c|c|c|}
\hline $\begin{array}{l}\text { Number of Freeze/Thaw } \\
\text { Cycles Treatment }\end{array}$ & $\mathbf{0}$ & $\mathbf{2 0}$ & $\mathbf{3 0}$ & $\mathbf{4 0}$ & $\mathbf{5 0}$ \\
\hline Specimen A & & & & & \\
$\quad$ Dimension, inch & 2.868 & 2.867 & 2.867 & 2.870 & 2.869 \\
$\quad$ Length & 1.122 & 1.125 & 1.122 & 1.125 & 1.124 \\
Width & 2.819 & 2.616 & 2.819 & 2.820 & 2.819 \\
$\quad$ Height & 251.6 & 250.9 & 250.8 & 250.8 & 250.7 \\
Weight, gram & & & & & \\
\hline Specimen B & 2.818 & 2.818 & 2.817 & 2.820 & 2.818 \\
Dimension, inch & 1.081 & 1.083 & 1.083 & 1.084 & 1.083 \\
Length & 2.915 & 2.915 & 2.915 & 2.918 & 2.019 \\
$\quad$ Width & 241.6 & 241.0 & 241.0 & 241.0 & 240.9 \\
$\quad$ Weight & & & & & \\
\hline
\end{tabular}

From above, CMU and cement concrete test specimens made with manufactured aggregates from either limestone wet FGD materials or spray dryer ash had high freeze/thaw resistance after 50 cycles of treatment. Little dimension and weight changes were observed during treatments. In comparison, one test specimen made with manufactured aggregates from lime wet FGD materials was slightly crumbled on the surface and lost $1.5 \%$ weight after treatment, indicating less freeze/thaw resistance. Both cement and asphalt concrete test specimens made with lime wet FGD materials had high freeze/thaw resistance. The test specimens were in saturated-surface-dry 
conditions, but not immersed in water. This simulated the natural conditions of freeze/thaw cycles in most applications of CMU and cement concrete in construction.

\section{Freeze/Thaw Treatment with Immersion in Water.}

The objective is to evaluate the effect of continuous freeze/thaw cycles treatment on the durability of aggregate products, while immersed in water. The test specimens were cut and trimmed from concrete masonry units and asphalt concrete cylinders to the desired dimensions and immersed in water for 24 hours in a freeze/thaw chamber before testing. The immersed test specimens were then subjected to continuous freeze/thaw cycles treatment $\left(-4^{\circ} \mathrm{F} / 60^{\circ} \mathrm{F}\right)$ in accordance with procedures in ASTM D-666. The analyst recorded the number of the freeze/thaw cycles for test specimens to lose structural integrity.

As shown in Table 4-F-1, CMU test specimens made with manufactured lightweight aggregates from either limestone wet FGD materials or spray dryer ash had medium freeze/thaw resistance after 20 cycles of treatment. Test specimens made with aggregate from lime wet FGD material were degraded after 20 cycles of treatment.

Table 4-F-1 The Effect of Freeze/Thaw Treatment on Durability of CMU Test Specimens

\begin{tabular}{|l|c|c|c|c|}
\hline \multicolumn{1}{|c|}{$\begin{array}{c}\text { Number of Freeze/Thaw } \\
\text { Cycles Treatment }\end{array}$} & $\mathbf{6}$ & $\mathbf{1 0}$ & $\mathbf{1 5}$ & $\mathbf{2 0}$ \\
\hline $\begin{array}{l}\text { Limestone Wet FGD Aggregate } \\
\text { (Fixated with Class F fly ash) }\end{array}$ & good & good & good & $\begin{array}{c}\text { slightly } \\
\text { spalling }\end{array}$ \\
\hline $\begin{array}{l}\text { Lime Wet FGD Aggregate } \\
\text { (Fixated with low and high LOl fly ash }\end{array}$ & good & $\begin{array}{c}\text { slightly } \\
\text { spalling }\end{array}$ & $\begin{array}{c}\text { spalling } \\
\text { spalling } \\
\text { and cracking }\end{array}$ \\
\hline $\begin{array}{l}\text { Spray Dryer Ash Aggregate } \\
\text { (With Class F fly ash) }\end{array}$ & good & good & $\begin{array}{c}\text { slightly } \\
\text { spalling }\end{array}$ & slightly spalling \\
\hline
\end{tabular}

In comparison, test specimens of asphalt concrete made with manufactured aggregate from lime wet FGD materials maintained structural integrity after 200 freeze/thaw cycle treatment indicating high freeze/thaw resistance.

Test results show that immersion in water had a profound effect on the freeze/thaw resistance of $\mathrm{CMU}$ made with manufactured lightweight aggregate. Mix designs for aggregate and aggregate products production need to be modified, if simultaneous freeze/thaw at the extreme low temperature (i.e., $-4^{\circ} \mathrm{F}$ ) and water immersion cannot be avoided in the application.

\section{Drying Shrinkage Evaluation}

The objective is to evaluate shrinkage or expansion properties of combined manufactured aggregate and cement during wet and dry treatments. Excessive interaction of manufactured aggregate with cement could cause drying shrinkage problems in aggregate products. Aggregate in as-is and saturated-surface-dry (SSD) conditions were used in the evaluation. The mixed aggregate and cement were blended 
with adequate amount of water to produce a mix with a slump of 2 " to 3 " and then placed in a steel mold (2" × 2" × $111 / 4 "$ ") to form a mortar bar for curing, in accordance with procedures in ASTM C157 and C331. The mortar bars were cured in moist conditions (over $95 \%$ humidity or immersion in water) and subsequently subjected to drying treatments. Length changes of the mortar bars were measured after drying at 7 , 28 and 100 days. The specification for drying shrinkage for lightweight aggregate is $0.1 \%$ length change (maximum) in accordance with ASTM C331.

SDA Aggregate. Shrinkage properties of manufactured aggregate, made with SDA from Birchwood power station, were determined in as-is and SSD conditions after drying at 7, 28 and 100 days. As shown in Table 4-G-1, drying shrinkage of SDA aggregate in SSD conditions did not meet the ASTM specification (0.1\%, max.). With additive addition, shrinkage of the aggregate was reduced and met the specification.

Table 4-G-1 Drying Shrinkage of SDA Aggregate

\begin{tabular}{|l|c|c|c|}
\hline \multirow{2}{*}{} & \multicolumn{3}{|c|}{ Length Change, \% (a) } \\
\cline { 2 - 4 } & 7 days & 28 days & 100 days \\
\hline SDA Aggregate (as-is) (b) & & & \\
Bar \#1 & 0.003 & 0.007 & 0.026 \\
Bar \#2 & 0.006 & 0.014 & 0.026 \\
\hline SDA Aggregate (SSD) (b) & & & \\
Bar \#1 & 0.001 & 0.019 & 0.132 \\
Bar \#2 & 0.001 & 0.019 & 0.129 \\
\hline SDA Aggregate (as-is) (c) & & & \\
Bar \#1 & 0.002 & 0.008 & 0.029 \\
Bar \#2 & 0,001 & 0.009 & 0.028 \\
\hline SDA Aggregate (SSD) (c) & & & \\
Bar \#1 & 0.001 & 0.017 & 0.035 \\
Bar \#2 & 0.001 & 0.016 & 0.034 \\
\hline
\end{tabular}

(a) Shrinkage

(b) Without additive addition in aggregate production

(c) With additive addition in aggregate production 
FBC Aggregate Shrinkage properties of manufactured aggregate, made with FBC from AES Guayama station were determined in as-is and SSD conditions after drying for 7 , 28 and 100 days, As shown in Table 4-H-1, the mortar bars were expanding instead of shrinking during treatment. Further study is needed to identify the cause of expansion.

Table 4-H-1 Drying Shrinkage of FBC Aggregate

\begin{tabular}{|l|c|c|c|}
\hline \multirow{2}{*}{} & \multicolumn{3}{|c|}{ Length Change, \% (a) } \\
\cline { 2 - 4 } & $\mathbf{7}$ days & 28 days & 100 days \\
\hline FBC Aggregate (as-is) & & & \\
Bar \#1 & 0.114 & 0.342 & 0.143 \\
Bar \#2 & 0.121 & 0.285 & 0.113 \\
\hline FBC Aggregate (SSD) & & & \\
Bar \#1 & 0.060 & 0.104 & 0.089 \\
Bar \#2 & 0.075 & 0.117 & 0.085 \\
\hline
\end{tabular}

(a) Expansion 


\section{CONCLUSION}

Conclusions appear in the Executive Summary section. 


\section{REFERENCES}

1 McCoy, D. C., Wu, M. M., "Demonstration of the Production of Manufactured Aggregates from AEP Gavin and Conesville Station FGD Sludges," Final Report for OCDO Grant Agreement No. CDO/D-98-17, May 31, 2003

2 Wu, M. M., McCoy, D. C., "Aggregate Production from Lime Wet FGD Sludge," Final Report for OCDO Grant Agreement No. CDO/D-95-2, February 6, 2004

3 Wu, M. M., McCoy, D. C., Scandrol, R. O., Fenger, M. L., Withum, J. A., Statnick, R. M., "Production of Construction Aggregates from Flue Gas Desulfurization Sludge", DOE Final Report, Cooperative Agreement No. DE-FC26-98FT40027, May 2000. 
Appendix A. Swelling Tests - Geotechnics Laboratory 
DCN: DS-S33

DATE: $\quad 11 / 14 / 96$

REVISION: 1
Appendix A

ONE DIMENSIONAL SWELL

PTM 130 $\begin{array}{ll}\text { Boring No. } & \text { NA } \\ \text { Depth } & \text { NA } \\ \text { Sample No. } & \text { Birchwood Agg. } \\ \text { Visual Description } & \text { Gray Aggregate }\end{array}$

Standard

S. Height 4.58

$1 \operatorname{div}($ in) $\quad 0.001$

Surcharge (Ibs)

Wt. of Mold \& WS (gm)

Wt. of Mold (gm)

Wt. of WS

Mold Volume (cc)

Wet Density $(\mathrm{gm} / \mathrm{cc})$

Wet Density (pcf)

Tare Number

Wt. of Tare \& WS (gm)

na

\begin{tabular}{cc} 
Initial & Fina \\
\hline 9518 & 991 \\
7130 & 7130 \\
2388 & 278 \\
2124 & 212 \\
1.12 & 1.3 \\
70.2 & 81.8
\end{tabular}

1711

563

221.35

293.7

Wt. of Tare \& DS $(\mathrm{gm})$

201.87

237.2

Wt. of Tare $(\mathrm{gm})$

82.72

Wt. of Water (gm)

83.54

56.5

Wt. of DS (gm)

118.33

154.48

Water Content $(\%)$

16.5

36.6

Dry Density (pcf)

60.2

59.9

(*) Sample was removed from the submerged condition after the 166 hour reading.

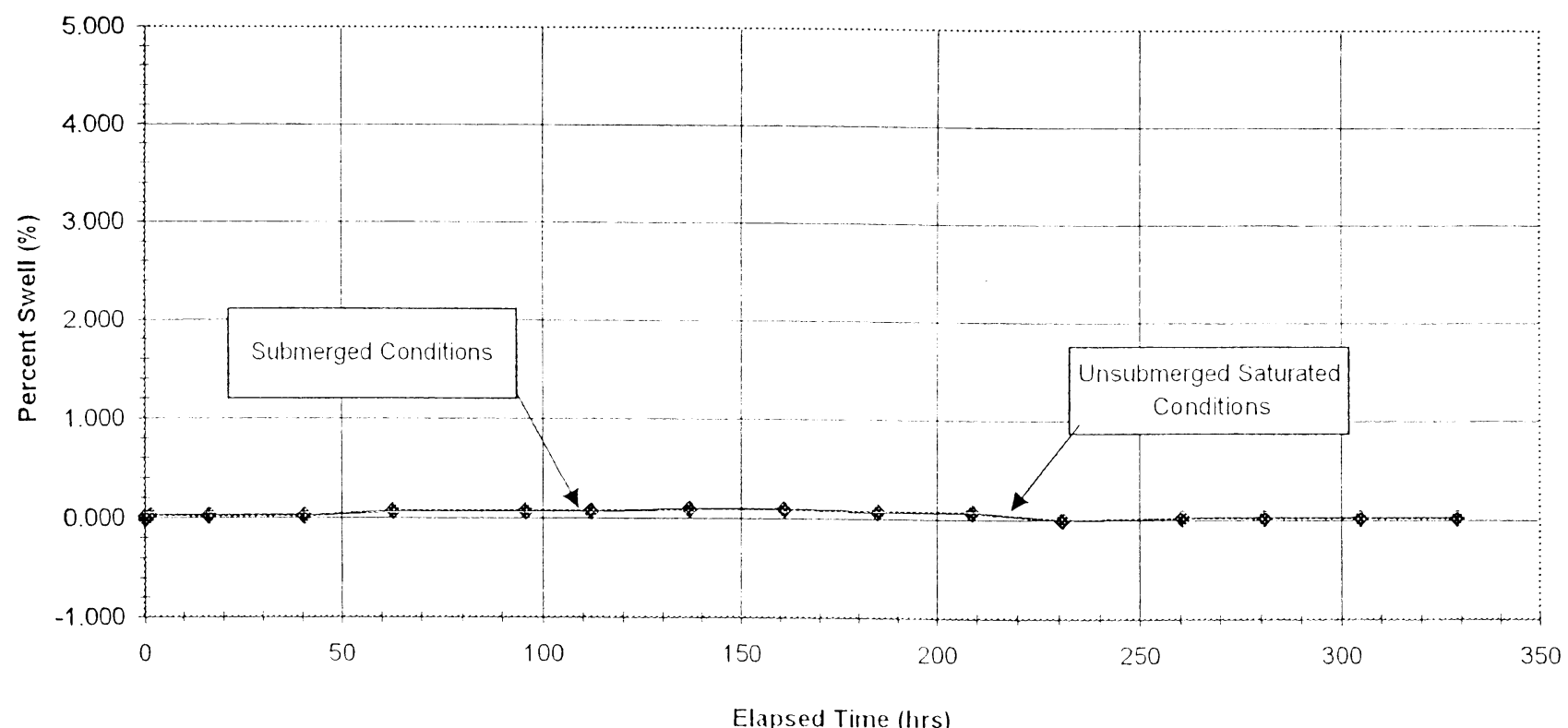

Tested By IP/DA Date 10/23/02 Checked By G1) Date /1->-O2

page 1 of 1 
DCN: $\quad$ DS-S33

Appendix A

DATE: $\quad 11 / 14 / 96$

REVISION: 1

\section{ONE DIMENSIONAL SWELL PTM 130}

$\begin{array}{ll}\text { Client } & \text { Universal Aggregates } \\ \text { Client Reference } & \text { Swell Testing } \\ \text { Project No. } & \text { 2002-286-01 } \\ \text { Lab ID } & 2002-286-01-02\end{array}$

$\begin{array}{ll}\text { Boring No. } & \text { NA } \\ \text { Depth } & \text { NA } \\ \text { Sample No. } & \text { Red Hills Agg. } \\ \text { Visual Description } & \text { Gray Aggregate }\end{array}$

\begin{tabular}{ccc}
$\begin{array}{c}\text { Dial } \\
\text { Reading } \\
\text { (div) }\end{array}$ & $\begin{array}{c}\text { Percent } \\
\text { Swell } \\
(\%)\end{array}$ & $\begin{array}{c}\text { Elapsed } \\
\text { Time } \\
\text { (hrs) }\end{array}$ \\
\hline 615 & 0.000 & 0 \\
617 & 0.044 & 0.5 \\
614 & -0.022 & 1.5 \\
616 & 0.022 & 16.5 \\
612 & -0.066 & 40.5 \\
617 & 0.044 & 63.0 \\
617 & 0.044 & 96.0 \\
617 & 0.044 & 112.0 \\
617 & 0.044 & 138.0 \\
617 & 0.044 & 161.0 \\
617 & 0.044 & 185.0 \\
617 & 0.044 & 208.0 \\
616 & 0.022 & 231.0 \\
616 & 0.022 & 260.5 \\
616 & 0.022 & 280.0 \\
617 & 0.044 & 305.0 \\
617 & 0.044 & 329.0
\end{tabular}

$\begin{array}{lc}\text { Test Type } & \text { Standard } \\ \text { Surcharge (Ibs) } & \text { na }\end{array}$

Wt. of Mold \& WS (gm) Wt. of Mold (gm) Wt. of WS

Mold Volume (cc) Wet Density $(\mathrm{gm} / \mathrm{cc})$ Wet Density (pcf)

Tare Number Wt. of Tare \& WS $(\mathrm{gm})$ Wt. of Tare \& DS (gm) Wt. of Tare $(\mathrm{gm})$ Wt. of Water (gm) Wt. of DS (gm)

Water Content (\%) Dry Density (pcf)

\section{S. Height 4.58 $1 \mathrm{div}$ (in) $\quad 0.001$}

\begin{tabular}{cc} 
Initial & Final \\
\hline 9428 & 10139 \\
7120 & 7120 \\
2308 & 3019 \\
2124 & 2124 \\
1.09 & 1.42 \\
67.8 & 88.7 \\
& \\
592 & $1719 \mathrm{~A}$ \\
182.98 & 374 \\
173.48 & 282.91 \\
81.64 & 84.8 \\
9.5 & 91.09 \\
91.84 & 198.11
\end{tabular}

10.3

46.0

61.4

(*) Sample was removed from the submerged condition after the 166 hour reading.

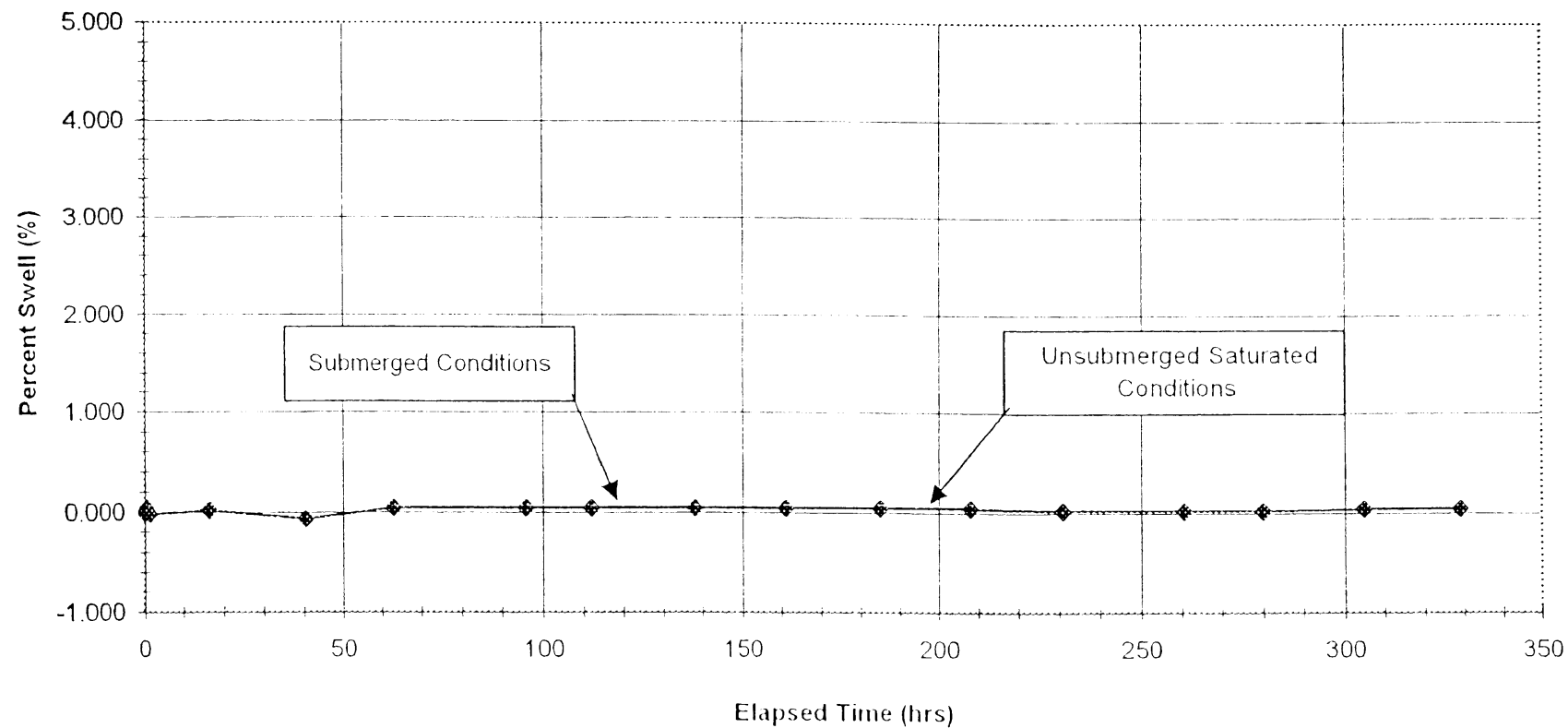

Tested By JP/DA Date 10/23/02 Checked By C, Date $11 / 7102$ 
Appendix A

$\begin{array}{ll}\text { DCN: } & \text { DS-S33 } \\ \text { DATE: } & 11 / 14 / 96\end{array}$

REVISION: 1

ONE DIMENSIONAL SWELL

PTM 130

$\begin{array}{ll}\text { Client } & \text { Universal Aggregates } \\ \text { Client Reference } & \text { Svell Testing } \\ \text { Project No. } & 2002-286-04 \\ \text { Lab ID } & 2002-286-04-01\end{array}$

\begin{tabular}{ccc}
$\begin{array}{c}\text { Dial } \\
\text { Reading } \\
\text { (div) }\end{array}$ & $\begin{array}{c}\text { Percent } \\
\text { Swell } \\
(\%)\end{array}$ & $\begin{array}{c}\text { Elapsed } \\
\text { Time } \\
\text { (hrs) }\end{array}$ \\
\hline 259 & 0.00 & 0 \\
260 & 0.02 & 0.1 \\
262 & 0.07 & 0.3 \\
262 & 0.07 & 0.7 \\
263 & 0.09 & 3.1 \\
264 & 0.11 & 4.5 \\
268 & 0.20 & 19.3 \\
269 & 0.22 & 49.1 \\
270 & 0.24 & 74.0 \\
271 & 0.26 & 93.1 \\
271 & 0.26 & 119.8 \\
268 & 0.20 & 141.5 \\
269 & 0.22 & 164.3 \\
268 & 0.20 & 188.3 \\
265 & 0.13 & 216.5 \\
268 & 0.20 & 235.3 \\
266 & 0.15 & 259.3 \\
266 & 0.15 & 286.9 \\
267 & 0.17 & 311.0
\end{tabular}

$\left({ }^{*}\right)$

Wt. of Mold \& WS (gm)

Wt.of Mold (gm)

Wt. of WS

Boring No

Depth

Sample No

Visual Description

Test Type
Surcharge (Ibs)

Standard

na

eotechnics

Mold Volume (cc)

Wet Density $(\mathrm{gm} / \mathrm{cc})$

Wet Density (pcf)

Tare Number

Wt. of Tare \& WS (gm)

Wt. of Tare \& DS (gm)

Wt. of Tare $(\mathrm{gm})$

Wt. of Water (gm)

Wt. of DS (gm)

Water Content $(\%)$

Dry Density (pcf)

64.0

1122

NA

NA

HYD-AGG

Brownish Gray Agg

S. Height 4.58

1 div (in) 0.001

\begin{tabular}{cc} 
Initial & Final \\
\hline 9293 & 9958 \\
7113 & 7113
\end{tabular}

$2180 \quad 2845$

$2124 \quad 2127$

$1.03 \quad 1.34$

$64.0 \quad 83.5$

546.59

594

546.37

388.35

84.50

318.06

0.22

81.02

461.87

70.29

237.04

(*) Sample was removed from the submerged condition after the 164.3 hour reading.
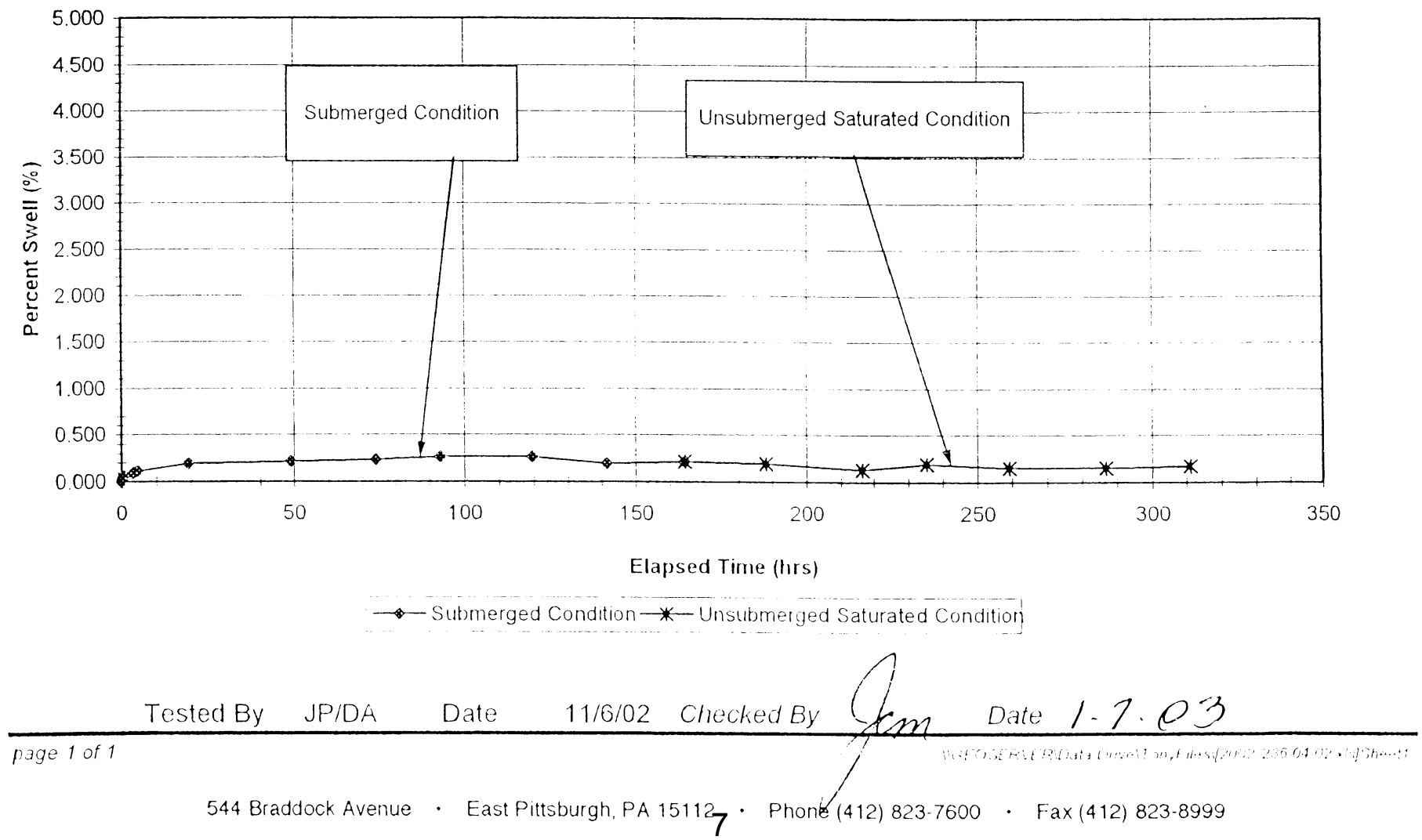
DCN: DS-\$33

DATE: $\quad 11 / 14 / 96$

REVISION: 1

Appendix A

PRELIMINARY RESULTS

\section{ONE DIMENSIONAL SWELL}

PTM 130

$\begin{array}{ll}\text { Client } & \text { Universal Aggregates } \\ \text { Client Reference } & \text { Swell Testing } \\ \text { Project No. } & \text { 2003-021-01 } \\ \text { Lab ID } & \text { 2003-021-01-02 }\end{array}$

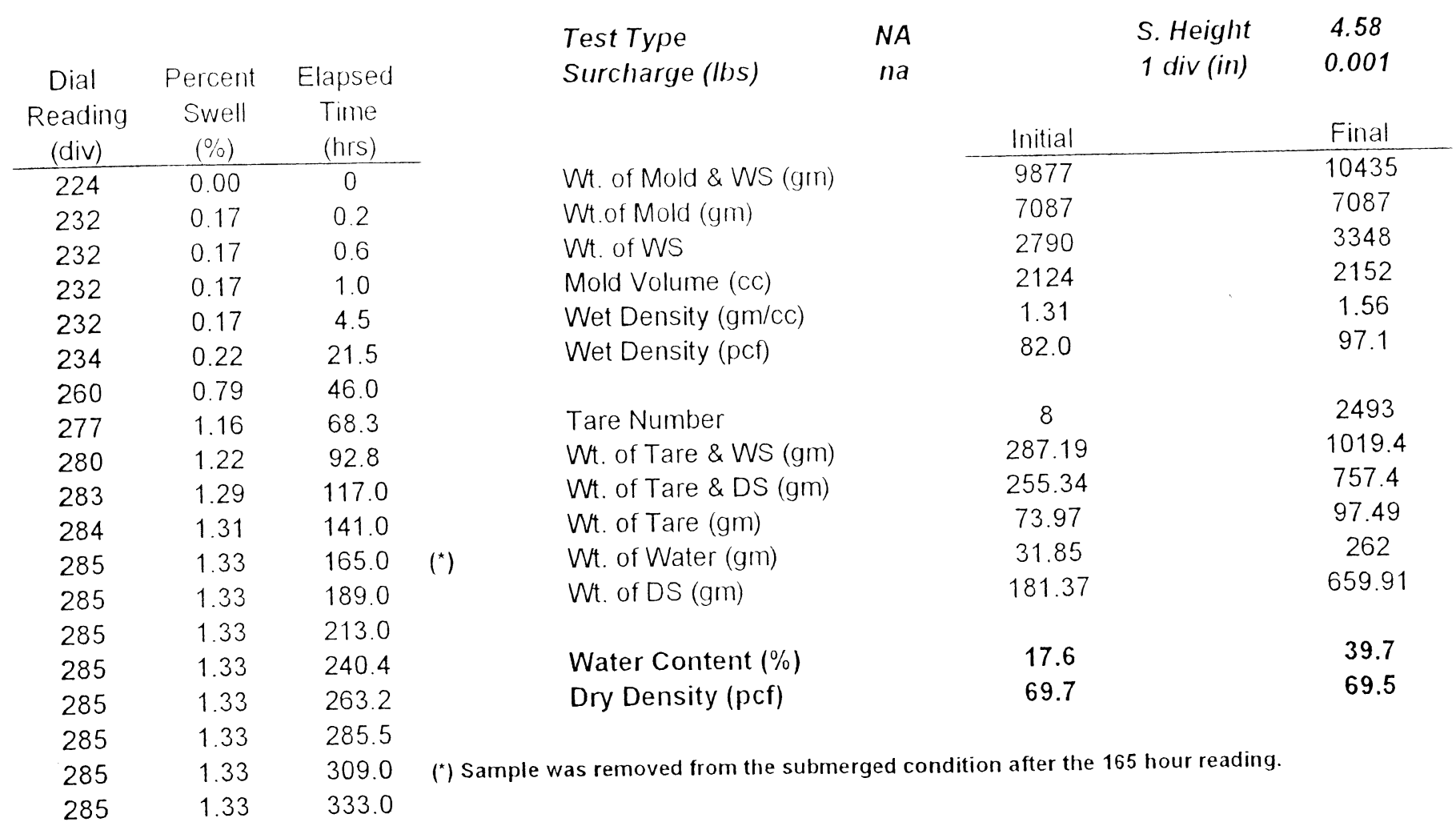

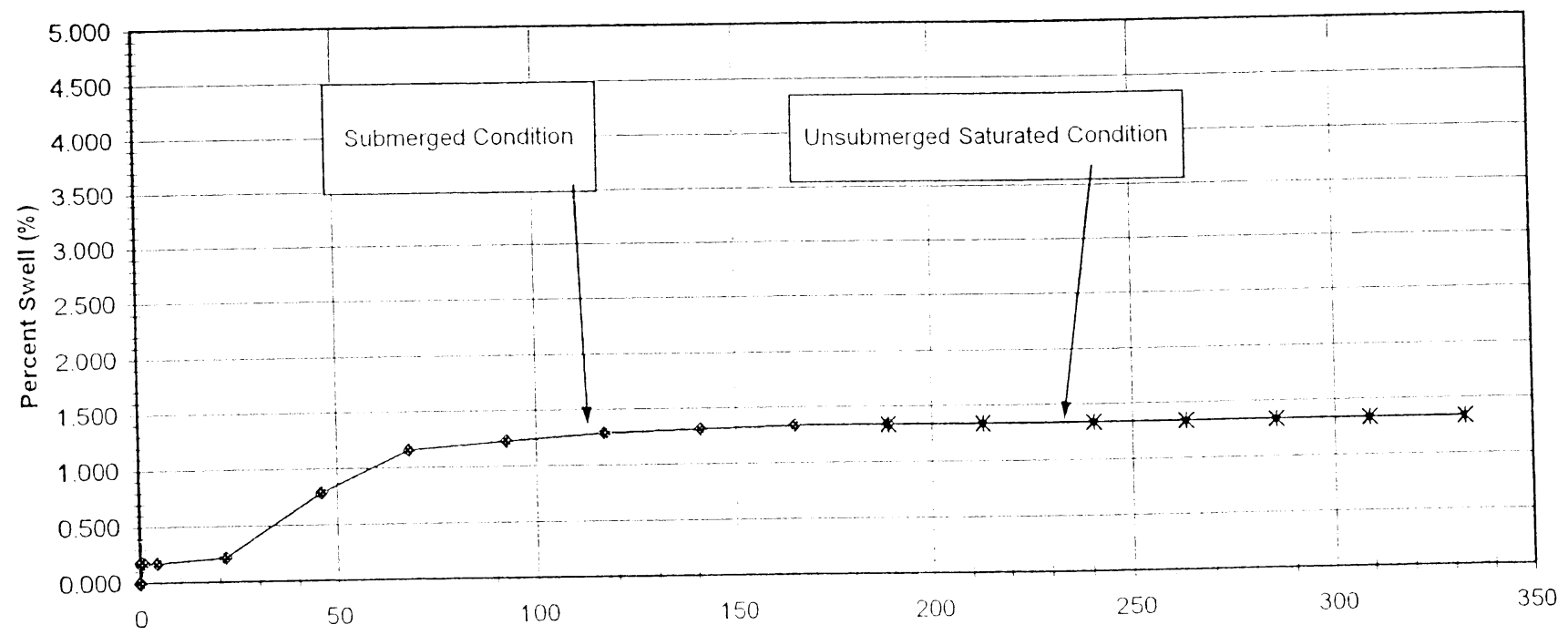

Elapsed Time (hrs)

$\rightarrow$ Submerged Condition- - Unsubmerged Saturated Condition

Tested By JP

Date

$1 / 22 / 03$ Checked By, . ()

Date $2 />103$

page 1 of 1

544 Braddock Avenue . East Pittsburgh, PA 15112. Phone (412) 823-7600 • Fax (412) 823-8999 
DCN: DS-S33

DATE: $\quad 11 / 14 / 96$

REVISION: 1

\section{ONE DIMENSIONAL SWELL}

PTM 130

Client

Client Reference

Project No

Lab ID

Dial Percent Reading Swell

$\frac{\text { (div) }}{38}$

$386 \quad 0.00$

386

386

386

386

390

390

390

391

391

391

391

391

391

391

391

391

391

391
Universal Aggregates

Swell Testing

2003-021-05

2003-021-05-02 $\begin{array}{ll}\text { Boring No. } & \text { NA } \\ \text { Depth } & \text { NA } \\ \text { Sample No. } & \text { PR-AGG-10 } \\ \text { Visual Description } & \text { Gray Agg. }\end{array}$

Test Type

Surcharge (lbs)

$\begin{array}{lll}\text { NA } & \text { S. Height } & 3.58 \\ \text { na } & 1 \text { div (in) } & 0.001\end{array}$

Wt. of Mold \& WS (gm)

Wt.of Mold (gm)

\begin{tabular}{ll} 
Initial & Final \\
\hline 9116 & \\
7078 & \\
2038 & \\
1659 & \\
1.23 & \\
76.7 &
\end{tabular}

Mold Volume (cc)

Wet Density $(\mathrm{gm} / \mathrm{cc})$

Wet Density (pcf)

A133

Tare Number

Wt. of Tare \& WS (gm)

13.2

Wt. of Tare \& DS (gm)

11.74

3.72

Wt. of Tare $(\mathrm{gm})$

1.46

Wt. of Water (gm)

8.02

\section{Water Content (\%)}

Dry Density (pcf)

18.2

64.9

$0.14 \quad 257.9$

$0.14 \quad 280.9$

$0.14 \quad 305.9$

(*) Sample was removed from the submerged condition after the 161.9 hour reading.

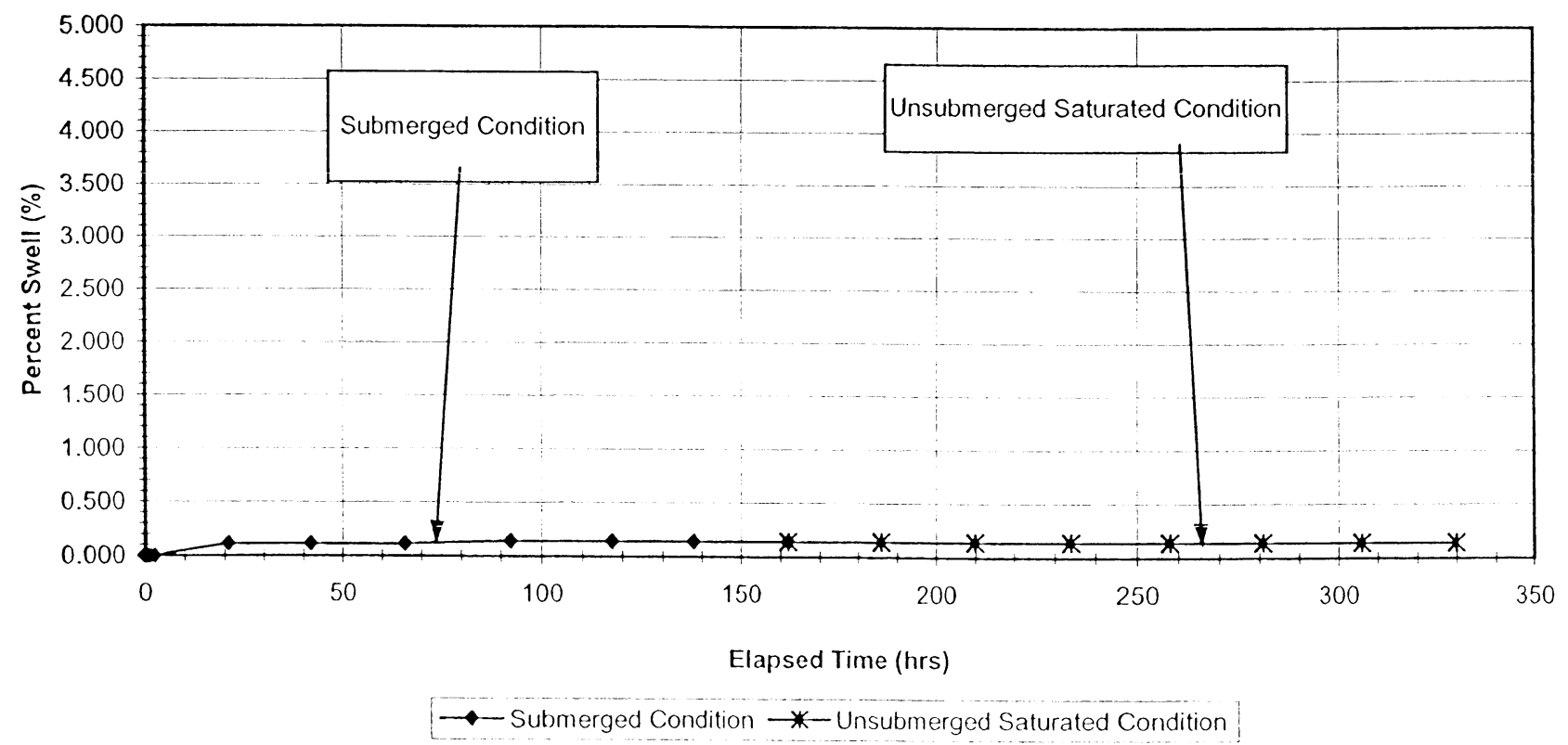

Tested By

Date

6/10/03 Checked By

Date 
Appendix A

DCN: DS-S33

DATE: $\quad 11 / 14 / 96$

REVISION: 1

\section{ONE DIMENSIONAL SWELL PTM 130}

Client

Client Reference

Project No.

Lab ID
Universal Aggregates

Swell Testing

2002-286-01

2002-286-01-03 $\begin{array}{ll}\text { Boring No. } & \text { NA } \\ \text { Depth } & \text { NA } \\ \text { Sample No. } & \text { JEA } \\ \text { Visual Description } & \text { Gray Aggregate }\end{array}$

Test Type

Surcharge (Ibs)

$\underset{n a}{\text { Standard }}$

S. Height 4.58

1 div (in) 0.001

WA. of Mold \& WS (gm)

Wt.of Mold (gm)

WA. of WS

Mold Volume (cc)

Wet Density $(\mathrm{gm} / \mathrm{cc})$

Wet Density (pcf)

Tare Number

Wt. of Tare \& WS (gm)

Wt. of Tare \& DS (gm)

W. of Tare $(\mathrm{gm})$

W. of Water (gm)

Wt. of DS (gm)

Water Content $(\%)$

Dry Density (pcf)

\begin{tabular}{cc} 
Initial & Final \\
\hline 9689 & 10175 \\
7007 & 7007 \\
2682 & 3168 \\
2124 & 2145 \\
1.26 & 1.48 \\
78.8 & 92.2 \\
& \\
1713 & 1131 \\
222.9 & 424.3 \\
209.39 & 327.4 \\
83.08 & 85.19 \\
13.51 & 96.9 \\
126.31 & 242.21
\end{tabular}

10.7

40.0

71.2

(*) Sample was removed from the submerged condition after the 161 and 496 hour readings.

$\begin{array}{lll}462 & 0.85 & 376.0 \\ 462 & 0.85 & 406.0 \\ 463 & 0.87 & 429.0 \\ 463 & 0.87 & 448.0 \\ 463 & 0.87 & 472.0 \\ 463 & 0.87 & 496.0 \\ 465 & 0.92 & 520.0 \\ 465 & 0.92 & 544.0 \\ 465 & 0.92 & 568.0 \\ 465 & 0.92 & 594.8 \\ 467 & 0.96 & 616.0 \\ 467 & 0.96 & 640.0 \\ 468 & 0.98 & 664.0\end{array}$

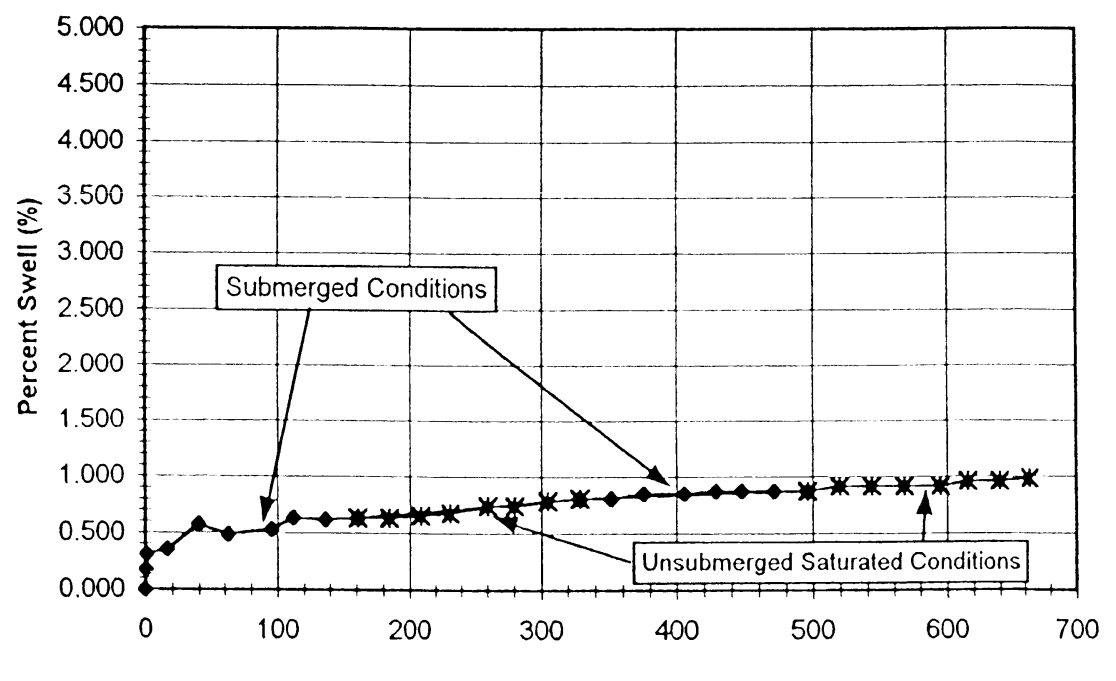

Elapsed Time (hrs)

$\multimap$ Submerged Condition $\rightarrow$ * Unsubmerged Saturatated Condition 
DCN: DS-S33

DATE: $\quad 11 / 14 / 96$

REVISION: 1

\section{ONE DIMENSIONAL SWELL}

PTM 130

$\begin{array}{ll}\text { Client } & \text { Universal Aggregates } \\ \text { Client Reference } & \text { Swell Testing } \\ \text { Project No. } & \text { 2002-286-03 } \\ \text { Lab ID } & 2002-286-03-02\end{array}$

Boring No. NA

Depth NA

Sample No. LEHIGH-LITE

Lab ID 2002-286-03-02

Visual Description Gray Aggregate

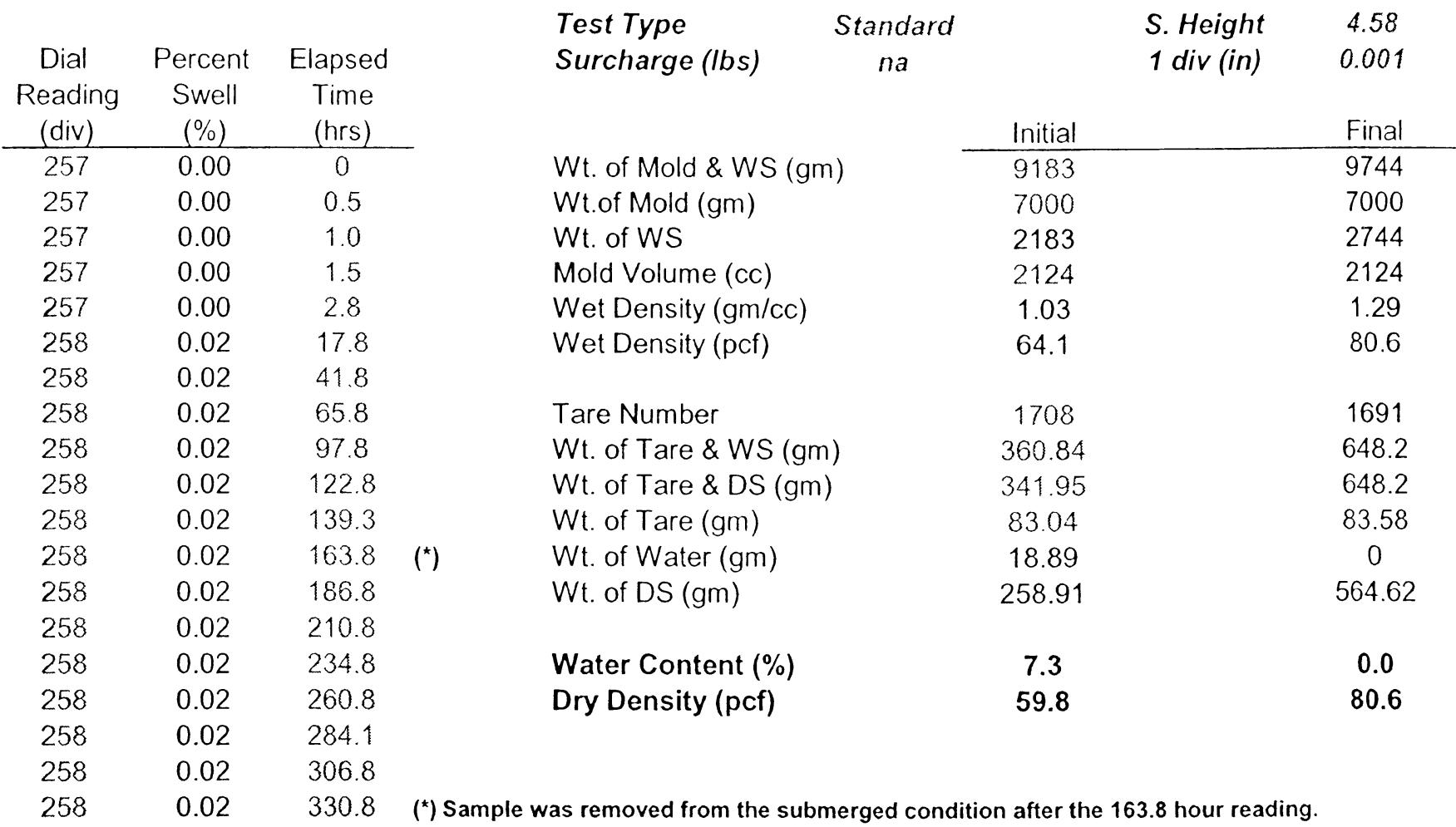

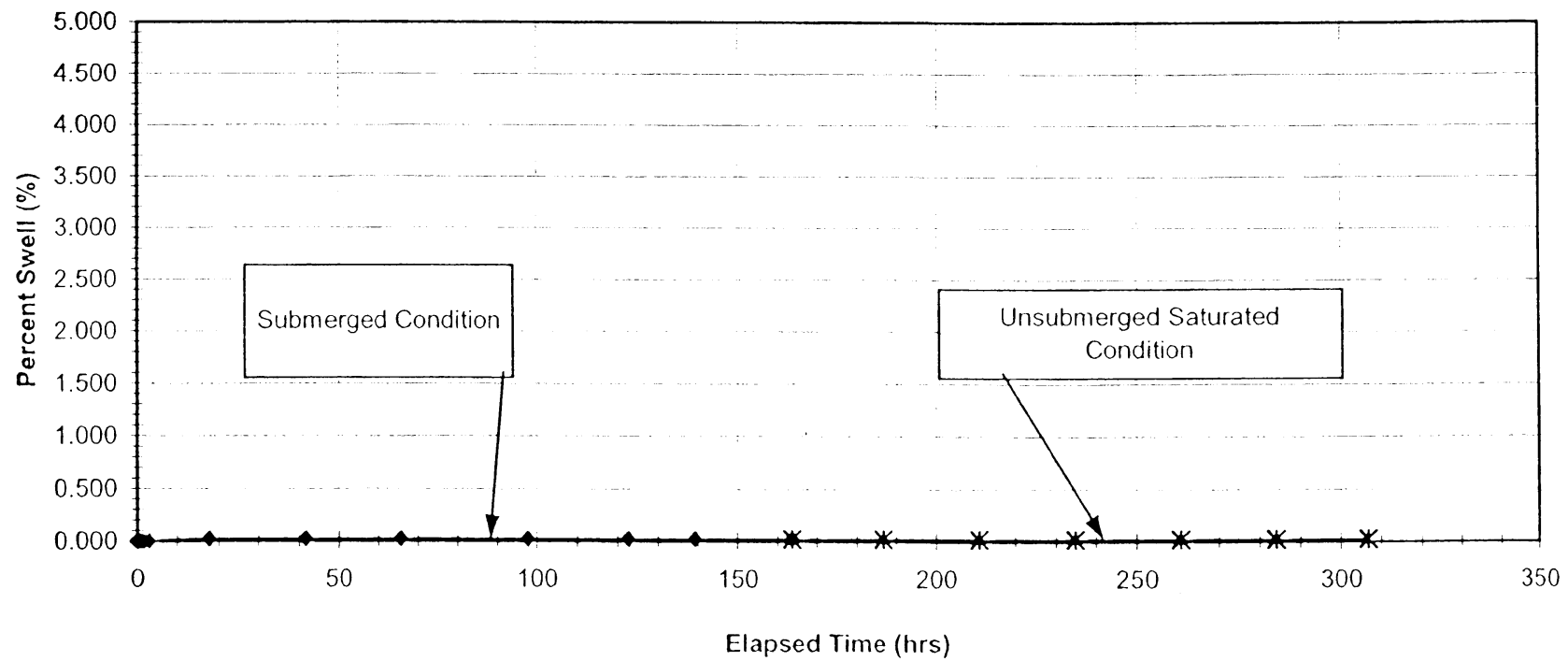

$\longrightarrow$-Submerged Condition $\rightarrow$-Unsubmerged Saturated Condition 
Appendix B. Swelling Tests - University of Kentucky Laboratory 
Appendix B

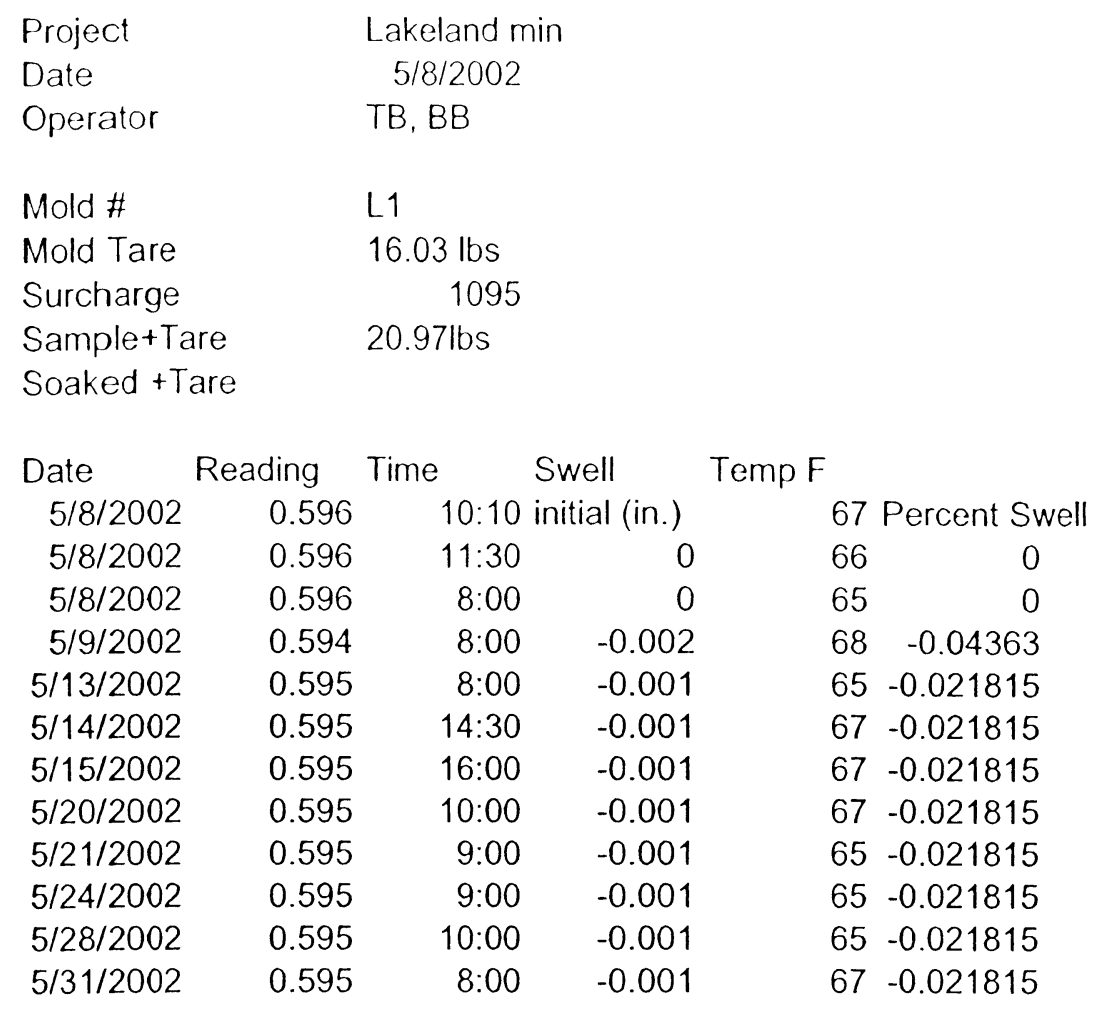




\section{Appendix B}

\begin{tabular}{|c|c|c|c|c|c|}
\hline $\begin{array}{l}\text { Project } \\
\text { Date } \\
\text { Operator }\end{array}$ & & $\begin{array}{l}\text { Lakeland } m \\
5 / 8 / 2002 \\
\text { TB, BB }\end{array}$ & & & \\
\hline Mold \# & & L2 & & & \\
\hline Mold Tare & & $16.30 \mathrm{lbs}$ & & & \\
\hline Surcharge & & 1191 & & & \\
\hline $\begin{array}{l}\text { Sample }+T a \\
\text { Soaked }+T\end{array}$ & & $22.41 \mathrm{lbs}$ & & & \\
\hline Date & Reading & Time & Swell & Temp F & Percent Swell \\
\hline $5 / 8 / 2002$ & 0.539 & $10: 25$ & initial (in.) & 66 & \\
\hline $5 / 8 / 2002$ & 0.541 & $11: 30$ & 0.002 & 66 & 0.04363 \\
\hline $5 / 9 / 2002$ & 0.541 & $8: 00$ & 0.002 & 68 & 0.04363 \\
\hline $5 / 13 / 2002$ & 0.541 & $8: 00$ & 0.002 & 65 & 0.04363 \\
\hline $5 / 14 / 2002$ & 0.541 & $14: 30$ & 0.002 & 67 & 0.04363 \\
\hline $5 / 15 / 2002$ & 0.541 & $16: 00$ & 0.002 & 67 & 0.04363 \\
\hline $5 / 20 / 2002$ & 0.541 & $10: 00$ & 0.002 & 67 & 0.04363 \\
\hline $5 / 21 / 2002$ & 0.541 & 9:00 & 0.002 & 67 & 0.04363 \\
\hline $5 / 24 / 2002$ & 0.541 & 9:00 & 0.002 & 65 & 0.04363 \\
\hline $5 / 28 / 2002$ & 0.541 & $10: 00$ & 0.002 & 65 & 0.04363 \\
\hline $5 / 31 / 2002$ & 0.541 & $8: 00$ & 0.002 & 67 & 0.04363 \\
\hline
\end{tabular}




\section{Appendix B}

\begin{tabular}{|c|c|c|c|c|c|}
\hline \multicolumn{2}{|l|}{$\begin{array}{l}\text { Project } \\
\text { Date }\end{array}$} & \multicolumn{2}{|c|}{$\begin{array}{l}\text { Birchwood minimum } \\
5 / 8 / 2002\end{array}$} & & \\
\hline $\begin{array}{l}\text { Mold \# } \\
\text { Mold Tare } \\
\text { Surcharge } \\
\text { Sample }+ \text { Ta } \\
\text { Soaked }+ \text { T }\end{array}$ & & $\begin{array}{l}\text { B1 } \\
16.23 \mathrm{lbs} \\
1192 \mathrm{~g} \\
20.62 \mathrm{lbs}\end{array}$ & & & \\
\hline Date & Reading & Time & Swell & Temp F & Percent Swell \\
\hline $5 / 8 / 2002$ & 0.401 & $9: 27$ & initial (in.) & 66 & 0 \\
\hline $5 / 8 / 2002$ & 0.397 & $10: 29$ & -0.004 & 66 & -0.08726 \\
\hline $5 / 8 / 2002$ & 0.397 & $11: 30$ & -0.004 & 67 & -0.08726 \\
\hline $5 / 9 / 2002$ & 0.396 & $8: 00$ & -0.005 & 68 & -0.109075 \\
\hline $5 / 13 / 2002$ & 0.396 & $8: 00$ & -0.005 & 65 & -0.109075 \\
\hline $5 / 14 / 2002$ & 0.396 & $14: 30$ & -0.005 & 67 & -0.109075 \\
\hline $5 / 15 / 2002$ & 0.396 & $16: 00$ & -0.005 & 67 & -0.109075 \\
\hline $5 / 20 / 2002$ & 0.396 & $10: 00$ & -0.005 & 67 & -0.109075 \\
\hline $5 / 21 / 2002$ & 0.3965 & 9:00 & -0.0045 & 67 & -0.098168 \\
\hline $5 / 24 / 2002$ & 0.397 & 9:00 & -0.004 & 65 & -0.08726 \\
\hline $5 / 28 / 2002$ & 0.397 & $10: 00$ & -0.004 & 65 & -0.08726 \\
\hline $5 / 31 / 2002$ & 0.397 & $8: 00$ & -0.004 & 67 & -0.08726 \\
\hline
\end{tabular}




\section{Appendix B}

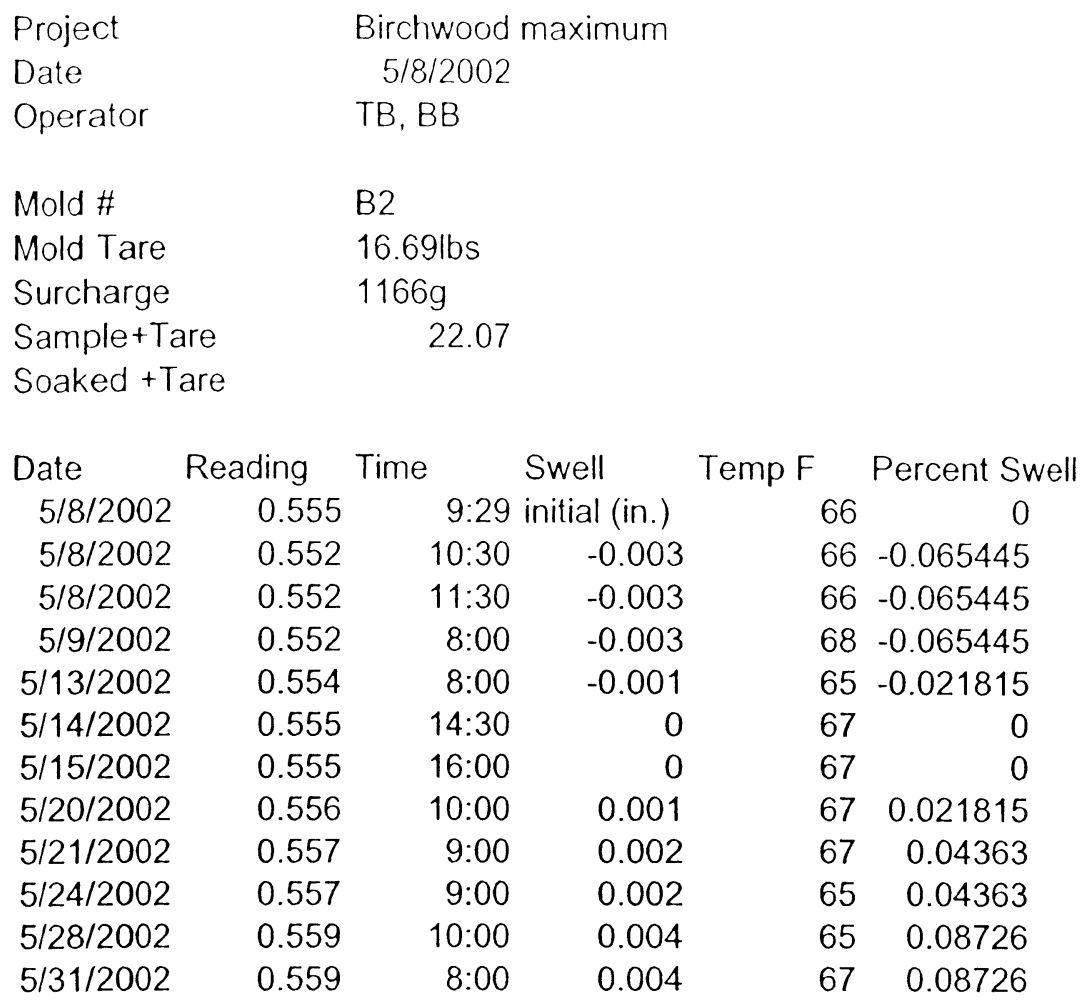

